$$
\text { Pontifícia Universidade C Católica }
$$

Ofélia da Conceição Machado Sagres

\title{
Hamlet no reino dos emojis: \\ a construção de sentidos em adaptações multimodais
}

Dissertação apresentada como requisito parcial para obtenção do grau de Mestre pelo Programa de Pós-graduação em Estudos da Linguagem do Departamento de Letras da PUC-Rio

Orientadora: Profa. Marcia do Amaral Peixoto Martins 


$$
\text { Pontifícia Universidade C Católica }
$$

\section{Ofélia da Conceição Machado Sagres}

\section{Hamlet no reino dos emojis: \\ a construção de sentidos em adaptações multimodais}

Dissertação apresentada como requisito parcial para obtenção do grau de Mestre pelo Programa de Pósgraduação em Estudos da Linguagem da PUC-Rio. Aprovada pela Comissão Examinadora abaixo.

Profa. Marcia do Amaral Peixoto Martins

Orientadora

Departamento de Letras - PUC-Rio

Profa. Marlene Soares dos Santos

UFRJ

Profa. Anna Stegh Camati

UNIANDRADE

Rio de Janeiro, 26 de junho de 2020. 
Todos os direitos reservados. A reprodução, total ou parcial, do trabalho é proibida sem autorização da universidade, da autora e da orientadora.

\section{Ofélia da Conceição Machado Sagres}

Graduou-se em Letras - Português/Inglês pela Universidade Federal do Rio de Janeiro (UFRJ) em 1989. Especializou-se em Literaturas de Língua Inglesa pela Universidade do Estado do Rio de Janeiro (UERJ) em 1995. É professora do Departamento de Inglês do Colégio Pedro II. É professora aposentada da Rede Municipal de Educação do Rio de Janeiro.

Ficha Catalográfica

Sagres, Ofélia da Conceição Machado

Hamlet no reino dos emojis: a construção de sentidos em adaptações multimodais / Ofélia da Conceição Machado Sagres; orientadora: Marcia do Amaral Peixoto Martins. - Rio de Janeiro: PUC, Departamento de Letras, 2020.

152 f.: il. color.; $30 \mathrm{~cm}$

1. Dissertação (mestrado) - Pontifícia Universidade Católica do Rio de Janeiro, Departamento de Letras.

Inclui referências bibliográficas.

1. Letras - Teses. 2. Adaptação. 3. Shakespeare. 4. Literatura infantil e juvenil. 5. Multimodalidade 6. Intermidialidade. 7. Ensino I. Martins, Marcia Amaral Peixoto. II. Pontifícia Universidade Católica do Rio de Janeiro. Departamento de Letras. III. Título. 
Para meus pais, Domingos (in memoriam) e Glória, e para minha irmã Teresinha. 


\section{Agradecimentos}

Quero agradecer a todos que me ajudaram nesta construção:

À Professora Marcia A. P. Martins pela paciência, orientação e apoio durante as aulas e na elaboração da dissertação.

Aos meus amigos e familiares pelo estímulo e suporte.

Às Professoras Anna Stegh Camati e Marlene Soares dos Santos e ao Professor Leonardo Bérenger Alves Carneiro por suas sugestões e comentários.

Aos professores do Departamento de Inglês do Colégio Pedro II, principalmente a Coordenadora Geral e os colegas do Campus São Cristóvão II, pelo incentivo e compreensão.

Aos professores do Programa de Pós-Graduação dos Estudos da Linguagem pela ajuda e dedicação. E aos meus colegas da PUC-Rio pelas ideias e conversas.

À Francisca Ferreira de Oliveira (Chiquinha) e aos demais funcionários da PUCRio pela assistência.

Às Professoras Charlotte Emmerich, Divanila e Rosemary dos Santos pela confiança.

Ao Colégio Pedro II pela licença capacitação oferecida. À CAPES e à PUC-Rio pelos auxílios concedidos.

A todos que autorizaram a utilização de seus trabalhos nesta dissertação.

O presente trabalho foi realizado com apoio da Coordenação de Aperfeiçoamento de Pessoal de Nível Superior - Brasil (CAPES) - Código de Financiamento 001. 


\section{Resumo}

Sagres, Ofélia da Conceição Machado; Martins, Marcia A. P. Hamlet no reino dos emojis: a construção de sentidos em adaptações multimodais. Rio de Janeiro, 2020. 152p. Dissertação de Mestrado - Departamento de Letras, Pontifícia Universidade Católica do Rio de Janeiro.

Esta dissertação tem como objeto de estudo uma adaptação da peça Hamlet, de William Shakespeare, intitulada srsly Hamlet ("falando sério, Hamlet", em tradução livre), de autoria de Courtney Carbone. A proposta da pesquisa é discutir, por meio da análise da adaptação, alguns procedimentos que, usados no processo de reescrita, visam não só manter alguns dos elementos do que se pode chamar de universo shakespeariano, mas também garantir que a peça do Bardo seja apreciada pelo público infantil e juvenil contemporâneo. A obra de Carbone, publicada em 2015 pela Random House Books for Young Readers, é o primeiro título da Série $O M G$ Shakespeare. A série é composta por quatro adaptações de peças de Shakespeare e busca levar a dramaturgia do poeta inglês para os leitores jovens de uma forma lúdica, sendo o seu principal diferencial em relação a outras adaptações voltadas para os jovens a apresentação dos textos no formato de mensagens de WhatsApp. Signos visuais e sonoros se sobrepõem nessas reescritas inovadoras das peças shakespearianas. A partir de uma perspectiva descritivista, este estudo averigua como a natureza multimodal e intermidiática de srsly Hamlet contribui para o processo de construção de sentidos e para a criação de imagens contemporâneas de Shakespeare e de Hamlet. Através da pesquisa das estratégias de adaptação empregadas (linguísticas e culturais), examina-se a influência das expectativas da cultura-alvo na manipulação da trama, da narrativa e da linguagem. Embora a adaptação de Carbone esteja, em princípio, voltada para o mercado literário e público anglo-americanos, espera-se que esta investigação sobre o processo de recriação de uma obra considerada canônica possa (i) contribuir para uma discussão mais ampla sobre os elementos que caracterizam, nos tempos atuais, as reescritas voltadas para a literatura infantil e juvenil impressa; e (ii) trazer novas possibilidades à reflexão sobre como o entrelaçamento entre qualidades 
intermidiáticas e a narrativa multimodal em uma obra afeta não só a criação de significados, mas também a experiência vivenciada pelos leitores.

\section{Palavras-chave}

Shakespeare; adaptação; reescrita; multimodalidade; intermidialidade. 


\section{Abstract}

Sagres, Ofélia da Conceição Machado; Martins, Marcia A. P. (Advisor). Hamlet in emojis kingdom: the processes of construction of meanings in multimodal adaptations. Rio de Janeiro, 2020. 152p. Dissertação de Mestrado - Departamento de Letras, Pontifícia Universidade Católica do Rio de Janeiro.

The research object of this master's thesis is an adaptation of William Shakespeare's Hamlet entitled srsly Hamlet, written by Courtney Carbone. The purpose of this study is to discuss, through the analysis of the adaptation, some procedures used in the rewriting process that aim not only to retain some elements of what may be called Shakespearean universe, but also to ensure that the Bard's Hamlet will be enjoyed by contemporary juvenile audiences. Carbone's work, published in 2015 under the Random House Books for Young Readers, is the first title of the $O M G$ Shakespeare Series. The series is made up of four adaptations of Shakespeare's plays and aims at bringing the English playwright's work to contemporary young readers in a playful way. One may say that the main gap between $O M G$ books and other written adaptations aimed at youths is the presentation of the text in WhatsApp-message format. Visual and aural signs overlap in these innovative rewritings of the Bard's plays. This research takes a descriptive perspective to go over how the intermedial and multimodal nature of Carbone's srsly Hamlet plays a part in the process of creating meaning and in the shape of contemporary images of Shakespeare and his Hamlet. Also, through the analysis of the adaptation strategies employed (linguistic and cultural), the influence of the target culture's expectations on the manipulation of plot, narrative and language is examined. Although Carbone's srsly Hamlet originally targets Anglo-American literary markets and audiences, this investigation of the process of recreation of a canonical-standing work may hopefully (i) contribute to a broader discussion of what characterizes adaptations directed at print children's literature in contemporary times; and (ii) add new possibilities to the reflections on how the intertwinement of intermedial qualities and multimodal narratives in literary works affects not only the construction of meaning, but also readers' experience. 


\section{Keywords}

Shakespeare; adaptation; rewriting; multimodality; intermediality. 


\section{Sumário}

1. Introdução

2. Embasamento teórico 22

2.1. Cultura como comunicação 22

2.2. Cultura como polissistema 24

2.3. Reescrita e patronagem 28

2.4. O conceito de adaptação 32

2.5. Intermidialidade e multimodalidade $\quad 37$

2.5.1. Iconicidade e transmodalidade 48

2.6. Caracterização da literatura infantil e juvenil 52

2.6.1. A literatura infantil e juvenil nos Estados Unidos 58

2.7. O teatro elisabetano 59

3. O Bardo no polissistema estadunidense 62

3.1. A patronagem 62

3.2. Vendas de livros 63

3.3. Shakespeare estadunidense $\quad 64$

3.4. O sistema educacional 70

3.5. Os emojis estadunidenses

4. História e narrativa: continuações e transformações 76

4.1. Elementos extratextuais e metatextos $\quad 77$

4.2. As possíveis influências nos Hamlets de Shakespeare e de Carbone $\quad 81$

4.3. Estrutura, tramas e subtramas 90

4.4. Personagens, espaço e tempo 93

4.5. Confluência de linguagens 103

5. Aspectos intermidiáticos e multimodais na adaptação 117

5.1. O palco elisabetano e a plataforma digital 117

5.2. A multimodalidade e a transmodalidade em srsly Hamlet 124 
6. Conclusão

7. Referências Bibliográficas

8. Anexo 1 - Atividades pedagógicas para a série 
Shakespeare doesn't mean: we mean by Shakespeare.

Terence Hawkes, Meaning by Shakespeare 


\section{Introdução}

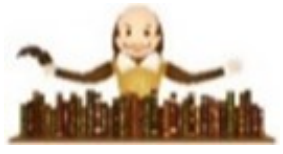

A proposta desta dissertação é analisar a obra srsly Hamlet (2015) de Courtney Carbone a fim de discutir como as estratégias empregadas contribuem para a classificação do texto como uma adaptação voltada para o público jovem e como os aspectos (inter)modais e intermidiáticos da obra colaboram para a construção não só de sentidos, mas também de imagens (representações) contemporâneas de William Shakespeare (1564-1616) e de suas peças.

Diante da escolha de tal obra como objeto de estudo de meu trabalho, a primeira indagação que pode ser feita é até que ponto é possível trazer algo novo relacionado ao mundo shakespeariano. Não é novidade afirmar que William Shakespeare é considerado um ícone da cultura ocidental, que é visto como a "Escritura secular" (BLOOM, 1994, p. 24). As criações do Bardo são as mais vendidas no mundo, ultrapassando 4 bilhões de cópias nos 400 anos após sua morte (LYNCH, 2014). Na verdade, o nome "Shakespeare" é tão reconhecido nos dias atuais que se tornou uma marca, um significante aberto, na cultura contemporânea. "Shakespeare é a Coca-Cola da cultura canônica"2 (LANIER, 2007, p. 93) e popular.

O que torna Shakespeare e suas criações imortais e atuais é justamente o fato de que suas produções são por si só recriações que, por sua vez, geram inúmeras e contínuas reescritas (FISCHLIN; FORTIER, 2000, p. 1). Essa capacidade de Shakespeare de inaugurar "formas de pensar e expressar-se capazes de produzir a sua própria diferença, aponta, em primeiro lugar, para a constante atividade adaptativa e intertextual de que sua obra vem sendo objeto desde o século XVII" (MEDEIROS, 2010, p. 62). Stephen Greenblatt (2004) destaca que o próprio Shakespeare pegava materiais que já estavam em circulação e os recriava. O estudioso também salienta que, além de se basear em obras de outros autores, o dramaturgo revisava extensivamente o próprio trabalho. Parte das revisões nas

\footnotetext{
${ }^{1}$ Tradução minha, assim como as demais citações extraídas de textos em língua inglesa, inclusive os fragmentos da obra srsly Hamlet, os quais traduzi mais livremente buscando obter efeito similar ao previsto para o texto-fonte.

2 "“[...], Shakespeare is the Coca-Cola of canonical culture, [...."
} 
peças feitas por Shakespeare podem ter sido causadas por mudanças de atores ou por demandas externas. Assim, é possível dizer que as peças do Bardo já eram fruto de recontextualizações desde o início.

Esse potencial para a reescrita, presente na própria criação de suas obras, pode remeter ao que Derrida (2014, p. 98) chama de iterabilidade, ou seja, "a um só tempo, [o texto] finca raízes na unidade de um contexto e, imediatamente, abre esse contexto não saturável para uma recontextualização". É essa propensão para continuar e se transformar, para transitar entre o canônico e o popular, para se ressituar em épocas e culturas distintas que posiciona Shakespeare na categoria de ícone.

Essa natureza moderna, mitológica e adaptável das obras do dramaturgo inglês se reflete no elevado número de obras publicadas. Além dos textos em língua inglesa, há inúmeras traduções, adaptações e apropriações. O gráfico abaixo indica, de uma maneira generalizada, o número de livros impressos, em várias línguas, cuja autoria é atribuída a Shakespeare:

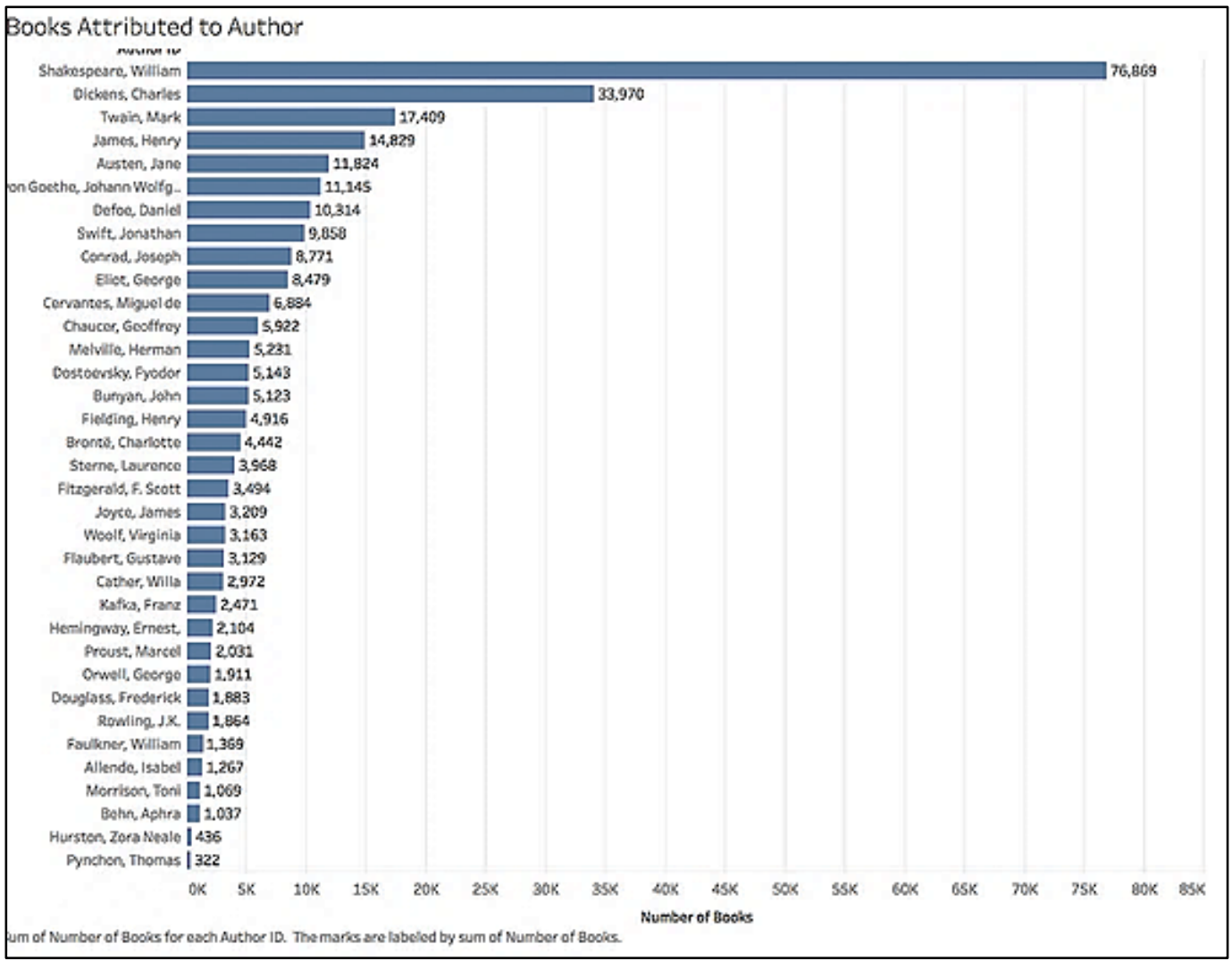

Gráfico 1- Posição dos autores - dados de Literary Lab's Popularity/Prestige Project Fonte: FREDNER, 2017 
Hamlet, em seus diferentes fólios e in-quartos, é a peça mais popular do Bardo a partir dos tempos modernos (ESTILL, 2015) e faz parte, de forma consciente ou não, do cotidiano ocidental. Segundo o estudioso Hugh Grady (2001, p. 270; 272), foi no século XVIII que Shakespeare passou a ser visto como um clássico literário, e suas obras começaram a gerar impacto fora da Grã-Bretanha. Hamlet, no final desse século, é tido como a criação excepcional do Bardo (FARLEY-HILLS, 1996 apud BRITLAND, 2013, p. 52). No Romantismo britânico, o prestígio do Bardo e de sua peça torna-se cada vez maior, "Shakespeare e Hamlet tornam-se homens prototípicos do gênio: pensativo, introspectivo, perturbado e profundo"3 (BRITLAND, 2013, p. 52). Foi essa visão romântica de genialidade e perfeição estética de Hamlet e de seu autor que perdurou no século XX e contribuiu para a sobrevivência do dramaturgo e de sua obra. Há produções e publicações de Hamlet em mais de 75 línguas, incluindo esperanto e klingon (ESTILL; JOHNSON, 2015). Dan Kopf (2016) também destaca que a história do príncipe dinamarquês é a quarta obra shakespeariana mais apresentada nos palcos estadunidenses (4,9\%), e a segunda em outras partes do mundo (5,9\%) desde 2006.

Jonathan Gil Harris (2010, p. 7) salienta que Shakespeare reconhecia a natureza escorregadia e não confiável da língua. De acordo com o estudioso, “o próprio Skakespeare é 'um manipulador de palavras' que se alegrava em qualquer oportunidade de virar uma palavra pelo avesso, e revelar outros sentidos inesperados"4. Hamlet, através da ambiguidade e fluidez de seu texto, claramente possibilita diferentes camadas de significação. No decorrer dos últimos quatro séculos, essa potencialidade de sentidos gerou não só diferentes níveis de interpretação, mas também variadas, e até mesmo opostas, recepções críticas. O professor William G. Holzberger (1975, p. 15) afirma que Hamlet é a obra literária mais discutida da história, não só por críticos literários, mas também por pensadores e escritores. A miríade de abordagens engloba desde a perspectiva neoclássica dos séculos XVII e XVIII até as abordagens românticas, estruturalistas, desconstrutivistas, queer, feministas, de gênero, pós-coloniais, mitológicas, psicanalíticas, materialistas e históricas dos séculos XIX, XX e XXI. É interessante

\footnotetext{
3 "Shakespeare and Hamlet become prototypical men of genius: pensitve, introspective, troubled and profound."

4 “[...] Shakespeare himself is 'a good wit' who delights in any opportunity to turn a word inside out and reveal other, unexpected meanings."
} 
destacar que o diálogo entre as abordagens críticas e as peças do Bardo podem ocasionar dois tipos de conexão. Por um lado, várias das reflexões teóricas surgidas tiveram suas inspirações nos textos do Bardo, ou seja, constituem uma "teoria [shakespeariana] que não é apenas sobre Shakespeare, mas obtém sua energia de Shakespeare" 5 (HARRIS, 2010, p. 4). Muitas teorias, por outro lado, "têm um profundo efeito nos modos e metodologias de se adaptar Shakespeare" 6 (SANDERS, 2006, p. 46).

Pode-se dizer, então, que a polissemia do texto da peça possibilita a recontextualização da obra e de sua crítica, reforçando, assim, a sua vocação para a contemporaneidade. Terence Hawkes destaca essa ausência de sentidos essenciais em Hamlet:

[...] Hamlet, assim como o Assassinato de Gonzago, não oferece um conjunto determinável de sentidos essenciais, mas exige ser visto como a oportunidade de vários significados que lhe são atribuídos em vários momentos no passado e no presente. ${ }^{7}$ (HAWKES, 1992, p.6)

A necessidade de pensar sobre diferentes "Shakespeares" e "Hamlets" produzidos pelas reescritas do século XXI surgiu da minha prática como professora de língua inglesa em escolas públicas do Rio de Janeiro. Como educadora, sempre considerei essencial destacar que a natureza linguística e comunicativa de meu trabalho está vinculada a componentes culturais. A comunicação entre culturas não pode ser vista apenas como o uso de códigos linguísticos, mas envolve signos verbais, comportamentos e coisas materiais. Essas três partes do processo comunicativo formam uma "linguagem silenciosa", inconsciente e automática (HALL, E.; HALL, M.,1990, p. 3), que precisa ser reconhecida para que haja uma verdadeira comunicação.

Como prática cultural, a literatura é uma parte essencial do processo de comunicação e de significação. Ao trabalhar com culturas diferentes da nossa, considero o conhecimento de suas produções e tradições literárias, ainda que

\footnotetext{
5 " $[\ldots]$ theory that is not just about Shakespeare but also derives its energy from Shakespeare."

6 " [...] many theories [...], have had a profound effect on the modes and methodologies of adapting Shakespeare."

7 "[...]Hamlet, like The Murder of Gonzago, offers no determinable set of essential meanings, it demands nevertheless to be seen as the occasion of a number of meanings which have been attributed to it at various moments in the past as well as the present."
} 
superficial, um elemento enriquecedor e esclarecedor. A dificuldade sempre residiu, no entanto, na maneira de possibilitar o acesso de alunos brasileiros do ensino fundamental a obras literárias em língua inglesa consideradas canônicas. Em 2016, por conta do quarto centenário da morte do Bardo, a busca por textos que permitissem o contato dos alunos com suas peças suscitou o questionamento a respeito de quais imagens de Shakespeare e de suas obras possibilitariam um encontro real com o mundo shakespeariano. Das dúvidas e descobertas da época surgiu o embrião para este estudo de caso.

A fim de tentar encontrar respostas para os questionamentos surgidos, optei por analisar uma das obras da série OMG Shakespeare, da Penguin Random House Children's Books. Até o presente momento, a série é composta por quatro adaptações do Bardo: srsly Hamlet (falando sério, Hamlet) e Macbeth \#killing it (Macbeth \# arrebentando), de Courtney Carbone, e YOLO Juliet (Você só vive uma vez Julieta) e A Midsummer Night \#nofilter (Sonho de Uma Noite \#sem filtro), de Brett Wright. Por conta do escopo de uma dissertação de mestrado, não seria possível fazer uma análise adequada das quatro adaptações. Escolhi, então, para meu estudo a obra srsly Hamlet. Essa opção baseou-se, além de uma preferência pessoal, no fato de o texto-fonte possuir algumas das passagens mais famosas da cultura ocidental. Considerei interessante verificar como essas passagens foram apresentadas na adaptação. Além disso, Hamlet de Shakespeare é uma das obras mais traduzidas e adaptadas. No período entre 1898 e 2013, por exemplo, houve mais de 50 adaptações cinematográficas da peça (FOLLOWS, 2014). Julgo importante a discussão sobre o que srsly Hamlet pode acrescentar às marcas Shakespeare e Hamlet, isto é, à imagem do Bardo e da peça como ícones canônicos e como instrumentos da cultura de massa. É também relevante a análise da relação entre a releitura artística de uma obra voltada para adultos e o que a sociedade espera em termos de literatura infantil e juvenil.

OMG Shakespeare, de acordo com o site da editora destinado a educadores e bibliotecários, busca, como um de seus propósitos, atuar como uma espécie de "elemento provocador" que "pode ser usado junto com o original para fisgar seus estudantes e ajudá-los a ver que as obras-primas de Shakespeare ainda são 
relevantes" ${ }^{\prime 8}$ (RHTEACHERLIBRARIANS, [2015?], [p. 1?] ). Esse comentário reflete um propósito educacional que se encontra geralmente embutido nas edições das obras de Shakespeare voltadas para faixas etárias jovens. Nessa tentativa de atrair leitores jovens, os autores da série, Courtney Carbone e Brett Wright, fazem uso da linguagem digital. Os textos são apresentados no formato de mensagens de WhatsApp e encontram-se repletos de emojis, fotos, acrônimos, siglas e abreviações.

Esta investigação, para fins de comparação com a adaptação, considera a obra The Arden Shakespeare: Hamlet, editada por Ann Thompson e Neil Taylor, como texto-fonte (Segundo Quarto). Em um primeiro momento, busco estabelecer as semelhanças e diferenças na estrutura (números de atos e cenas) e nos elementos da narrativa presentes na adaptação, ou seja, encontrar possíveis variações em termos de enredo (principal e secundários), personagens, tempo e espaço. No segundo momento, através da observação de algumas passagens consideradas marcantes, procuro refletir sobre a função da linguagem verbal (escrita e aural) e visual empregadas. Nesse exame dos aspectos linguísticos e visuais, espero identificar simplificações/reduções/ ampliações no que se refere a significantes e significados e discutir o papel desempenhado pelos emojis e demais recursos visuais na apresentação da linguagem e do teatro shakespearianos. Os resultados podem revelar não só a concepção que Carbone e a casa editorial têm a respeito de textos adaptados, mas também os elementos convencionalmente estabelecidos que caracterizam a literatura voltada para uma audiência infantil e juvenil.

Assim, ao analisar a obra srsly Hamlet, este estudo visa discutir as estratégias que caracterizam a obra de Carbone como uma adaptação narrativa multimodal e intermidiática, identificar as imagens de Shakespeare e de Hamlet que são construídas, revelar as alterações causadas pelas expectativas da sociedade em relação ao que caracteriza a literatura voltada para o público não adulto e analisar como tais concepções a respeito dessa categoria literária se relacionam a outros subsistemas culturais. Através da investigação proposta, espera-se identificar os possíveis interesses/motivações que levaram à introdução desse tipo de obra no polissistema literário estadunidense.

\footnotetext{
8 " [...] and can be used alongside the original text to hook your students and help them see that Shakespeare's masterpieces are still relevant."
} 
Segundo Richard Burt (2002, p.3), a relação entre Shakespeare e os meios de comunicação de massa costuma ser interpretada de duas maneiras. Ela parece favorecer uma democratização da cultura das classes socialmente privilegiadas e, ao mesmo tempo, pode gerar o empobrecimento das obras de Shakespeare. Ao discutir um Hamlet apresentado através de mensagens em uma das principais plataformas de comunicação, pretendo explorar as possíveis compatibilidades entre os diferentes meios envolvidos (teatro, livro e plataforma digital) e problematizar essa dualidade entre acesso e perda de valor.

Uma indagação que pode surgir ao se discutir o objetivo desse trabalho é qual a relevância de se analisar uma obra voltada, em princípio, para falantes de língua inglesa. A meu ver, o aspecto que se destaca em primeiro lugar é o da reescrita. As adaptações estão presentes em nosso cotidiano, mas, muitas vezes, elas apresentam um status subalterno alicerçado em preconceitos que valorizam o que é anterior (artes antigas são consideradas melhores) e que consideram adaptações como parasitas, já que são tidas como cópias (STAM, 2006, p. 21). Embora os Estudos da Adaptação tenham evoluído nas últimas décadas, poucas pesquisas abordam o papel do fator cultural nas adaptações (AMORIM, 2013, p. 25). Deve-se também destacar que a maioria das investigações ainda está centrada na transposição de obras escritas para o cinema e televisão. A pesquisadora Anna S. Camati (2013, p. 142) destaca, ao falar sobre as produções contemporâneas de Shakespeare, que elas "tendem a seguir o modelo fornecido pelo próprio Bardo, que costumava misturar e combinar gêneros, formas de arte popular e mídias variadas" ". Assim, o estudo de uma obra que envolve diferentes modalidades e meios não só contribui para a discussão sobre o processo de adaptação, mas também sobre o universo de Shakespeare que essa reescrita traz para o nosso século.

Um outro questionamento que pode ser levantado refere-se à escolha de uma adaptação que reproduz uma mídia que pode se tornar datada, ou seja, o texto no formato de mensagens de WhatsApp pode ter uma "vida" limitada. Em primeiro lugar, uma reescrita geralmente apresenta marcas não só do texto-fonte, mas da cultura e da época em que foi produzida. Ao analisar srsly Hamlet, acho importante discutir os elementos linguísticos, ideológicos, pedagógicos e econômicos que

\footnotetext{
9 "tend to follow the model provided by the bard who used to mix and combine multiple genres, popular art forms and media."
} 
caracterizam a cultura e o sistema literário infantis e juvenis do século XXI. Além disso, o WhatsApp parece ainda ter bastante fôlego. Segundo a revista Exame, o aplicativo é um dos mais usados no mundo para o envio de mensagens. No Brasil, são cerca de 120 milhões de usuários mensais (AGRELA, 2019). Nos Estados Unidos, 68.100.000 usuários de celulares empregaram o aplicativo para se comunicar em 2019. A expectativa para 2023 é de 85.800.000 (CLEMENT, 2019). Devo também mencionar que, de acordo com Rajewsky (2005), os estudos intermidiáticos englobam dimensões sincrônicas e históricas. A adaptação de Carbone possibilita a discussão sobre algumas qualidades que caracterizam diferentes mídias (teatro elisabetano, texto impresso e aplicativo de mensagens) e oferece uma oportunidade de comparação, em termos de características e de construção de sentidos, com outros meios de comunicação.

Esta dissertação é constituída por uma introdução, quatro capítulos de desenvolvimento do estudo e uma conclusão. O segundo capítulo da dissertação apresenta o embasamento teórico que permite a análise de srsly Hamlet da $O M G$ Shakespeare. Os conceitos de polissistemas de Itamar Even-Zohar (1990) e os de reescrita e patronagem de André Lefevere $(2014,2017)$ favorecem a análise da relação entre a adaptação e o sistema literário estadunidense. Já o modelo semiótico de Charles Peirce (1998), o quadro conceitual a respeito de adaptação de Linda Hutcheon (2013) e Julie Sanders (2006) e os conceitos de (inter)midialidade e de modalidade de Irina Rajewisky $(2005,2010)$, Werner Wolf (2002) e Lars Elleström $(2010,2013,2017,2018)$ constituem o fundamento para a discussão sobre as duas categorias de adaptação presentes na obra, ou seja, a de natureza (inter)semiótica e a de natureza midiática. Para se examinar o que caracteriza a literatura infantil e juvenil na época atual, são abordadas as propostas de estrutura universal para o desenvolvimento da literatura infantil de Zohar Shavit (1983, 1986, 1995). O que grande parte desses fundamentos têm em comum é o reconhecimento da necessidade do contexto para a construção do sentido. Assim, a cultura, vista como participante da formação discursiva, se entrecruza com o processo comunicativo e com seus modos de transmissão (mídias e modalidades).

No terceiro capítulo, busco fazer uma breve discussão sobre os contextos editoriais e culturais nos Estados Unidos na época da publicação da série $O M G$ Shakespeare (2015) e como tais fatores (ideológicos, econômicos e educacionais) 
podem ter interferido na própria construção da publicação. Também discuto a definição e o status dos emojis na sociedade do período (2014-2015) e a possibilidade de construção de significados a partir deles.

O quarto capítulo aborda as possíveis fontes da peça e alguns elementos narrativos que se mantiveram ou sofreram alterações em relação ao texto-fonte. Através dessa análise, tento discutir as estratégias adaptativas empregadas e como as expectativas relacionadas ao gênero e ao público-alvo podem ter interferido nas escolhas.

O quinto capítulo encontra-se dividido em duas partes. A primeira lida com questão da intermidialidade, ou seja, discute-se a relação entre a peça shakespeariana e as mensagens de WhatsApp que caracterizam a adaptação. Temse a transposição de uma mídia física, tradicional e híbrida (o teatro) para uma outra mídia tradicional (o livro), que busca representar um meio virtual e híbrido (mensagens através de um aplicativo). Debato até que ponto houve uma mudança real de plataformas na adaptação e como/se essa transposição pode interferir na adaptação da narrativa e na imagem que se tem da peça. A segunda parte do capítulo traz o aspecto semiótico do Hamlet de Carbone. Dentro da investigação do projeto gráfico da obra, estuda-se a natureza dos signos visuais presentes. Meu objetivo é examinar as características modais da adaptação e estabelecer uma relação com a proposta da série, ou seja, trazer uma obra de Shakespeare para o público infantil e juvenil onde o lúdico e o pedagógico possam interagir.

$\mathrm{Na}$ conclusão, procuro aprofundar a análise da adaptação a partir de suas características multimodais e intermidiáticas. A partir dessa exploração, tento apontar os prováveis elementos que revelam quais são as possíveis imagens de Shakespeare e de Hamlet que podem ser construídas a partir da leitura deste tipo de obra. Busco também analisar o possível papel dessas imagens no acesso e na divulgação da obra do Bardo. Além disso, destaco o papel que os possíveis resultados podem desempenhar no estímulo a novos estudos voltados para adaptações de obras literárias para crianças e jovens que envolvem apenas mídias impressas. 


\section{2 \\ Embasamento teórico}

Neste capítulo, apresento o quadro teórico que serve de suporte para minha análise.

\section{1}

\section{Cultura como comunicação}

Susan Bassnett e André Lefevere (1990, p. 11) destacam que as (re)escritas nunca são inocentes, ou seja, "sempre existe um contexto no qual a tradução acontece, sempre uma história da qual um texto emerge e para a qual um texto é transposto" ${ }^{10}$. Assim, para se analisar a obra srsly Hamlet, é preciso, em primeiro lugar, definir o conceito de cultura, entre os muitos existentes, que permeará o estudo.

Dentro de uma visão sistêmica de cultura, este trabalho baseia-se na noção de cultura de Edward Hall. Para Hall (1959, p. 51-53), a cultura esconde muito mais do que revela, inclusive para aqueles que nela estão inseridos. É uma série complexa de atividades aprendidas e compartilhadas no ambiente social; é comunicação em diferentes níveis. Segundo o antropólogo, a linguagem verbal é o sistema de mensagens mais técnico, mas existem outros, como tempo e linguagem visual. Dentro dessa perspectiva, o contexto e a produção de significados estão conectados, ou seja, "sem contexto, o código está incompleto, uma vez que ele abrange apenas parte da mensagem" 11 (HALL, 1989, p. 86). Para ele, a contextualização provavelmente envolve elementos internos (memória de experiências passadas e/ou aspectos fisiológicos) e externos (contextualização situacional e/ou ambiental).

Hall também destaca o fato de que a comunicação pode envolver elementos não verbais, e que o papel desses elementos na construção de sentidos varia. Essa variação na participação de fatores contextuais necessários para que a comunicação ocorra de forma produtiva pode ser alocada em um continuum em cujas extremidades se encontram a comunicação de alto contexto (o contexto é necessário

\footnotetext{
10 "There is always a context in which the translation takes place, always a history from which a text emerges and into which a text is transposed."

11 "Without context, the code is incomplete since it encompasses only part of the message."
} 
para a compreensão da mensagem) e a de baixo contexto (a maior parte da informação encontra-se explícita no código verbal). Segundo o antropólogo, embora não se possa fazer generalizações sobre aspectos culturais, a cultura estadunidense parece encontrar-se próxima ao baixo contexto na escala, ou seja, espera-se que a maior parte das informações esteja presente, de forma explícita, no código verbal (HALL, 1989, p. 91).

O papel do contexto na compreensão da mensagem em diferentes culturas é uma questão essencial neste estudo, uma vez que se busca analisar uma adaptação de uma obra literária. Considerando-se que toda obra de arte considerada "boa" é alto contexto (HALL, 1989, p. 92), ou seja, sua interpretação não se baseia apenas no texto verbal, mas também no ambiente físico, social e cultural, é importante se pensar no funcionamento de uma reescrita para um público de uma cultura distante no tempo e no espaço em relação ao texto-fonte. O acadêmico e dramaturgo britânico Michael Mangan (2014) ressalta que além de certas convenções linguísticas e teatrais terem mudado desde a época do Bardo, as interpretações geradas pelas palavras podem também não ser as mesmas. As práticas sociais, os costumes e hábitos da época atual ampliam e/ou modificam a significação do termo família, por exemplo. Mangan também evidencia o papel das alusões locais (pessoas e eventos) na construção do sentido. De acordo com o acadêmico, elas são capazes de fornecer uma nova camada de significação. A título de exemplo, ele cita a conversa entre Hamlet e Polônio antes da apresentação da peça "Assassinato de Gonzago" (III, ii, 94-102):

Hamlet My lord, you played once i'th'university, you say?

Polonius That did I, my lord, and was accounted a good actor.

Hamlet What did you enact?

Polonius I did enact Julius Caesar. I was killed i'th'Capitol Brutus killed me.

Hamlet It was a brute part of him to kill so capital a calf there. Be the players ready? ${ }^{12}$

(MANGAN, 2014, p. 95)

\footnotetext{
${ }^{12}$ HAMLET (Para Polônio) O senhor já representou certa vez na universidade, não?

POLÔNIO É verdade, senhor, e fui considerado um bom ator.

HAMLET Qual foi o seu papel?

POLÔNIO Representei Júlio César. Fui morto no Capitólio. Brutus me matou.

HAMLET Mas que coisa mais bruta trucidar um bezerrão tão capital. Os atores estão prontos?
}

(SHAKESPEARE, 2015, p. 95). Tradução feita por Lawrence Flores Pereira. 
Mangan (2014, p. 92-97) afirma que um dos possíveis níveis de interpretação do diálogo acima traz uma brincadeira entre os atores. Richard Burbage, o primeiro ator a assumir o papel de Hamlet, também atuou como Brutus na primeira montagem de Júlio César. Polônio era interpretado por John Heminges, que atuou como César na outra produção. Essa brincadeira pode ser vista como uma quebra da narrativa ficcional e como estratégia para indicar o que irá acontecer na peça. Para uma audiência contemporânea não profissional, essa camada interpretativa é dificilmente alcançada. Em srsly Hamlet, essa passagem foi eliminada, e o recurso metateatral encontra-se na própria escolha da mídia que é imitada (referência intermidiática) e em outros momentos do texto. A escolha pela eliminação pode estar relacionada à necessidade de redução do texto shakespeariano, mas também pode ter sido uma opção diante das dificuldades de manutenção das diversas esferas de interpretação.

\section{2 \\ Cultura como polissistema}

Essa visão da cultura como elemento comunicativo e formador de significados também apareceu nos estudos tradutórios. Conforme relata Theo Hermans (2014), a partir da metade da década de 1970 surgiu uma tentativa de se estabelecer um novo paradigma nos estudos da tradução literária. O grupo de teóricos que participaram da construção dessa nova abordagem da tradução compartilhavam de certos pressupostos básicos:

[...] uma visão de literatura como um sistema complexo e dinâmico; uma convicção de que deve haver uma contínua interação entre os modelos teóricos e os estudos de caso práticos; uma abordagem da tradução literária que seja descritiva, voltada para a cultura-alvo, funcional e sistêmica; e um interesse nas normas e restrições que governam a produção e recepção das traduções, na relação entre tradução e outros tipos de processamento de texto, e no lugar e papel das traduções tanto dentro de uma determinada literatura quanto na interação entre literaturas. ${ }^{13}$ (HERMANS, 2014, p. 10-11)

\footnotetext{
13 “ [...] a view of literature as a complex and dynamic system; a conviction that there should be a continual interplay between theoretical models and practical case studies; an approach to literary translation which is descriptive, target- oriented, functional and systemic; and an interest in the norms and constraints that govern the production and reception of translations, in the relation between translation and other types of text processing, and in the place and role of translations both within a given literature and in the interaction between literatures."
} 
Para se entender a percepção da literatura como um sistema ${ }^{14}$, é necessário discutir a Teoria dos Polissistemas desenvolvida por Itamar Even-Zohar, baseada nas ideias dos formalistas russos e dos estruturalistas checos. De acordo com o próprio teórico israelense, a Teoria dos Polissistemas começou a ser apresentada em seus trabalhos de 1969 e 1970, e surgiu pela necessidade de solucionar certas questões relacionadas à teoria da tradução e à estrutura histórica da literatura hebraica. Essa teoria concebe a cultura como um polissistema no qual o sistema literário é apenas um de seus constituintes. A noção de polissistema "torna explícita a concepção de um sistema tanto dinâmico quanto heterogêneo, em oposição a uma abordagem sincrônica" ${ }^{15}$ (EVEN-ZOHAR, 1990, p. 12). Além de não serem iguais, os sistemas ${ }^{16}$ encontram-se hierarquizados e em constante tensão. A principal característica da teoria dos polissistemas, assim como todas as demais teorias sistêmicas, é ser relacional. "Os elementos não são apenas considerados em relação a outros, mas derivam o seu valor da sua posição na rede" ${ }^{17}$ (HERMANS, 1999, p. 106-107). Assim, o poder reside na centralidade do polissistema. Em posições periféricas, sistemas ou elementos são tidos como fracos, marginais e, até mesmo, transgressores.

Partindo do pressuposto de que o valor de uma obra não é intrínseco, a canonicidade não é uma característica inerente ao texto/gênero/sistema, sendo determinada pelos círculos dominantes de uma cultura. Além disso, para a Teoria dos Polissistemas, não se pode considerar a existência de apenas um centro e uma periferia em um determinado sistema, uma vez que tais posições são hipotéticas (EVEN-ZOHAR, 1990, p. 14). Logo, deve-se falar em vários centros, e, portanto, em vários cânones.

É o constante desafio dos textos periféricos não-canonizados na busca por uma posição privilegiada que garante a evolução do sistema (EVEN-ZOHAR, 1990, p.16). Sem a competição, a mudança e a possível inovação (papel primário), haveria estagnação e o desaparecimento do (polis)sistema. Deve-se também deixar

\footnotetext{
${ }^{14}$ Nesta dissertação, os termos "sistema" e "polissistema" são intercambiáveis.

15 " [...] to make explicit the conception of a system as dynamic and heterogeneous in opposition to the synchronistic approach."

${ }^{16}$ Dependendo do contexto, os termos 'polissistema' e 'sistema' poderão ser empregados intercambiavelmente, assim como 'sistema' e 'subsistema'.

17 "Not only are elements constantly viewed in relation to other elements, but they derive their value from their position in a network."
} 
claro que o texto deixa de ser considerado o único e, em muitos casos, o mais importante, elemento do sistema. Ele funciona com outros fatores/sistemas em uma relação de interdependência (EVEN-ZOHAR, 1990, p. 33-34).

Ao falar sobre tradução, o estudioso israelense afirma:

[...] a própria questão sobre o que seja tradução não pode ser respondida a priori em termos de um estado idealizado fora de contexto e sem levar em conta aspectos históricos: deve ser determinada com base nas operações que governam o polissistema. De acordo com esse ponto de vista, a tradução não é mais um fenômeno cuja natureza e fronteiras sejam determinadas de uma vez por todas, mas uma atividade que depende das relações existentes dentro de um determinado sistema cultural. ${ }^{18}$ (EVEN-ZOHAR, 1990, p. 51)

Como já foi visto anteriormente, o polissistema cultural é constituído por um grupo de sistemas que se relacionam internamente e entre si de forma constante. $\mathrm{O}$ sistema literário, um dos sistemas constituintes, também é formado por inúmeros subsistemas. No centro do sistema, encontram-se os cânones (textos ou modelos textuais). O subsistema de textos traduzidos pode ocupar uma posição mais central ou mais periférica no sistema literário, dependendo de seu papel dentro daquela cultura.

A teoria de sistemas de Even-Zohar não só favoreceu uma abordagem da tradução voltada para a cultura-alvo (fortemente enfatizada por Gideon Toury) e funcional, mas "nos convida a pensar em termos de funções, conexões e interrelações. A contextualização dos fenômenos individuais é a chave" 19 (HERMANS, 1999, p. 33). Além disso, o texto-alvo deixa de ser visto apenas como o produto de escolhas linguísticas, mas também como o resultado de coerções sistêmicas de uma variedade de tipos (SHUTTLEWORTH, 2011, p. 199). Dessa forma, essa teoria propicia avanços nos estudos das relações e da função das reescritas dentro do sistema literário e da cultura-alvo.

A Teoria dos Polissistemas "é suficientemente abrangente para acomodar estudos descritivos da literatura tendo a cultura como unidade operacional"

\footnotetext{
18 "And even the question of what is a translated work cannot be answered a priori in terms of an ahistorical out-of-context idealized state: it must be determined on the grounds of the operations governing the polysystem. Seen from this point of view, translation is no longer a phenomenon whose nature and borders are given once and for all, but an activity dependent on the relations within a certain cultural system."

19 "[...] it invites us to think in terms of functions, connections and interrelations. Contextualization of individual phenomena is the key."
} 
(VIEIRA, 1996, p. 126). Além de abandonar visões essencialistas de fidelidade e equivalência no que concerne o estudo de textos traduzidos, a abordagem sistêmica de Even-Zohar e Toury também “preencheu a lacuna que surgiu na década de 1970 entre os estudos linguísticos e os literários, e forneceu as bases para os novos Estudos da Tradução interdisciplinares"20 (BASSNETT, 2002, p. 7).

O diagrama abaixo procura apresentar, de forma simplificada, a possível posição das adaptações para o público infantil dentro do polissistema estadunidense. Pode-se observar que a obra srsly Hamlet encontra-se no subsistema de adaptações que, por sua vez, está inserido no sistema de literatura infantil e juvenil e relaciona-se com o sistema de obras canonizadas voltadas para adultos, uma vez que o texto-fonte, isto é, Hamlet de Shakespeare, encontra-se nele. Constata-se também que a obra de Carbone perpassa pelos sistemas educacional, político, religioso e econômico. Em outras palavras, além do sistema literário, esses sistemas também influenciam e/ou interferem na criação, publicação e recepção da obra adaptada. É importante destacar que há pressões entre os subsistemas e entre gêneros/categorias/produtos em busca de posições mais centrais. Essas tensões estão representadas pelas setas no diagrama.

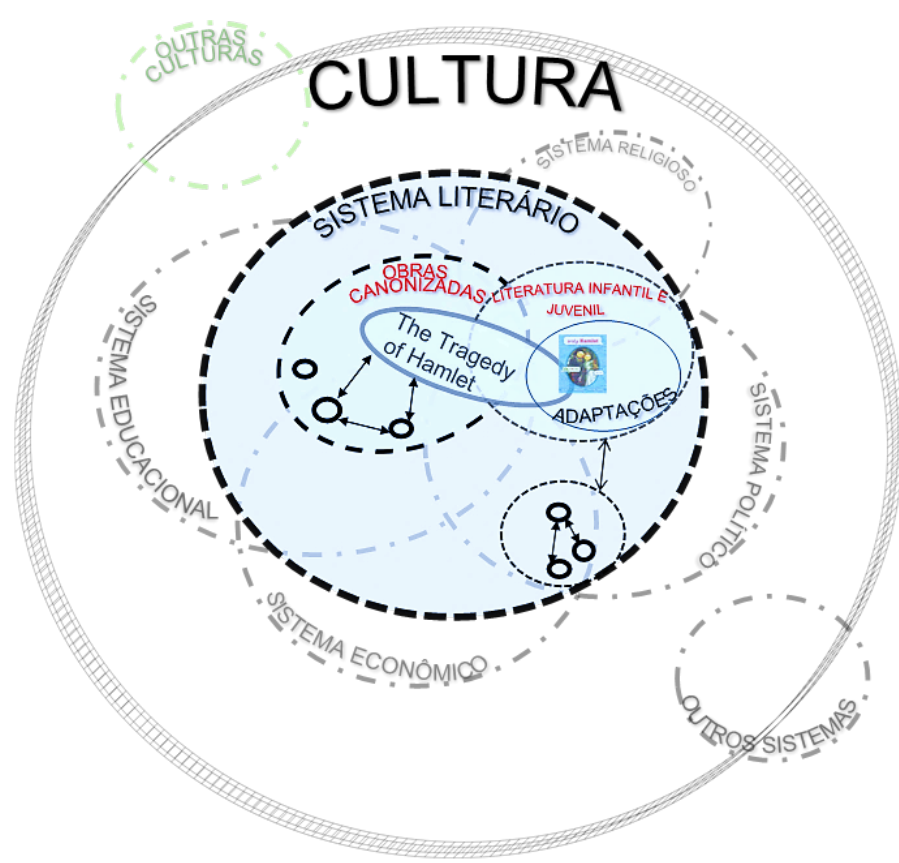

Diagrama 1 - Relações entre sistemas dentro de uma cultura Fonte: Elaborado pela autora desta dissertação (2020)

\footnotetext{
20 "Polysystems theory filled the gap that opened up in the 1970s between linguistics and literary studies and provided the base upon which the new interdisciplinary Translation Studies could build."
} 


\section{3}

\section{Reescrita e patronagem}

De acordo com visão sistêmica, o texto deixa de ser visto como um objeto linguístico que pode ser estudado isoladamente. $\mathrm{O}$ processo de reescrita, dentro dessa perspectiva, não pode ocorrer sem se levar em conta principalmente a culturaalvo. Susan Bassnett destaca que, em 1990, André Lefevere e ela publicaram a coletânea intitulada Translation, History and Culture, onde discutiam essa mudança de ênfase nos Estudos da Tradução. Segundo os dois autores, passou-se de uma fase formalista para uma que abarcava questões mais amplas, como contexto, história e convenções. Lefevere e Bassnett afirmavam que o objeto de estudo tinha sido redefinido, tornando-se então o texto inserido em uma rede de signos tanto da cultura-fonte quanto da cultura-alvo (BASSNETT,1998, p. 123).

Maria Tymoczko (2007, p. 81) afirma que uma importante contribuição para o impulso nos Estudos Descritivos da Tradução foi a teoria das reescritas, inicialmente chamadas refrações, do belga André Lefevere. É possível dizer que Lefevere baseia-se na teoria de polissistemas de Even-Zohar e na perspectiva descritivista enfatizada por Gideon Toury quando analisa a reescrita em sua interação com outros sistemas; quando parte da cultura-alvo para realizar seu estudo; e quando considera a reescrita a força motriz responsável pela evolução literária (LEFEVERE, 2017, p. 1). Contudo, Lefevere diferencia-se das ideias de Even-Zohar, às quais fez algumas críticas, ao dar maior ênfase a questões como "a interação entre sistema e ambiente, a organização interna do sistema e os mecanismos de controle" ${ }^{21}$ (HERMANS, 1999, p. 125).

Sistema, para o teórico belga, é um "termo neutro, usado para designar um conjunto de elementos inter-relacionados que por acaso compartilham certas características que os separam de outros elementos tidos como não pertencentes ao sistema" ${ }^{22}$ (LEFEVERE, 2014, p. 223-224). A cultura é o ambiente do sistema literário, e um influencia o outro.

\footnotetext{
21 “[...] Lefevere's greater emphasis on interaction between system and environment, on the system's internal organization and on control mechanisms."

22 " [...] a neutral term, used to designate a set of interrelated elements which happen to share certain characteristics which set them apart from other elements perceived as not belonging to the system."
} 
De acordo com Lefevere (2017), dois elementos, um interno e outro externo, que contribuem para a estabilidade do sistema literário através do controle do mesmo são, respectivamente, os profissionais (professores, reescritores etc.) e os agentes relacionados ao poder (patronagem). Cabe, em geral, aos profissionais o controle da poética, e aos agentes da patronagem, o controle da ideologia.

Com relação ao aspecto poetológico, Lefevere indica uma divisão em dois componentes. O primeiro relaciona-se aos recursos literários (gêneros, personagens-protótipos, situações, símbolos e motifs). O segundo componente refere-se às expectativas do sistema literário em relação ao papel da literatura na sociedade e influencia a escolha de temas (LEFEVERE, 2017, p. 20). Os elementos que constituem esses dois componentes podem sofrer alterações no decorrer do tempo.

No tocante à patronagem, o segundo elemento estabilizador do sistema literário, ela é constituída por três componentes que interagem: o ideológico (escolha da forma e do conteúdo), o econômico e o de status. Quando esses três aspectos são fornecidos pelo mesmo patrono/mecenas (reis, ditadores etc.), a patronagem é indiferenciada. Na patronagem diferenciada, o sucesso econômico não está necessariamente vinculado a fatores ideológicos ou ao prestígio. A patronagem, que pode ser composta por pessoas, grupos, instituições e/ou a mídia, tem como propósito manter a autoridade social. Seus agentes, em geral, controlam o acesso às obras literárias, já que a aceitação, canonização ou rejeição de uma obra literária não estão vinculadas a valores intrínsecos, mas a questões relacionadas a ideologia, poder, fama e recursos econômicos. Assim, os mecenas, que incentivam ou inibem a produção literária, impõem sua ideologia aos profissionais que irão selecionar/reescrever as obras dentro de determinada visão poética em uma determinada época. Como exemplo da atuação da patronagem, Lefevere apresenta os comentários de James H. Kavanagh sobre a relação de Shakespeare com seus diferentes patronos:

Como qualquer outro súdito real, ele [Shakespeare] tinha que agradar - ou pelo menos não desagradar - à soberana e sua Corte; [...]. Ele também teve que evitar a censura das autoridades londrinas, [...] que procuravam desculpas para fechar os teatros. [...] Shakespeare tinha de assegurar a aprovação de seu patrono na Corte nesse caso, o poderoso Lorde Chamberlain - que garantia proteção política à companhia teatral, e, literalmente autorizava o trabalho; ao mesmo tempo, ele tinha 
que manter o interesse de um público amplo constituído por comerciantes, artesãos e trabalhadores. Esse público, na verdade, era o principal suporte econômico da companhia, e estava ávido por representações concretas, e até mesmo sensacionalistas, que não podiam deixar de lidar com assuntos politicamente sensíveis. ${ }^{23}$ (KAVANAGH, 2002, p. 153)

Lefevere (2017, p. 6-7) aponta que a tradução, a historiografia, a antologização, a crítica, a edição e a adaptação caracterizam-se pelo mesmo processo básico de reescrita, sendo a tradução a mais reconhecida e potencialmente influente de todas essas modalidades. Todas essas formas são metatextos, ou seja, textos sobre outros textos, que envolvem questões ideológicas. Deve-se deixar claro que as distinções entre as diferentes formas de reescritas são porosas e que a função das mesmas, dentro dos Estudos Descritivos da Tradução, é definida "como o 'valor' atribuído a um item dentro de determinado sistema por conta da rede de relações na qual está inserido" ${ }^{24}$, referindo-se aqui à posição sistêmica (TOURY, 1995, p. 12).

Bassnett e Lefevere afirmam que todas as "reescritas, independentemente de suas intenções, refletem uma certa ideologia e uma poética e, como tal, manipulam a literatura para funcionar em uma determinada sociedade de uma determinada forma" ${ }^{25}$ (LEFEVERE, 2017, p. vii). A literatura, manipulada a serviço do poder, pode ser tanto inovadora, a partir do momento que introduz novas concepções e poéticas (dispositivos literários, gêneros e situações), como restritiva. As reescritas podem se enquadrar à ideologia e à poética de uma determinada cultura em uma certa época a fim de garantir o equilíbrio do sistema. Elas também podem assumir um papel transformador e subversivo, uma vez que "a luta entre poéticas rivais é frequentemente iniciada pelos escritores, mas são os reescritores que de fato entram

\footnotetext{
23 "Like any other royal subject, he had to satisfy - or at least not displease - the sovereign and her court; $[\ldots]$. He had also to avoid the censure of the London authorities, [...] who sought excuses to close the theaters. [...] Shakespeare had to keep favour with his court patron - in this case the powerful Lord Chamberlain - who afforded the company political protection , and, literally, licence to work; at the same time, he had to hold the interest of a broad public drawn from London's mercantile, artisanal and working classes. This audience, in fact, a lucrative market, was the company's main economic support, and was hungry for concrete, even sensationalistic, representations that could not help but touch on politically sensitive subjects."

24 "The term 'function' here is used in its semiotic sense, as the 'value' assigned to an item belonging in a certain system by virtue of the network of relations it enters into."

25 "All rewritings, whatever their intention, reflect a certain ideology and a poetics and as such manipulate literature to function in a given society in a given way."
} 
em combate, para vencer ou perder" ${ }^{26}$ (LEFEVERE, 2017, p. 29). Essa polaridade é essencial para a sobrevivência do sistema literário.

Um outro fato analisado por Lefevere (2017, p. 16) diz respeito à permanência das obras nos sistemas literários canonizados. O teórico salienta que universidades e outras instituições educacionais mantêm, em geral, os cânones vivos através da seleção de leituras para os cursos oferecidos. Segundo ele, a literatura canonizada nos Estados Unidos e no Reino Unido é mantida presente, de forma um tanto artificial, nas bibliografias indicadas pelos estabelecimentos educacionais, pois tais listas influenciam o que é editado e também reeditado. Lefevere também destaca a contribuição das reescritas para a sobrevivência dos textos-fonte. O teórico ressalta que o leitor não profissional está cada vez mais lendo reescritas (produzidas por tradutores, resenhistas e críticos) em vez de as obras originais que as inspiraram e acrescenta:

\begin{abstract}
No passado, assim como no presente, os reescritores criaram imagens de um autor, uma obra, um período, um gênero, às vezes até de toda uma literatura. Essas imagens coexistiam com as realidades com as quais elas competiam, mas as imagens sempre tendiam a alcançar mais pessoas do que as realidades correspondentes, e certamente elas continuam a fazer isso. ${ }^{27}$ (LEFEVERE, 2017, p. 4)
\end{abstract}

Essas imagens estão ligadas a fatores ideológicos e poetológicos na culturaalvo. Em muitos casos, essas imagens de autores e obras tornam-se mais reais do que o próprio original e alcançam um público bem maior.

Ao discutir os fatores que orientam as traduções e o modo como são recebidas, Lefevere destaca que as normas e/ou coerções a eles associadas, dentro de um sistema dinâmico, são circunstanciais. Como critérios, o teórico aponta, além dos relacionados à ideologia, à patronagem e aos aspectos poetológicos, os elementos que caracterizam o universo do discurso. Cada cultura possui suas características exclusivas, ou seja, o contexto da cultura-alvo não é normalmente semelhante ao da cultura-fonte, e muitos dos elementos de uma cultura não são

\footnotetext{
26 "The struggle between rival poetics is often initiated by writers but fought and won or lost by rewriters."

27 "In the past, as in the present, rewriters created images of a writer, a work, a period, a genre, sometimes even a whole literature. These images existed side by side with the realities they competed with, but the images always tended to reach more people than the corresponding realities did, and they most certainly do so now."
} 
admissíveis em outra. O processo interpretativo, portanto, também se encontra associado a certos conhecimentos, objetos, costumes e crenças, e é transitório. A atitude dos tradutores em relação ao "universo do discurso" do texto-fonte e do texto-alvo é

influenciada pelo prestígio do original, a autoimagem da cultura para a qual o texto é traduzido, os tipos de texto considerados aceitáveis naquela cultura, os níveis de dicção tidos como aceitáveis, o público implícito e os "roteiros culturais" que a audiência está acostumada ou disposta a aceitar. ${ }^{28}$ (LEFEVERE, 2017, p. 66)

Como visto acima, o público implícito desempenha um papel importante nas estratégias empregadas para traduzir os elementos do universo do discurso. Lefevere menciona, como exemplo, o fato de que certos aspectos do universo do discurso de Homero eram geralmente omitidos em traduções para jovens, principalmente em sociedades onde o livro era visto como ferramenta para a propagação de valores culturais (LEFEVERE, 2017, p. 70-71). Pode-se afirmar que essa visão da tradução como um processo contextualizado abarca outros tipos de reescrita, inclusive as adaptações. Ao se discutir as adaptações da série $O M G$ Shakespeare, a influência, na produção das obras, dos fatores externos e internos discutidos por Lefevere é claramente percebida. Se por um lado, as peças do dramaturgo inglês encontram-se inseridas nos cânones do sistema literário voltado para adultos, elas também apresentam uma forte conexão com o sistema educacional. Ao se adaptar tais obras para o público infantil e juvenil, consideramse não só as perspectivas ideológicas e poetológicas relacionadas ao sistema literário, mas também as produzidas pela visão que a sociedade tem a respeito das necessidades do público para o qual tais obras estão voltadas.

\section{4}

\section{O conceito de adaptação}

Ficou claro na discussão sobre sistemas e reescritas acima que "a adaptação, seja como produto ou como processo, não existe em um vácuo: ambos os casos têm

\footnotetext{
28 "This attitude is heavily influenced by the status of the original, the self-image of the culture that text is translated into, the types of texts deemed acceptable in that culture, the levels of diction deemed acceptable in it, the intended audience, and the 'cultural scripts' that audience is used to or willing to accept."
} 
um contexto - um tempo e um lugar, uma sociedade e uma cultura" 29 (HUTCHEON; O’FLYNN, 2013, p. xviii). Mesmo dentro da mesma cultura, mudanças são causadas por conta da passagem do tempo, por questões econômicas, morais e legais, e por avanços tecnológicos.

Embora as adaptações façam parte do cotidiano das pessoas desde a antiguidade, sua conceitualização ainda é difusa. Julie Sanders (2006, p. 3), por exemplo, elenca alguns termos associados a elas: "variação", "versão", “interpretação", "imitação", "sequência”, "hipertexto”, "palimpsesto", "reescrita”, "reavaliação" e outros. A teórica salienta, no entanto, que essa profusão de expressões reflete a riqueza e variedade que faz parte da essência das adaptações e apropriações, e seu estudo deve refletir tal fato.

Segundo Linda Hutcheon, a adaptação como produto é uma transcodificação específica de uma ou mais obras e, como processo, é a reinterpretação criativa e a intertextualidade palimpséstica (HUTCHEON; O’FLYNN, 2013, p.22). Trata-se de uma reescrita que claramente declara sua relação com outro(s) texto(s). A estudiosa canadense acrescenta:

Adaptação é repetição, mas repetição sem duplicação. E existem obviamente muitas intenções possíveis diferentes por trás do ato de adaptação: o anseio para consumir e apagar a memória do texto adaptado ou questioná-lo é tão provável quanto o desejo de prestar homenagem ao copiá-lo. ${ }^{30}$ (HUTCHEON, O’FLYNN, 2013, p. 7)

Hutcheon acrescenta que o fenômeno da adaptação, portanto, pode ser definido dentro de três perspectivas inter-relacionadas. A primeira, que considera a adaptação como produto, implica uma transposição de obra(s) para meios (mídias), gêneros e/ou molduras (contextos) diferentes. A segunda perspectiva lida com a adaptação como um processo duplo em que "o ato de adaptar sempre envolve uma (re)interpretação seguida de uma (re)criação; isso é chamado tanto de apropriação quanto de recuperação, dependendo da perspectiva" 31 . O terceiro ângulo que pode

\footnotetext{
29 "Neither the product nor the process of adaptation exists in a vacuum: they all have a context-a time and a place, a society and a culture."

30 "Adaptation is repetition, but repetition without replication. And there are manifestly many different possible intentions behind the act of adaptation: the urge to consume and erase the memory of the adapted text or to call it into question is as likely as the desire to pay tribute by copying."

31 "Second, as a process of creation, the act of adaptation always involves both (re-)interpretation and then (re-)creation; this has been called both appropriation and salvaging, depending on your perspective."
} 
definir a adaptação é o do processo de recepção (a experiência da repetição com variação) (HUTCHEON; O'FLYNN, 2013, p. 7-8).

Contudo, ainda para a teórica a conexão com outros textos não significa que a adaptação não seja uma obra independente ou que possa ser vista como uma imitação, algo secundário ou inferior, como geralmente acontece. Além disso, o fato de a adaptação possuir uma natureza múltipla (uma obra autônoma que, ao mesmo tempo, ecoa outras) não implica que a fidelidade ao texto-fonte deva ser o foco de análise dos estudos ou determinar o sucesso de uma adaptação. Adaptação não é cópia, é diálogo com outros textos (intertextualidade), e implica inúmeras intenções (homenagear, trazer outras perspectivas, suplantar o texto anterior ou valer-se do prestígio do texto-fonte). Hutcheon sugere que a avaliação de uma adaptação não deve, portanto, ser em termos de fidelidade, mas em relação à criatividade e habilidade de produzir um texto independente (HUTCHEON; O'FLYNN, 2013, p. 20-21).

É possível dizer que a adaptação pode envolver um procedimento de transposição (de um gênero para outro),de redução e/ou de amplificação (dando voz a outros personagens, por exemplo), mas também pode ser uma tentativa de dar relevância ou facilitar a compreensão do texto através de processos de aproximação e de atualização. As adaptações das obras de Shakespeare, assim como a de outros clássicos, em geral, têm esse objetivo (SANDERS, 2006, p. 18-19). Agrego a essa visão de adaptação, a noção apresentada pela estudiosa Marcia Martins (2014, p. 66), que também considera adaptações as reescritas voltadas para um tipo de público distinto do que era visado originalmente, as que promovem mudanças de cenário ou de época e as que envolvem a transmutação de signos verbais para outros tipos de signos e geralmente incluem mudanças de mídias.

O tema, para Linda Hutcheon, é, em geral, o elemento da história mais facilmente transposto nas adaptações para vários contextos, gêneros e mídias (HUTCHEON; O'FLYNN, 2013, p.6). Os elementos da narrativa (personagens, trama, tempo, espaço e foco) também são comumente adaptados, mas, normalmente, podem sofrer alterações significativas no processo. Tais mudanças podem gerar múltiplas (re)interpretações. As reescritas não só trabalham a narrativa de maneiras diversas, mas também podem apresentar diferenças em relação ao texto-fonte por conta das características do meio de expressão 
empregado. Segundo a teórica, essa mudança em termos de mídias e gêneros pode acarretar distintos modos de envolvimento do público, e até do adaptador, com a história. Os modos de engajamento propostos pela teórica formam uma tríade: o contar, o apresentar (performance) e o interagir (HUTCHEON; O'FLYNN, 2013, p. 22-44). Embora os três modos impliquem uma imersão por parte do leitor/audiência, esse envolvimento não ocorre da mesma maneira, nem com a mesma intensidade.

As adaptações geralmente, mas não necessariamente, envolvem mudanças em termos de mídias e, por conseguinte, alterações nos modos de participação do público e potencialidades/coerções em termos de codificação e de gêneros (convenção social). A compreensão das especificidades desses variados modos e das restrições e possibilidades de cada meio/mídia contribui para a análise da adaptação como produto e como processo.

No modo contar (impresso), a participação do público no texto é através da imaginação. Esse modo requer do público um trabalho conceitual de criação de sentido.

Por outro lado, o engajamento no modo performativo (adaptações para o cinema, televisão e teatro) se dá através da percepção direta (linguagens visual e sonora). Exige-se do público, desse modo, maiores habilidades para lidar com as diferentes modalidades envolvidas. As adaptações do modo contar para o apresentar (do texto escrito para a atuação) são as mais comuns. Pode-se dizer que o "modo performativo nos ensina que a língua não é o único modo de expressar significado ou de relacionar histórias" ${ }^{32}$ (HUTCHEON; O'FLYNN, 2013, p. 23). Hutcheon também destaca que, em termos semióticos, a mudança para o modo performativo implica, além do uso de símbolos (linguagem verbal), o emprego de ícones e signos indexais (materialização). A mudança entre esses dois modos pode significar não só uma mudança de mídia (com suas diferentes convenções), mas também de gênero e, com isso, alterar as expectativas do público (HUTCHEON; O'FLYNN, 2013, p. 45).

\footnotetext{
32 "The performance mode teaches us that language is not the only way to express meaning or to relate stories."
} 
O terceiro modo de engajamento é o interativo. A participação no texto é cinestésica (videogames e plataformas digitais). A imersão é imediata, física e mental.

Para Hutcheon, então, ao se fazer uma adaptação, deve-se levar em conta o fato de que cada modo de engajamento envolve uma determinada atitude mental do público/leitor e certas especificidades midiáticas e/ou de gênero textual.

Em uma análise inicial de srsly Hamlet, parece haver, em termos de engajamento do público, a passagem do modo performativo (peça de teatro) para o modo contar (narrativa impressa). Apesar de a adaptação imitar o leiaute de uma plataforma de mensagens instantâneas, não há a participação física (interativa) do espectador/leitor, já que a mídia técnica livro não é capaz de reproduzir todas as características físicas e potencialidades da plataforma digital. Contudo, o emprego de um gênero característico dessa plataforma, ou seja, mensagem via celular, propicia a passagem para o modo performativo. Em outras palavras, a presença de elementos de sistemas semióticos distintos (texto verbal escrito e texto imagético) associados a dimensões trans-sensoriais pode levar o leitor para o domínio da percepção direta. A passagem abaixo apresenta um conjunto de itens que possibilitam que o engajamento envolva não só a imaginação, mas também os sentidos (visão e audição).

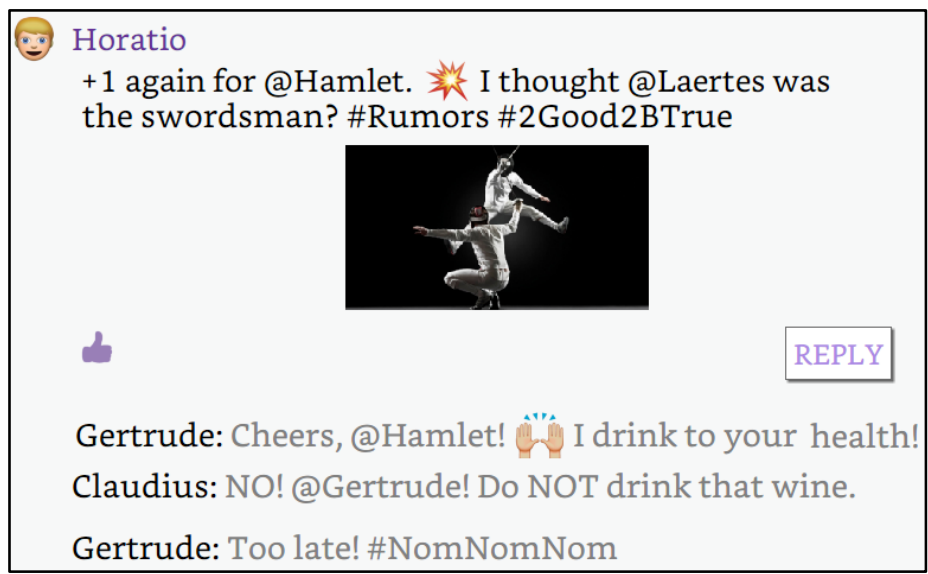

Figura 1 - Engajamento perceptual na adaptação ${ }^{33}$ Fonte: SHAKESPEARE; CARBONE, 2015, p. 95

33 Horácio: +1 para@Hamlet novamente. Eu pensei que @Laerte fosse o espadachim? \#Rumores\#Bomdemaisparaserverdade

Gertrudes: Saúde, @Hamlet! Eu bebo por sua saúde!

Cláudio: NÃO! @Gertrudes! NÃO beba aquele vinho.

Gertrudes: Tarde demais! \# GlugGlugGlug. 
Embora não seja possível fazer uso dos hyperlinks presentes (limitação em termos de mídia técnica), a percepção do leitor é alterada. A fotografia do duelo e o emoji "levantando as mãos" trazem gestos e movimento para o texto. O uso de palavras em caixa alta (aumento do tom), da onomatopeia ("NomNomNom") e do signo visual 2 relacionado a dois objetos (two e to) trazem o sentido da audição para percepção da mensagem. Logo, é possível afirmar que, de certo modo, o engajamento do leitor com a obra é o de apresentação, uma vez que algumas características dos personagens, das ações e dos espaços podem ser vistas.

Uma outra característica da adaptação importante para este estudo, e já salientada por Lefevere ao falar sobre a reescrita, refere-se à própria sobrevida de uma obra canonizada. As adaptações, em muitos casos, servem para reforçar um determinado cânone ao garantir, mesmo com novas reinterpretações, o interesse no texto-fonte (SANDERS, 2006, p. 97-98). Pode-se dizer que foi o processo de reescrita, visando atender públicos e leitores variados, que garantiu a sobrevivência de Shakespeare e de suas peças através do tempo e em sociedades distintas. O texto teatral, por ser um gênero discursivo multimodal, envolve a participação de diversos agentes em sua (re)construção. Além dos tradutores e adaptadores, merece destaque o papel dos editores, "responsáveis pelo desenvolvimento da imagem autoral de Shakespeare e pela forma e conteúdo dos textos que atualmente são considerados 'Shakespeare"' (SIPONKOSKI, 2014, p. 49-50), e dos produtores e diretores teatrais, responsáveis pela realização cênica do texto. Cabe também mencionar que as obras de Shakespeare e suas reescritas ocupam diferentes posições (canonizadas ou não) nos sistemas literários de diferentes culturas.

\section{5}

\section{Intermidialidade e multimodalidade}

O termo intermidialidade (Intermedialität) foi introduzido pelo acadêmico de Literatura Russa Aage Hansen-Löwe em 1983. O vocábulo referia-se às relações entre texto verbal escrito e imagens presentes, por exemplo, em poemas visuais (pattern poems) russos (RIPPL, 2015, p. 30). No entanto, assim como ocorre em relação à adaptação, esse conceito não está ligado a visões homogêneas. Para Irina O. Rajewsky (2005, p. 49), essa variedade de definições reflete a natureza heterogênea e ampla do conceito. A própria definição das mídias não é única e fixa, 
uma vez que se encontra associada a diferentes abordagens, contextos históricos e culturais, e mudanças tecnológicas. Pode-se dizer, portanto, que as fronteiras entre as mídias são estabelecidas não só por convenções, mas também por potencialidades/restrições operacionais e materiais.

Rajewsky destaca que, apesar de o fato de as mídias serem fenômenos culturais e não poderem ser consideradas puras, o estabelecimento de certas fronteiras e especificidades é essencial para os estudos intermidiáticos. Em uma conceituação mais genérica, a teórica define intermidialidade como as interações e interferências entre as mídias, o cruzamento de suas fronteiras. Dentro de uma concepção predominantemente sincrônica, Rajewisky, então, propõe, três categorias de intermidialidade. Tais categorias estão relacionadas a uma perspectiva literária e possibilitam a análise de produtos midiáticos com qualidades intermidiáticas distintas. A primeira delas é a transposição midiática, ou seja, um produto midiático é transformado em outra mídia. Como exemplos dessa categoria, é possível citar as adaptações cinematográficas (RAJEWISKY, 2005, p.51). A pesquisadora classifica essa concepção de intermidialidade como genética, já que a qualidade intermidiática, o critério de cruzamento entre as fronteiras midiáticas, refere-se à maneira como a sua configuração ou substrato é alterado (RAJEWSKY, 2010, p. 56). Assim, como nas adaptações, há um produto originado a partir de outro, mas ambos são autônomos.

Segundo Rajewsky, ao contrário da primeira categoria proposta, as outras duas divisões, a combinação midiática e a referência intermidiática, têm como objetivo uma intermidialidade intracomposicional (RAJEWSKY, 2010, p. 56). Segundo o teórico Werner Wolf, a intermidialidade intracomposicional caracterizase por "uma participação direta ou indireta de mais de um meio de comunicação na significação e/ou estrutura semiótica de uma obra ou complexo semiótico" 34 (WOLF, 2002, p. 17). Em outras palavras, o fenômeno intracomposicional das mídias não interfere apenas do processo de formação do produto, mas também no de sua significação.

A combinação midiática ou multimídia é a combinação de duas ou mais mídias convencionalmente distintas dentro de uma única obra em pelo menos uma 34 "[...] a direct or indirect participation of more than one medium of communication in the
signification and/or semiotic structure of a work or semiotic complex." 
ocasião. É o caso das peças teatrais, óperas, filmes e histórias em quadrinhos, onde há, pelo menos, duas mídias materialmente presentes contribuindo para a formação do produto. Nessa categoria, a intermidialidade é um conceito comunicativo e semiótico, uma vez que a integração entre as mídias se dá de forma física e contribui para a construção e significação do produto. A fusão dos componentes que caracterizam as mídias torna-se uma especificidade do próprio gênero.

A última divisão apresentada por Rajewsky, referências intermidiáticas, envolve, dentro de uma única mídia, a evocação ou imitação de outra(s) mídia(s) através da menção e/ou do emprego de elementos ou estruturas que são considerados característicos das mídias reproduzidas. Wolf salienta que, ao contrário da plurimidialidade (combinação midiática), a referência intermidiática é uma forma de intermidialidade intracomposicional onde há uma homogeneidade semiótica e midiática. O teórico ressalta que esse tipo de intermidialidade pode apontar para uma única obra ou para um sistema inteiro. Assim como Rajewsky, Wolf apresenta dois tipos de referência. A referência explícita (evocação, segundo Rajewsky) é claramente perceptível nas mídias verbais. Ela ocorre quando se discute uma obra ou mídia, quando há menção a ela ou quando há a presença de representantes de outras mídias (um ator como personagem de um romance por exemplo). Na referência implícita (imitação), por outro lado, os significantes da obra são afetados pelos da mídia a que se referem e essa alusão envolve algum tipo de iconicidade (WOLF, 2002, p. 23-25). Deve ficar claro, contudo, que, devido a certas especificidades de cada mídia, a presença de uma outra mídia é apenas aparente, já que não é possível usar ou reproduzir todos os sistemas e componentes de uma mídia convencionalmente distinta (RAJEWSKY, 2005, p. 53-55). Como já foi dito anteriormente, essa estratégia de referência contribui para a construção de sentido da obra. É preciso também ressaltar o fato de que as referências intermidiáticas dependem da percepção clara das diferenças entre as mídias envolvidas e podem ser combinadas de várias formas. Ao associarmos o modelo proposto por Rajewsky com nosso estudo, é possível afirmar que as obras da série $O M G$ Shakespeare podem ser vinculadas a duas categorias. As adaptações de Carbone e Wright podem ser vistas como o resultado de uma transposição midiática, uma vez que são textos narrativos impressos (livros) provenientes de uma peça de teatro (roteiro cênico). Contudo, considero que elas são primordialmente 
referências intermidiáticas. A plataforma do aplicativo de troca de mensagens não está presente fisicamente, ou seja, não há combinação de mídias, mas sua imitação pode contribuir para as possíveis recepções das adaptações. A passagem abaixo é um claro exemplo. É possível identificar quatro hyperlinks. Os três primeiros são textos verbais visíveis que indicam o conteúdo da página de destino. O último é um botão com texto verbal e envolve uma maior participação, já que ele deve ser clicado quando se deseja escrever uma resposta. Na realidade, esses acessos a outros documentos ou páginas não existem porque não há tecnologia digital, ou seja, a materialidade do livro não permite que o leitor abra documentos que estão em outros lugares ou execute as ações sugeridas. O modo de interação do público parece continuar a ser o contar, próprio dos livros.

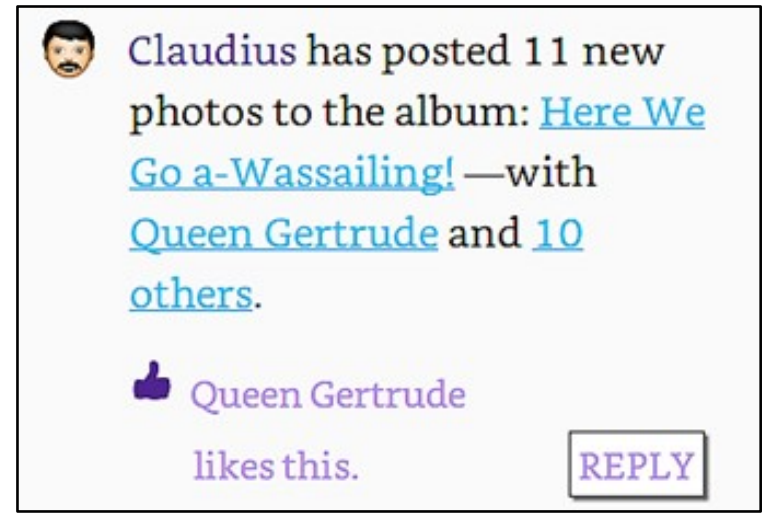

Figura 2 - Hyperlinks ${ }^{35}$

Fonte: SHAKESPEARE; CARBONE, 2015, p. 22

O professor sueco Lars Elleström traz uma proposta que busca aproximar os estudos da adaptação e as abordagens intermidiáticas e multimodais. Elleström (2017c, p. 17) afirma que "uma mídia deve ser entendida de forma ampla como o estágio intermediário da comunicação", uma ponte para mediar informação e diversão. Para o teórico, "mediar" é o pré-requisito físico para a representação (concepção semiótica) das mídias. Segundo ele, todas as mídias são intermidiáticas e multimodais, uma vez que "são compostas por características básicas múltiplas e só são compreendidas em relação a outros tipos de mídia"36 (2014, p. 2). Em seu

\footnotetext{
${ }^{35}$ Cláudio postou 11 fotos novas no álbum: Aqui vamos nós passar a noite a beber! - Com Rainha Gertrudes e 10 outros.

- Rainha Gertrudes gosta disso.

36 "All media are multimodal and intermedial in the sense that they are composed of multiple basic features and are understood only in relation to other types of media."
} 
projeto para analisar o fenômeno intermidiático, Elleström apresenta duas categorias que englobam não só a transferência de características semióticas e cognitivas, mas também aspectos materiais e sensórios: a combinação e integração de mídias e a transformação e transferência. A primeira categoria intermidiática aproxima-se do conceito de combinação midiática de Rajewsky. Já a segunda categoria, que envolve alterações em diferentes graus, pode ser dividida em transmidiação (mediação de conteúdos e/ou formas já mediados por outras mídias técnicas) e representação (processo de significação em que um meio/produto evoca outro tipo de meio/produto na recepção cognitiva e perceptual). Um romance transferido para um filme pode ser um exemplo de transmidiação. Já a fotografia de uma apresentação de dança pode ser considerada uma representação, uma vez que representa tanto o conteúdo quanto a forma da mídia fonte e gera um certo tipo de interpretação. Pode-se dizer, assim, que a transmidiação baseia-se no aspecto material das mídias, enquanto a representação fundamenta-se no fator semiótico (ELLESTRÖM, 2017d).

Apesar de esta dissertação basear-se nas categorias intermidiáticas propostas por Rajewsky, merece destaque o conceito de transmidiação apresentado por Elleström. A noção de que o potencial significativo sofre alterações na transmidiação em função das diferenças entre mídias pode ser associada às transformações trazidas pelas adaptações. O próprio teórico aponta para a tendência de se inserir o conceito de adaptação nos estudos das transformações midiáticas e de se considerar a adaptação como a transmidiação de um produto midiático específico (obra) em outro (ELLESTRÖM, 2013a, p. 129). Pode-se dizer, assim, que a série $O M G$ Shakespeare é uma adaptação transmidiática, resultado da transformação de uma peça teatral em uma estrutura impressa. A compreensão do processo de criação e significação dessas obras envolve não só a discussão sobre os elementos da história e da narração transpostos, bem como o papel das estratégias transmidiáticas e das relações intermidiáticas.

Elleström registra a existência de quatro aspectos transmidiáticos interrelacionados que são essenciais para a mediação e que formam a natureza de cada uma das mídias. Todas as mídias e produtos midiáticos resultam, portanto, de combinações específicas dos modos dessas quatro categorias. São as diferenças em 
termos de modalidades entre as mídias que permitem transformações e novas criações.

Essas quatro modalidades latentes encontram-se em uma escala que vai do tangível ao perceptual e ao conceitual (mental). As três primeiras (a modalidade material, a sensorial e a espaçotemporal) referem-se às condições básicas para que o produto midiático seja recebido e para que a comunicação ocorra, ou seja, para que exista mediação. Elas são chamadas pré-semióticas porque estão relacionadas às características midiáticas conectadas à significação, mas não são qualidades semióticas em si mesmas (ELLESTRÖM, 2017c, p. 38).

A primeira modalidade pré-semiótica, a material, é apresentada por Elleström como "a interface física latente do meio" 37 (2010b, p. 17). Segundo o teórico sueco, o traço material das mídias pode apresentar grandes variações, contudo, é possível distinguir três modos (variantes) de modalidade material: corpos humanos, outras materialidades de caráter demarcado (como superfícies planas e objetos tridimensionais) e manifestações materiais menos demarcadas (ondas de som e diferentes tipos de projeções de luz, por exemplo) (ELLESTRÖM, 2010b, p. 17). Em relação à qualidade material das adaptações de $O M G$ Shakespeare, pode-se afirmar que são superfícies planas estáticas (folha de papel ou tela do computador).

Para o teórico, a modalidade sensorial é constituída pelos "atos físicos e mentais de percepção das interfaces midiáticas através das faculdades sensoriais" 38 (ELLESTRÖM, 2010b, p. 17). Essa modalidade é um pré-requisito para as duas seguintes, uma vez que a percepção sensorial é vital para a cognição. Os principais modos dessa modalidade são os próprios sentidos. Na série da Penguin Random House, por exemplo, pode-se afirmar que há um predomínio do modo visual. Além do texto verbal visual, há o uso de imagens estáticas (fotografias e pictogramas).

Um fator que merece destaque refere-se à recuperação de memórias de experiências sensoriais, uma vez que esta desempenha um papel específico na percepção da mídia. Elleström explana que a leitura de um texto, por exemplo, envolve a criação e recordação não só de experiências visuais distantes da aparência das letras do alfabeto, mas também dos sons das palavras. Tal característica é

\footnotetext{
37 "The material modality can thus be defined as the latent corporeal interface of the medium."

38 "The sensorial modality is the physical and mental acts of perceiving the present interface of the medium through the sense faculties."
} 
essencial para a imagem de srsly Hamlet apresentada. É necessária a ativação da memória sensorial visual para que as páginas do livro sejam percebidas como um aplicativo de mensagens. Na passagem abaixo, além dos emojis e da menção no texto verbal, o uso de balões, a indicação de entrada (sinal de visto) e a marcação que novo texto está sendo digitado (três pontos) são exemplos da tentativa de despertar a memória visual do leitor a fim de reforçar a mídia imitada na obra.

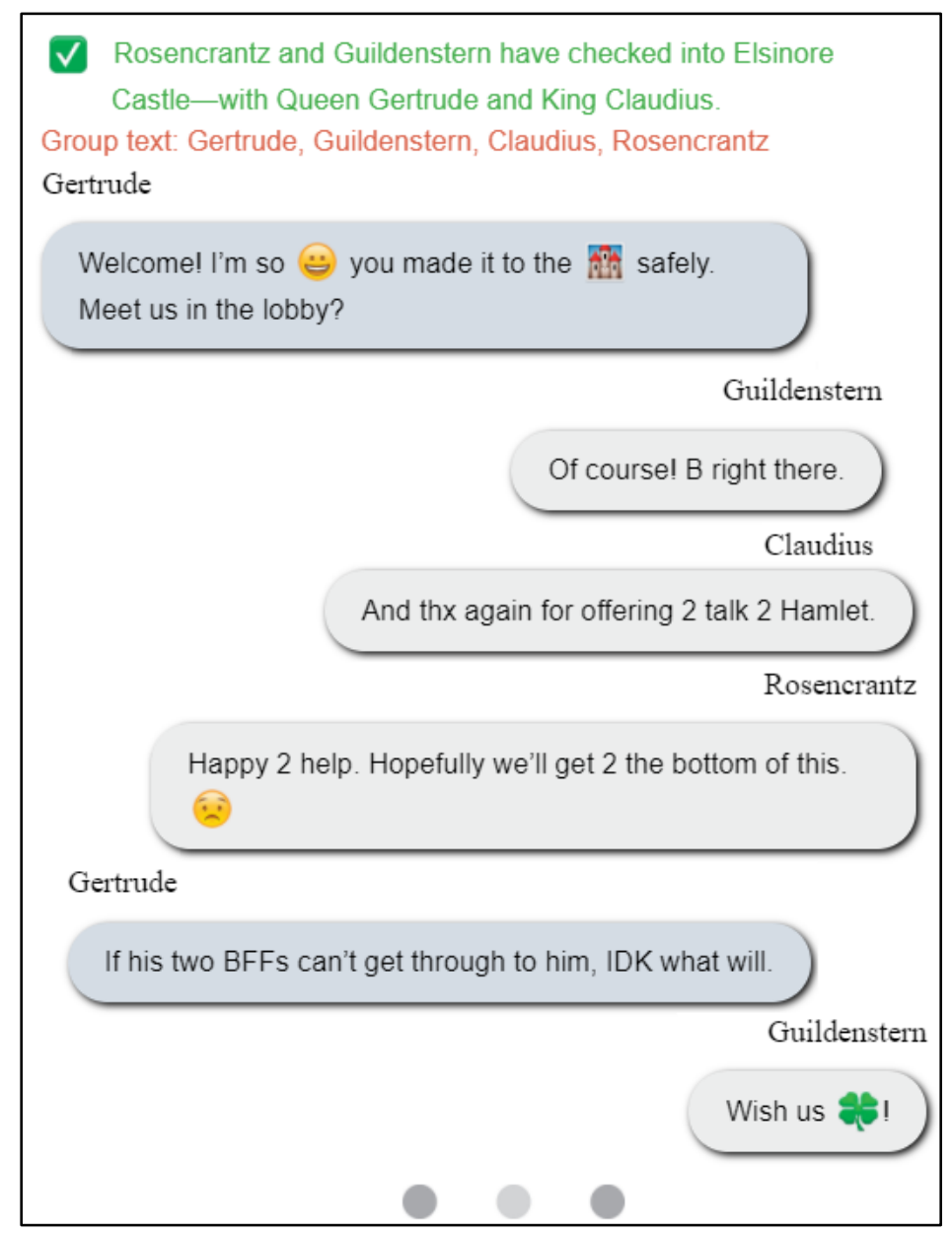

Figura 3 - Memória sensorial 39 Fonte: SHAKESPEARE; CARBONE, 2015, p. 32-33

Rosencrantz and Guildenstern chegaram ao Castelo Elsinore - com rainha Gertrudes e Rei Cláudio.

Mensagem de grupo: Gertrudes, Guildenstern, Cláudio, Rosencrantz

Gertrudes: Bem-vindos! Estou tão que vocês chegaram ao 网能 em segurança. Encontremnos no salão?

Guildenstern: Com ctz! Estaremos lá.

Cláudio: E obg novamente por se oferecerem $\mathrm{p} /$ falar c/ Hamlet.

Rosencrantz: Felizes em ajudar. Tomara que possamos descobrir a verdade sobre isso. Gertrudes: Se os seus dois BFFs não conseguirem falar c/ ele, não sei quem conseguirá.

Guildenstern: Deseje-nos 
A terceira modalidade, a espaçotemporal, "trata da estruturação da percepção sensorial dos dados da interface material das mídias em experiências e concepções de espaço e tempo" ${ }^{40}$ (ELLESTRÖM, 2010b, p. 18). A percepção espaçotemporal é constituída por quatro dimensões: largura, altura, profundidade e tempo. Uma escultura, por exemplo, apresenta as três dimensões espaciais físicas (altura, largura e profundidade). Uma vez que não tem a dimensão do tempo, a escultura é considerada estática (os dados sensoriais não se alteram). Deve-se destacar também a noção de espaço virtual, ou seja, mídias que não possuem as três dimensões espaciais em suas interfaces materiais, mas que apresentam um efeito tridimensional no momento da percepção e da interpretação. Assim, além do espaço como traço da interface midiática (a modalidade material considerada através da espaçotemporal), é possível se falar do espaço virtual (interpretação do que a mídia representa) e como aspecto cognitivo fundamental (os pensamentos têm padrões espaciais) (ELLESTRÖM, 2010b, p. 19-20). Portanto, pode-se dizer que as obras da série $O M G$ Shakespeare se caracterizam por uma interface bidimensional estática, uma percepção espacial atrelada a condições cognitivas e por um espaço virtual gerado no ato interpretativo. Essa espacialidade virtual é criada pela ilusão de profundidade percebida e interpretada pelo leitor. Esse efeito virtual pode estar vinculado à imitação de uma mídia digital, mas também pode ser visto como uma estratégia para a produção de certos itens de significação relacionados às peças de Shakespeare.

A presença da dimensão do tempo na modalidade espaçotemporal implica diferentes tipos de sequencialidade (fixa, parcialmente fixa e não fixa) nas mídias. Além disso, assim como na percepção espacial, é possível encontrar três níveis temporais nas mídias $\mathrm{O}$ mais fundamental dos níveis é o tempo como traço da interface da mídia (manifestação da modalidade material). Há também o tempo como condição necessária à percepção e cognição e a temporalidade virtual (interpretação do espaço em termos de passagem de tempo e o tempo da narrativa verbal). Elleström também destaca que todas as possibilidades espaciais e temporais relacionadas às interfaces e ilusões de tempo sequencial geram diferenças significativas entre as mídias (ELLESTRÖM, 2010b, p. 20-21).

\footnotetext{
40 "The spatiotemporal modality of media covers the structuring of the sensorial perception of sensedata of the material interface into experiences and conceptions of space and time."
} 
Na passagem abaixo, a menção ao Castelo Elsinore e a ilusão de profundidade produzida no formato dos balões de fala produzem um duplo espaço virtual (o grupo de mensagens e o salão do castelo). Com relação ao tempo, embora a obra não seja temporal (constituída de material estático) a ideia de sequencialidade é trazida pela narrativa verbal escrita (tempo virtual gerado pela troca de mensagens). A fotografia da taça com vinho, além de também trazer uma impressão de profundidade, produz uma ideia de movimento (a taça quebrando e o vinho se espalhando). Essa ilusão de movimento envolve a passagem de tempo. Trata-se, assim, de outro exemplo do que Elleström chama de tempo virtual.

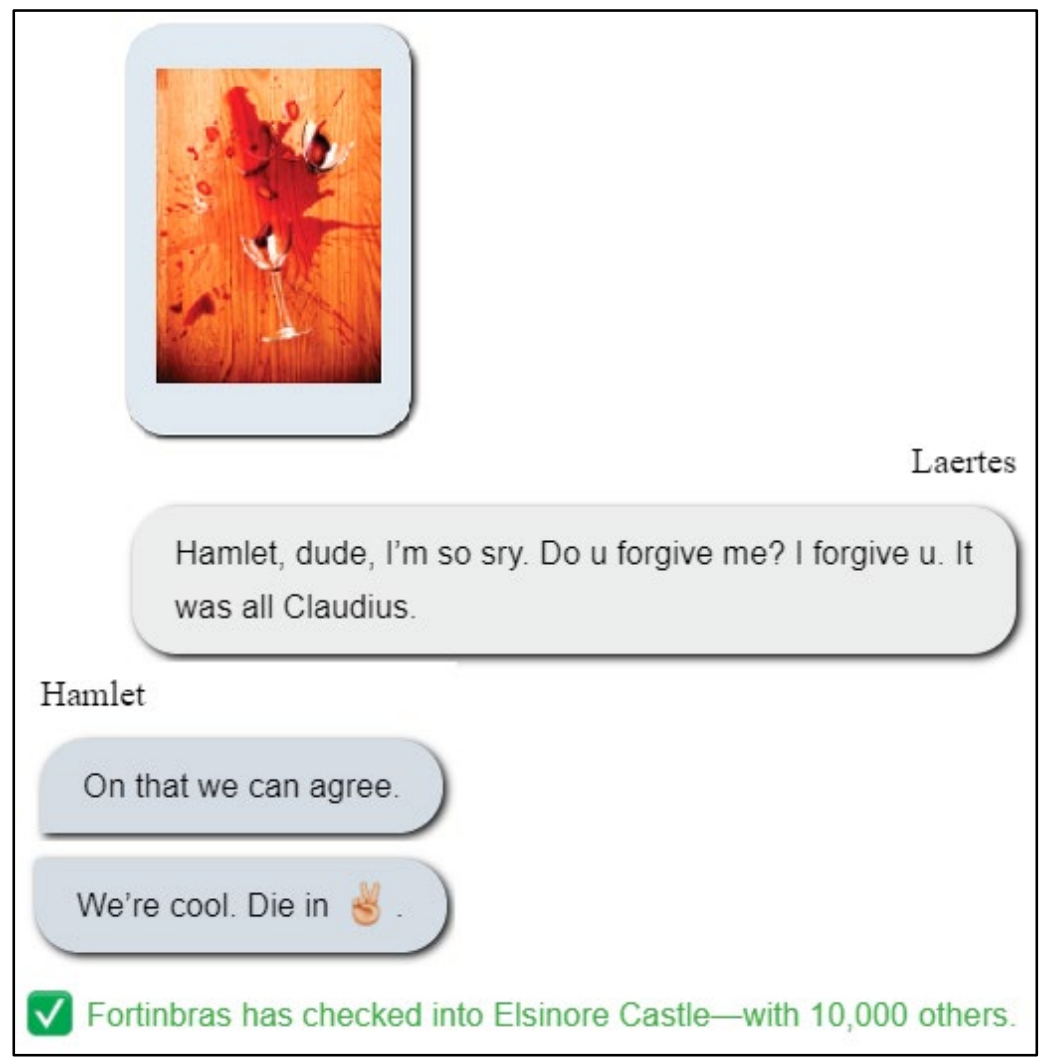

Figura 4 - Espaço e tempo virtuais ${ }^{41}$ Fonte: SHAKESPEARE; CARBONE, 2015, p. 99

A quarta modalidade é a semiótica e refere-se às características midiáticas relacionadas à representação. Essa modalidade é derivada das pré-semióticas e é a mais complexa delas. Pressupõe "a criação de sentido na mídia concebida em

\footnotetext{
${ }^{41}$ Laerte: Hamlet, cara, eu sinto mto. Vc me perdoa? Eu lhe perdoo. Foi tudo culpa de Cláudio. Hamlet: Nisso nós concordamos. Está tranquilo. Morra em 해.

च Fortimbrás entrou no Castelo Elsinore - com 10.000 outros.
} 
termos espaciais e temporais através de diferentes tipos de pensamento e de interpretação de signos" ${ }^{42}$ (ELLESTRÖM, 2010b, p. 22). Pode-se dizer, então, que todos os produtos midiáticos apresentam características semióticas, uma vez que, sem o reconhecimento dos signos, não há significação. Essas características semióticas possibilitam, mas também limitam, a transferência comunicativa entre mídias. Na proposta de Elleström, convenção, semelhança e contiguidade são os modos principais desta modalidade. Essa divisão está relacionada à tricotomia dos signos associados aos objetos proposta por Charles Peirce. O matemático estadunidense define o signo em uma relação triádica constituída por

uma coisa que serve para transmitir conhecimento sobre outra coisa, a qual acreditase que a signifique ou a represente. Essa coisa é chamada de objeto do signo; a ideia na mente que o signo desperta, que é um signo mental do mesmo objeto, é chamada de interpretante do signo. ${ }^{43}$ (PEIRCE, 1998, p. 13)

Assim, pode-se dizer que o objeto é o fenômeno físico ou cognitivo, o representamen é a representação desse objeto e o interpretante é a interpretação mental produzida a partir da relação entre os dois outros elementos. Apesar de reconhecer que não existem signos puros, Peirce divide-os de acordo com o modo de significação dominante. $\mathrm{O}$ índice pode ser considerado um signo reacional, já que "representa o objeto em virtude de uma conexão verdadeira com ele, ou porque obriga a mente a lidar com aquele objeto" ${ }^{44}$ (PEIRCE, 1998, p. 14). Tal signo vincula-se ao modo contiguidade apresentado por Elleström. Os ícones caracterizam-se pela semelhança com seus objetos. O símbolo, por outro lado, declara que determinado objeto é representado pelo signo associado a ele. É possível afirmar, portanto, que o símbolo é um "representamen que realiza sua função independentemente de qualquer semelhança ou analogia com seu objeto [...], mas só e simplesmente porque será interpretado como um representamen" ${ }^{45}$ (PEIRCE, 1998, p. 163). Deve-se deixar claro, no entanto, que esses tipos de signos

\footnotetext{
42 "The semiotic modality thus involves the creation of meaning in the spatiotemporally conceived medium by way of different sorts of thinking and sign interpretation."

43 "A sign is a thing which serves to convey knowledge of some other thing, which it is said to stand for or represent. This thing is called the object of the sign; the idea in the mind that the sign excites, which is a mental sign of the same object, is called an interpretant of the sign."

44 "An index stands for its object by virtue of a real connection with it, or because it forces the mind to attend to that object."

45 "A symbol is a representamen which fulfills its function regardless of any similarity or analogy with its object $[\ldots]$, but solely and simply because it will be interpreted to be a representamen."
} 
dificilmente são puros, isto é, eles tendem a atuar de forma cooperativa. O diagrama abaixo apresenta os principais modos de cada uma das categorias midiáticas propostas por Elleström. Essa categorização servirá de base para a análise das características multimodais e intermidiáticas presentes na obra srsly Hamlet.

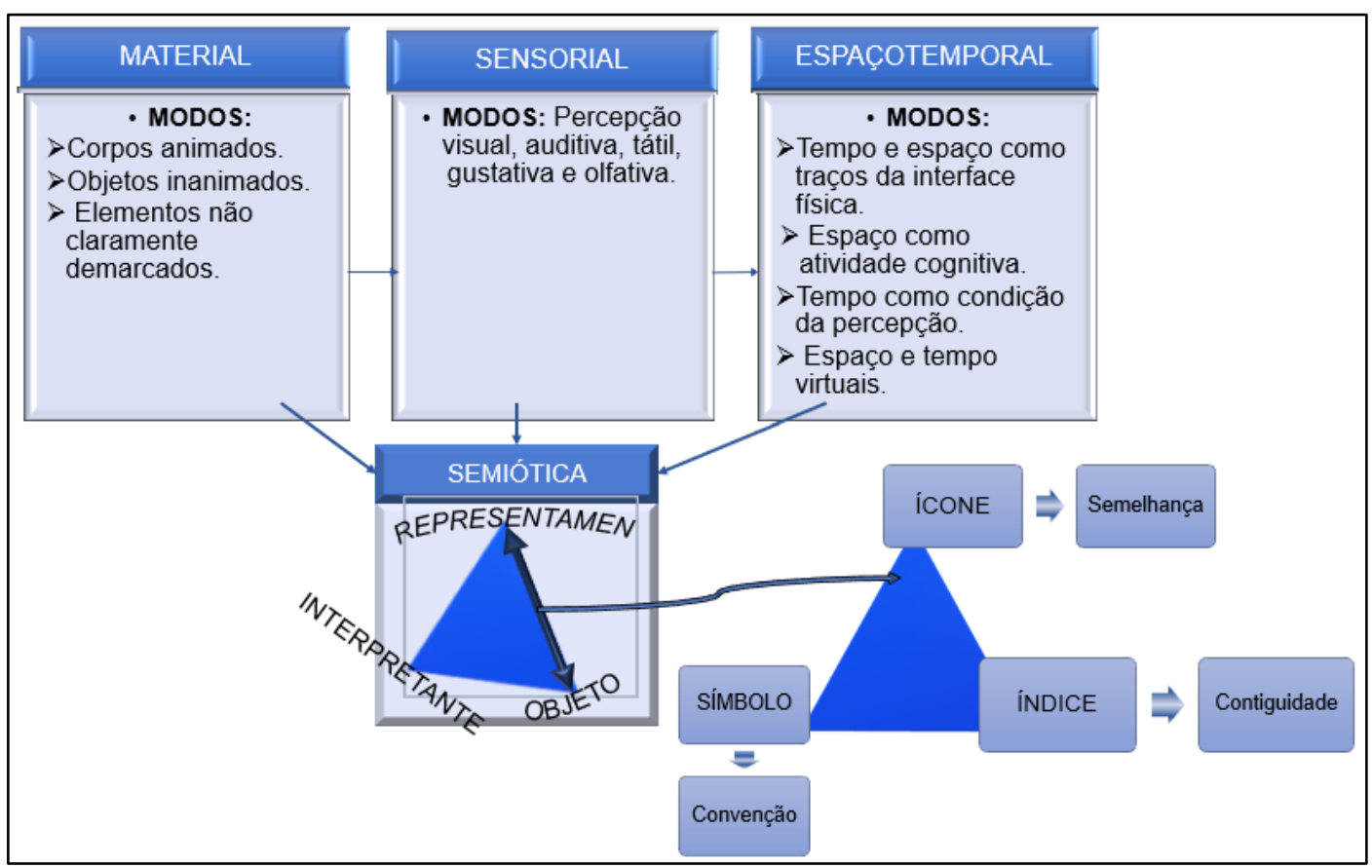

Diagrama 2 - As modalidades midiáticas

Fonte: Elaborado pela autora desta dissertação (2020)

Além das modalidades e modos, Elleström destaca dois aspectos qualificadores das mídias que complementam as modalidades e contribuem para a distinção entre as mídias. $\mathrm{O}$ aspecto qualificador contextual, como o próprio nome revela, está relacionado às convenções, práticas e aspectos sociais determinados historicamente e, por conta disso, apresenta propriedades diferenciadas. O segundo, o aspecto qualificador operacional, inclui características comunicativas e estéticas convencionalmente determinadas, ou seja, a mídia deve preencher certos critérios para ser aceita. As mídias que são geralmente identificadas por seu aspecto modal são chamadas mídias básicas. Por outro lado, as "[f]ormas de arte e outros tipos de mídia cultural sempre dependem muito dos dois aspectos qualificadores e, portanto, podem ser chamadas de mídias qualificadas" 46 (ELLESTRÖM, 2010b, p. 27).

46 "Art forms and other cultural media types always rely strongly on the two qualifying aspects and hence can be called qualified media." 
Deve-se deixar claro, no entanto, que as mídias qualificadas são mais fluidas, por possuírem critérios mais vagos, e necessitam se basear em uma ou mais mídias básicas. Além das mídias básicas e qualificadas, o teórico destaca a importância das mídias técnicas, ou seja, a forma que exibe ou concretiza as propriedades latentes dos outros dois tipos de mídias. Sem as mídias técnicas, as básicas e as qualificadas não passariam de abstrações, pois não teriam manifestações reais.

\subsection{1}

\section{Iconicidade e transmodalidade}

Segundo Elleström (2013c, p. 101), a iconicidade é um aspecto essencial na criação de sentidos em livros infantis. As estruturas icônicas produzem sentidos através das semelhanças que podem ser estabelecidas no cruzamento entre fronteiras sensoriais e espaçotemporais. Uma vez que srsly Hamlet caracteriza-se pelo uso não só de linguagem verbal, mas também de emojis, fotografias e desenhos lineares, torna-se importante discutir com mais profundidade a questão da iconicidade na produção de sentido e sua potencialidade multimodal.

No modelo semiótico de Charles Peirce, o ícone pertence à categoria da primeiridade, ou seja, relaciona-se com o objeto apenas através dos aspectos qualitativos. O matemático afirma, no entanto, que, na impossibilidade de existência de um ícone puro, o signo pode ser icônico independentemente de sua natureza, ou seja, ele pode apresentar características icônicas (algum grau de similaridade). Tais signos são chamados de hipoícones (PEIRCE, 1998, p. 273). Peirce os dividiu de acordo com o grau de iconicidade:

Aqueles que participam das qualidades simples, ou Primeira Primeiridade, são imagens; os que representam as relações, principalmente diádicas, ou assim são consideradas, das partes de uma coisa através de relações análogas em suas próprias partes, são diagramas; aqueles que representam o caráter representativo de um representamen através da representação de um paralelismo com outra coisa, são metáforas. ${ }^{47}$ (PEIRCE, 1998, p. 274)

\footnotetext{
47 "Those which partake the simple qualities, or First Firstnesses, are images; those which represent the relations, mainly dyadic, or so regarded, of the parts of one thing by analogous relations in their own parts, are diagrams; those which represent the representative character of a representamen by representing a parallelism in something else, are metaphors."
} 
Para Elleström, a distinção de Peirce apresenta algumas controvérsias na relação entre signo e objeto que podem dificultar a pesquisa sobre o assunto. Por esse motivo, adoto aqui a interpretação apresentada pelo professor sueco para solucionar tais dificuldades. Elleström considera uma escala de iconicidade relacionada a qualidades sensoriais e operações cognitivas, e os quatro estágios propostos são: imagem, diagrama forte, diagrama fraco e metáfora. As imagens podem ser consideradas substanciais e baseadas em semelhanças sensórias fortes. Elas demandam operações cognitivas simples, uma vez que não há grande distância/diferença entre as qualidades modais e o objeto. Os diagramas podem ser vistos como ícones relacionais, uma vez que se baseiam em relações diádicas. Por outro lado, as metáforas apresentam fraca iconicidade (maior distância entre objeto e signo) e, portanto, exigem operações cognitivas mais complexas para sua interpretação (ELLESTRÖM, 2013b, p. 104-107). Elleström acrescenta uma quarta divisão, ao dividir os diagramas em fortes e fracos. Os diagramas fortes refletem as relações internas do objeto de forma tangível e detalhada, ao passo que os fracos as refletem de maneira mais esquemática e abstrata (ELLESTRÖM, 2010a, p. 83).

Embora se reconheça que a iconicidade é um fenômeno conectado ao contexto e à percepção/interpretação, é interessante trazer alguns exemplos para a discussão sobre possíveis relações. Na passagem abaixo, é possível afirmar que os emojis, embora com fortes dimensões convencionais, apresentam diferentes camadas de iconicidade visual. O coração rosa com estrelas pode ser visto como um símbolo de amor/amar, mas também pode ser classificado como metáfora, uma vez que a semelhança é paralela/funcional. O fato de a descarga de adrenalina gerada por fortes emoções aumentar os batimentos cardíacos pode ser um dos elementos internos que conectam o objeto e o representamen. Além disso, a representação, além de se referir a um objeto cognitivo (sentimento), demanda grande generalização e não opera tendo por base a semelhança sensorial. Uma outra plausível metáfora presente na passagem é a do emoji "vara de pescar". Apesar de a iconicidade, em um primeiro momento, parecer forte, a interpretação latente (fisgar a verdade) só é possível dentro do contexto e a partir da transformação do interpretante (pescar) em um representamen cognitivo. Em ambos os exemplos, é a convenção que sustenta o aspecto icônico. 
Os demais emojis do fragmento podem ser considerados diagramas, ou seja, sua relação com o objeto é mais esquemática, relacional e estrutural. Os envelopes, apesar da presença dos símbolos (letra "E” e "coração"), apresentam forte iconicidade (a percepção sensorial é semelhante à que ocorre com os objetos que representam) e podem ser classificados como diagramas fortes. Por outro lado, é possível considerar o emoji "carinha piscando" um diagrama fraco. O aspecto sensorial não é tão imediato, ou seja, é necessário reconhecer que os traços e pontos em um círculo representam um rosto, e que o traço no lugar do ponto indica uma piscada. No caso do emoji do nariz, um outro exemplo de diagrama fraco, ocorre uma transmodalidade icônica sensorial; o representamen visual produz um interpretante (nose) que se torna o representamen auditivo para um objeto cognitivo (knows). Como se pode perceber, a iconicidade reside na estrutura sonora e é fraca.

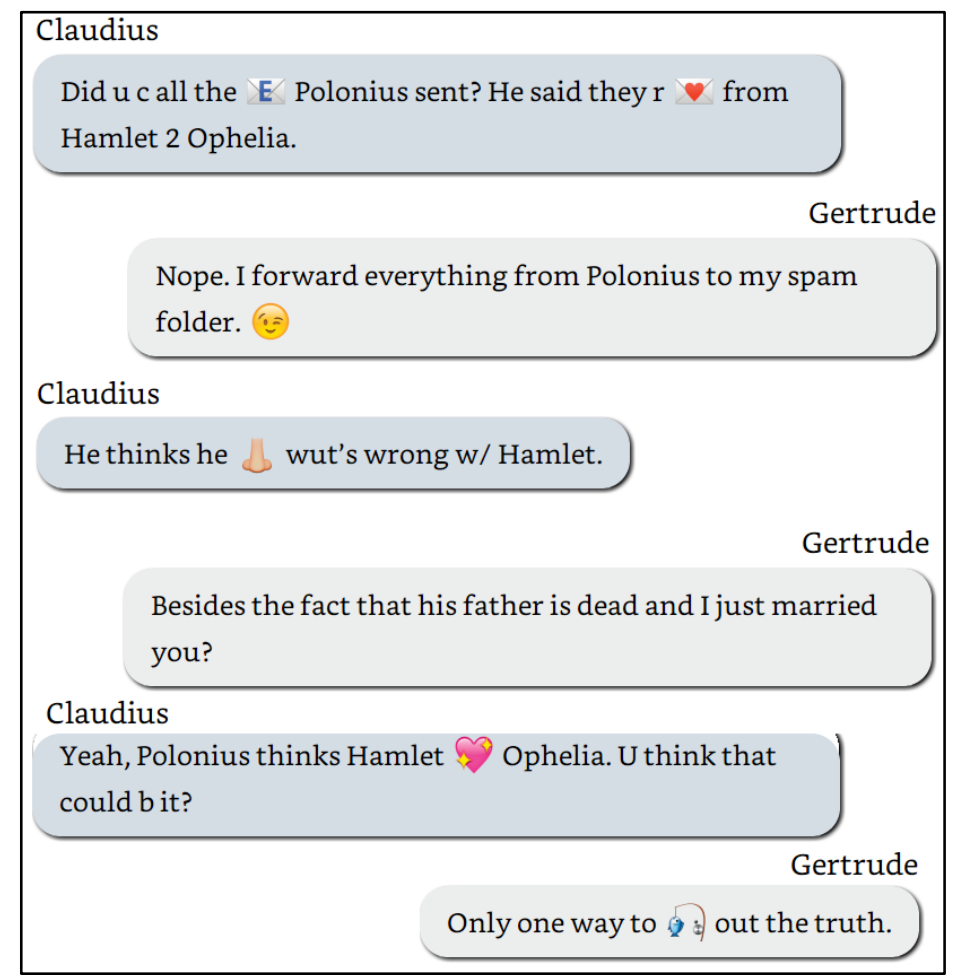

Figura 5 - A iconicidade nos emojis ${ }^{48}$

Fonte: SHAKESPEARE; CARBONE, 2015, p. 34

${ }^{48}$ Cláudio: Vc leu todos os $E$ que Polônio mandou? Ele disse que são ${ }^{-}$de Hamlet p/ Ofélia. Gertrudes: Não. Eu encaminho tudo que vem de Polônio para a minha pasta de spam.

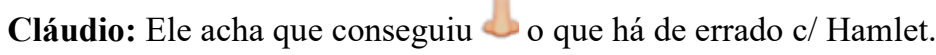

Gertrudes: Além do fato de que seu pai morreu e de que eu acabei de me casar c/ vc?

Cláudio: Sim. Polônio acredita que Hamlet Ofélia. Vc acha que pode ser isso?

Gertrudes: Só existe uma maneira de 2 a verdade. 
A iconicidade é um fenômeno cultural, multimodal e intermodal. Embora a iconicidade seja, em geral, monomodal, Elleström destaca que representamens visuais podem, por exemplo, representar objetos aurais ou cognitivos. $\mathrm{O}$ mesmo acontece em relação às modalidades material e espaçotemporal. Pode-se ter um representamen bidimensional representando um tridimensional. Isso ocorre "porque nossa mente, até certo ponto, tem a habilidade de perceber semelhanças entre áreas sensoriais e esferas mentais tanto idênticas quanto diferentes" 49 (ELLESTRÖM, 2018, p. 25).

Graças à capacidade intermodal, transformações midiáticas são possíveis. Além de os objetos representados poderem ser transmidiados em diferentes tipos de mídia, também é possível mídias representarem outras mídias (ELLESTRÖM, 2018, p.29). Pode-se afirmar que "um produto midiático específico pode retratar as mídias qualificadas como categorias abstratas e produtos midiáticos específicos" $" 50$ (ELLESTRÖM, 2013a, p. 120). Elleström divide essas representações em dois grupos. As citações, comentários, alusões ou menções são consideradas pelo teórico representações simples que podem ou não ter um papel importante na construção do sentido da obra. As representações complexas, por outro lado, são mais detalhadas e focadas em todos os tipos de características (dos traços formais e abstratos às características relacionadas ao conteúdo). Esse segundo tipo geralmente representa produtos de mídia específicos (Ibid., p. 120-122). A divisão proposta por Elleström pode ser relacionada, como o próprio teórico destaca, ao conceito de referência intermidiática (explícita e implícita) de Irina O. Rajewsky discutido no início desta seção.

O debate a respeito dos tipos de referências nas relações intermidiais é importante para esta dissertação porque a análise enfoca uma obra adaptada que procura reproduzir a estrutura formal de uma mídia técnica distinta daquela que lhe dá suporte. Pode-se considerar também que srsly Hamlet e as demais obras da série, consideradas como representamens das peças shakespearianas e da mídia digital, são exemplos de transmodalidade icônica, ou seja, a representação baseada em

\footnotetext{
49 "This is because our mind, to a certain extent, has the ability to perceive resemblances not only within the same but also across different sensory areas and different mental realms."

50 " [...] specific media product can represent both qualified media as abstract categories and particular media products."
} 
semelhanças cruza fronteiras entre as modalidades (material, sensorial, espaçotemporal).

\section{6}

\section{Caracterização da literatura infantil e juvenil}

Em primeiro lugar, faz-se necessário justificar a escolha da nomenclatura empregada no título desta seção e ao longo da dissertação. A opção pelo uso do conectivo "e" na denominação, em lugar do composto "infanto-juvenil", busca reforçar a natureza híbrida e agregadora dessa literatura. Como parte de um sistema dinâmico, essa literatura não é homogênea e se desenvolve na experimentação e na interação de elementos, muitas vezes, contraditórios. Tal capacidade de abarcar diferentes modalidades e dimensões permite interfaces profícuas com a perspectiva descritivista, sistêmica e cultural presente nos Estudos de Tradução e de Adaptação. Contudo, o sistema literário infantil ocupou durante muito tempo uma posição marginal tanto no polissistema literário quanto nos estudos acadêmicos.

Em relação à academia, uma das possíveis causas para a desvalorização do sistema literário infantil e juvenil pode estar associada ao fato de que, dentro de uma visão histórico-cultural do conceito de infância, a literatura voltada para crianças e jovens era vista como um veículo pedagógico e utilitário e, portanto, ocupando uma posição inferior ao da literatura voltada para adultos. A própria baixa posição social que as crianças parecem ainda ocupar pode também contribuir para o pouco reconhecimento dessa categoria literária. Os autores de obras literárias voltadas para o público não adulto, em muitos casos, ainda não são reconhecidos pelo sistema literário e, várias vezes, eles mesmos consideram suas obras secundárias ou inferiores. Essa ausência de legitimação em termos literários fez com que a literatura infantil e juvenil não fosse, durante muito tempo, considerada adequada para os estudos acadêmicos

Ao contrário de outras categorias do sistema literário, a conceituação de infância e de livros produzidos especificamente para crianças são ocorrências recentes. Pode-se afirmar também que, desde o início de sua formação, o sistema literário infantil e juvenil dependia da ideologia do sistema educacional para sua legitimação e desenvolvimento. Em sua obra Poetics of Children's Literature (1986), a autora israelense Zohar Shavit, ao discutir a formação da literatura infantil 
no ocidente, destaca que até o século XVII poucas obras literárias especificamente voltadas para o público infantil foram publicadas. Segundo ela, as crianças que sabiam ler (geralmente pertencentes às classes privilegiadas) só tinham acesso às mesmas obras lidas pelos adultos ou liam livros de alfabetização ou de etiqueta. Essas obras mais específicas visavam, em princípio, ensinar o comportamento adequado para crianças de elevada posição social. Somente a partir do final do século XVII é que se passou a considerar as crianças como seres que deveriam ser protegidos e aprimorados (bem-estar social e psicológico) através da educação. Originou-se, então, uma demanda na produção de livros especificamente criados para elas. Os primeiros livros oficiais ligavam-se ao ensino religioso. Aos poucos, as necessidades do público leitor infantil passaram a ser geradas por um novo sistema educacional fundamentado nas escolas. A escola moralista (baseada nas concepções de Locke ou Rousseau) não via a criança como pecadora, mas como inocente, alguém que precisava ser formado. Com a utilização de novos gêneros de livros, o sistema literário infantil ampliou-se e se tornou heterogêneo.

Um outro fator essencial para a formação do sistema literário infantil e juvenil foi a competição com modelos do sistema literário inicialmente voltado para adultos. No século XVIII, os chapbooks (tipo de folhetos baratos) eram muito populares, principalmente entre as classes menos privilegiadas, e acabaram por se tornar o material de leitura dominante entre as crianças de todas as classes sociais. As casas editoriais, reconhecendo o potencial do novo mercado, passaram a publicar livros que atraíssem jovens leitores sem violar as expectativas de educadores e pais. Como exemplo dessa visão comercial, é possível citar John Newbery (1713-1767). Ele foi um dos primeiros editores a publicar e ter sucesso com obras infantis e juvenis e se destacou por ter usado ilustrações nas publicações como uma das estratégias para agradar crianças e adolescentes e competir com os chapbooks (SHAVIT, 1995, p. 30-34). Assim como os editores de livros, as escolas religiosas e as moralistas buscaram oferecer substitutos para os chapbooks, pois os consideravam inadequados. Houve uma tentativa de tornar os livros mais atraentes, empregando, inclusive, características dos livros que eram combatidos (histórias, ilustrações etc.). Por conta da oposição gerada, os produtores dos chapbooks também buscaram uma melhoria na qualidade do produto e passaram a ter publicações específicas para os jovens leitores. O papel das escolas na produção de 
livros, o aumento no número de leitores e o combate ao chapbooks formaram as estruturas dos subsistemas canonizados e não canonizados. No século XIX, com o surgimento da divisão por faixa etária, novos subsistemas surgiram.

O papel dos chapbooks merece também destaque porque eles garantiam a presença da imaginação e da tradição oral no material oferecido aos jovens leitores. Mesmo com uma maior heterogeneidade do sistema literário infantil e juvenil, as literaturas religiosa, moralista e comercial consideravam a ficção, principalmente os contos de fada, nociva aos jovens. Esses contos só eram publicados nos chapbooks, o que acabava por reforçar a visão negativa que se tinha dessa espécie de publicação. Somente na segunda metade do século XIX esse tipo de narrativa passou a fazer parte da literatura considerada oficial (SHAVIT, 1986).

A necessidade de criação de livros direcionados para o leitor jovem encontrase associada a alterações na percepção social que se tinha das crianças. O historiador Philippe Ariès traça uma perspectiva europeia da infância do século XII ao XX na obra História Social da Criança e da Família (1986). De acordo com o autor, durante o período medieval a infância ocupava uma posição invisível na sociedade. Nessa época, a criança era vista como membro da sociedade adulta. O sentimento da infância, ou seja, a consciência da particularidade infantil, passou a ser considerado somente a partir do final do século XVI e início do século XVII. Desse período em diante, as crianças, principalmente os meninos das classes sociais mais abastadas, deixaram de ser vistas como adultos em miniatura para se tornarem uma entidade separada em todas as atividades sociais. A criança também passa a ser relacionada a ideias de fragilidade, inocência e diversão. Esse novo ponto de vista acabou levando à visão da criança como fonte de entretenimento e relaxamento para os adultos. Em oposição a esse tratamento das crianças, começou a surgir uma preocupação moral e educacional para com elas. Aos poucos, houve um prolongamento da infância para além dos primeiros anos e uma busca pela compreensão da mente da criança a fim de aprimorar os métodos de educação. Shavit (1983, p. 60) destaca que o principal veículo pedagógico da época eram os livros. A pesquisadora também aponta para o fato de que os escritores de livros voltados para crianças e jovens tinham restrições não só impostas pelo sistema literário, mas também pelo sistema educacional, que, baseado na concepção de criança da época, determinava o que as crianças podiam e deviam ler. 
Como já visto, a partir da metade do século XVII, como ocorreu com o vestuário, as atividades de lazer e o trabalho, houve uma divisão na produção literária para o público adulto e para o jovem. Essa polarização literária gerava não só uma dualidade de leitores, mas também de tipos de obra destinados a cada um deles. Ariès, ao falar sobre as mudanças em relação às características e público dos contos de fadas na França, destaca que

[...] na segunda metade do século, começou-se a achar esses contos muito simples. Ao mesmo tempo, surgiu por eles um novo tipo de interesse, que tendia a transformar num gênero literário da moda as recitações orais tradicionais e ingênuas. Esse interesse manifestou-se de duas maneiras: nas publicações reservadas às crianças, ao menos em princípio, com os contos de Perrault, que ainda revelavam uma certa vergonha em admitir o gosto pelos velhos contos, e nas publicações mais sérias, destinadas aos adultos, e das quais se excluíam as crianças e o povo. (ARIÈS, 1986, p. 120)

Nota-se, na passagem acima, uma natureza avaliativa na distinção entre os dois tipos de categorias (infantil e para adultos de classes privilegiadas). Tal divisão pode ser vista como um prenúncio da oposição entre o sistema literário infantil canonizado (intelectualizado e dirigido para adultos) e o não canonizado (popular e voltado para crianças e jovens). O caráter dual das obras voltadas para o público infantil envolve a necessidade de atender adultos e crianças e de cumprir as expectativas, algumas vezes contraditórias, da sociedade em relação às obras voltadas para o público infantil e juvenil. Shavit (1986, p. 71-91) cita como exemplo dessa dualidade e ambivalência (presença no sistema literário infantil e juvenil e no adulto) o clássico infantil intitulado Alice no País das Maravilhas (1865) de Charles Lutwidge Dodgson (Lewis Carroll). O autor escreveu três versões da obra com status diferente. A primeira (publicada em 1885) e, principalmente, o sucesso comercial de 1865 apresentam estruturas e elementos narrativos sofisticados (paródia de modelos estabelecidos, a relação porosa entre realidade e fantasia e junção de três diferentes modelos literários) que possibilitam a ambivalência. A terceira versão (A Cuidadosa Alice), publicada em 1890 e voltada apenas para o sistema infantil, reflete os mesmos procedimentos empregados na época nas adaptações voltadas para crianças (por exemplo, tom didático, simplificação na manipulação das relações entre tempo e espaço e entre fantasia e realidade e ausência da paródia e da sátira). 
Como já discutido acima, as obras literárias infantis caracterizam-se, em oposição ao sistema literário adulto, pela divisão entre o pedagógico e o lúdico. Há também o envolvimento de dois grupos de leitores implícitos nessa categoria. $\mathrm{O}$ critério de aceitação de uma obra no sistema literário infantil oficial e canônico envolve ser coerente com as ideologias pedagógicas do período e ser capaz de atrair os adultos, responsáveis pela crítica e pela escolha das obras (elementos da patronagem) (SHAVIT, 1986).

A partir da perspectiva que surgiu no século XVII, acreditava-se que as obras voltadas para o público infantil e juvenil deveriam ser condizentes com suas capacidades e necessidades. "É claro que a compreensão dessas necessidades e capacidades não era fixa, mas mudava de período a período, consequentemente mudando o caráter dos textos para as crianças também" ${ }^{51}$ (SHAVIT, 1986, p. 7). Shavit também destaca que o reconhecimento da criança como leitor de uma obra e o baixo status que o sistema literário infantil parece ainda ocupar no polissistema gera coerções que não estão relacionadas a questões comerciais ou à poética de polissistemas literários, mas à visão de que obras infantis devem não apenas ser produzidas sob a supervisão de adultos, mas também ser adequadas em termos pedagógicos e contribuir para o desenvolvimento da criança. Tomando como exemplo o sistema literário infantil hebraico, Shavit destaca como coerções que controlam o sistema a necessidade de se dirigir a crianças e adultos (adequar-se às demandas dos dois sistemas) e a tendência desse sistema à autoperpetuação, ao conservadorismo (aceitação de novas normas somente se já tiverem sido legitimadas em outros sistemas), à valorização dos modelos já conhecidos e à relutância em aceitar novos modelos (SHAVIT, 1986, p. 63).

Uma outra questão discutida por Shavit e que merece ser abordada é a de normas predominantes na reescrita para o sistema literário infantil e juvenil. A estudiosa israelense apresenta o conceito semiótico de tradução cultural, isto é, não só textos, mas modelos textuais e culturais são transferidos para o sistema-alvo (SHAVIT, 2016, p. 120). Ao discutir tradução e outras formas de reescrita para o sistema literário infantil hebraico, Shavit (1986, p. 112-113) destaca que há uma maior liberdade em relação ao texto por conta da posição periférica que o sistema-

51 "Of course, the understanding of these needs and capacities was not fixed, but changed from period to period, consequently changing the character of the texts for children as well." 
alvo parece ocupar. Essa maior possibilidade de manipulação do texto pode também estar relacionada à concepção de que leitores muito jovens têm dificuldade em ler textos extensos demais. Além da redução do texto, há uma preocupação com a simplificação. Shavit conclui que, além das escolhas motivadas por temas e autores (canonizados), os procedimentos de tradução para a entrada no sistema literário infantil seguem dois princípios básicos: o texto deve ser, de acordo com as expectativas da sociedade, útil e adequado para os leitores jovens (questões morais e educacionais) e, principalmente, os ajustes da narrativa e linguísticos precisam ser compatíveis com as capacidades de compreensão desses leitores. Observa-se, portanto, pouca distinção entre as normas que regem a produção de textos considerados originais e de reescritas no sistema literário infantil e juvenil.

Srsly Hamlet pode ser visto como uma transposição de um texto do subsistema literário canônico adulto para um subsistema literário periférico infantil. Essa adaptação parece seguir os dois preceitos para a entrada no sistema literário voltado para não adultos. As simplificações e outros alinhamentos em termos linguísticos e de elementos da narrativa serão discutidos nos próximos capítulos. Destaca-se, neste momento, o reconhecimento dos dois leitores implícitos da obra por parte da Penguin Random House Company (PRH). No verso da folha de rosto da adaptação, a editora indica um site para jovens (com artigos, promoção de outras obras e quizzes relacionados aos temas dos livros divulgados) e um para educadores e bibliotecários com sugestões de "ferramentas pedagógicas". No site voltado para os adultos, além da divulgação de obras e o acesso a guias e atividades vinculados a elas, há vídeos sobre processos de montagem e a possibilidade de se convidar autores para debates nas escolas. Na página destinada à divulgação internacional das obras da editora, há uma recomendação de faixa etária (14 anos ou mais), o que insere srsly Hamlet em um determinado subsistema, e há referências a ferramentas educacionais que associam o texto às habilidades de leitura exigidas dos leitores. De acordo com a escala Lexile, comumente empregada nas escolas americanas, o livro é $N P$, isto é, ele não recebeu uma medição porque não foi considerado prosa. O outro sistema de avaliação de leitura mencionado, Fountas \& Pinnell, indica o livro para alunos do ensino médio e para adultos $\left(\mathrm{Z}^{+}\right)$. Observa-se, portanto, que nos dois sites voltados para os leitores adultos, além da questão comercial, há uma forte ligação da obra com o aspecto educacional. 
Com relação a Courtney Carbone, o único momento em que ela parece reconhecer as expectativas do leitor adulto é quando, no verso da folha de rosto, ela pede desculpas aos professores de língua inglesa. Tal fato pode ser uma forma de indicar que a obra não atende às diretrizes pedagógicas esperadas.

\subsection{1}

\section{A literatura infantil e juvenil nos Estados Unidos}

Uma vez que a adaptação analisada nesta dissertação foi publicada nos Estados Unidos e tem como público-alvo a sociedade estadunidense, é importante delinear alguns aspectos básicos do sistema literário infantil e juvenil desse polissistema. Assim como na Europa, os primeiros livros voltados para crianças nos Estados Unidos tinham uma preocupação com a transmissão de bons costumes. Os professores de literatura infantil Michael O. Tunnel e James S. Jacobs (2013, p. 80) salientam que na América colonial, principalmente entre os puritanos, as crianças eram vistas como más, e o material de leitura existente estava voltado para sua salvação. Esse aspecto moralizante e didático foi dominante nas obras para jovens até o século XX. O século XIX trouxe várias revistas voltadas para o público jovem e, com muitas delas, desenvolve-se o conceito da leitura por prazer. Ao falar sobre a publicação de livros infantis nos Estados Unidos, Connie C. Epstein (2005) destaca que, na segunda metade do século XIX, houve a publicação de inúmeras obras que se tornaram clássicos da literatura infantil e o surgimento, com a obra Mulherzinhas de Louisa May Alcott, da tradição americana de histórias familiares realistas. Contudo, as editoras americanas ainda dependiam dos títulos britânicos conhecidos. No início do século XX, as ilustrações começam a ser usadas como parte da construção dos sentidos das obras, não apenas como decorações (TUNNELL; JACOBS, 2013). Epstein (2005) aponta que, a partir da segunda década do século $\mathrm{XX}$, as editoras começaram a prestar mais atenção nas publicações para jovens, destinando funcionários e/ou departamentos específicos. Além do aumento de vendas, um dos fatores que contribuiu para essa especialização nas editoras foi a separação das áreas de leitura para crianças nas livrarias públicas, o que gerou maior necessidade de livros. Na década de 1950, a publicação de livros infantis e juvenis tornou-se um negócio lucrativo e competitivo. Em 1965, a "Lei de Educação Elementar e Secundária" (ESEA em inglês) forneceu dinheiro para 
que as bibliotecas escolares comprassem livros, e as vendas cresceram de maneira vertiginosa. Livros começam a lidar com questões tidas como tabus para essa categoria literária. Com a Guerra do Vietnã, na década de 1970, e uma postura mais isolacionista da sociedade estadunidense, houve uma queda nas vendas de obras traduzidas onde $o$ aspecto cultural fosse marcado. Epstein (2005, p. 475) destaca a impressão de que os americanos estavam mais interessados em "apagar as diferenças culturais encontradas dentro do país do que em aprender sobre elas" 52 . A queda nos orçamentos fez com que os bibliotecários perdessem a posição de destaque na escolha de livros. Com o avanço das livrarias, os padrões para compras sofreram alterações, ou seja, houve uma maior procura por livros ilustrados e voltados para jovens leitores. Com a expansão e consolidação do mercado, as editoras se aperfeiçoaram. A Random House foi, em 1983, a primeira empresa a estabelecer um departamento de vendas especializado em livros infantis e juvenis (EPSTEIN, 2005, p. 476). A partir da metade da década de 1980, o consumo de livros nas escolas voltou a crescer. Tunnell e Jacobs (2013, p. 85) também ressaltam que, no século XXI, novos prêmios dentro da categoria de literatura infantil e juvenil surgem, e a literatura fantástica e as graphic novels ampliam a popularidade que tinha começado no século anterior. A possibilidade de transgressão em termos de poética é mantida, isto é, "autores e ilustradores de livros infantis continuam a fazer experiências com formas e conteúdo" ${ }^{, 53}$, e temas considerados polêmicos se tornam mais comuns na literatura voltada para jovens adultos.

\section{7 \\ 0 teatro elisabetano}

Uma das mídias que srsly Hamlet evoca é o teatro, destacadamente o elisabetano. Tendo-se consciência que a escolha de uma determinada mídia afeta o sentido da obra, é necessário, então, discutir alguns dos elementos que caracterizam esse meio na época de Shakespeare. Embora o teatro elisabetano refira-se, em princípio, ao período histórico associado ao reinado da Rainha Elizabete (15581603), esta dissertação usa esse termo para se referir a uma série de características

\footnotetext{
52 "Apparently these editors concluded Americans were now more interested in erasing the cultural differences found within the country than in learning about them."

53 "Authors and illustrators of children's books continue to experiment with form and content."
} 
e convenções encontradas no teatro inglês até 1642, quando os teatros públicos foram fechados.

Segundo o estudioso Michael Hattaway (1982, p. 9), o primeiro prédio construído na Inglaterra, desde a época romana, para a apresentação de peças foi o Theatre do ator James Burbage em 1576. Com sua inauguração, iniciou-se o estabelecimento de grandes companhias teatrais, uma maior concentração de recursos (humanos e financeiros) e um aumento na quantidade e qualidade das produções, a fim de atrair um público mais numeroso e heterogêneo. Observa-se, no entanto, que apesar das mudanças, houve uma continuação em termos de tradições teatrais, ou seja, manteve-se a junção entre o drama medieval e o renascentista (HAPPÉ, 2004, p. 27). Alguns costumes relacionados a outras formas de diversão da época (bear-baiting, apresentações de esgrima ou tiro com arco, espetáculos de magia, de música ou de dança e os bobos/palhaços das casas dos nobres), por exemplo, aparecem, de uma forma ou outra, nas obras dos dramaturgos da época (Ibid., p. 36).

Hattaway também destaca que o "palco, para os elisabetanos, não era um lugar remoto e dissociado, mas um espaço no qual homens de seu próprio tempo e de sua comunidade podiam atuar" 54 (1982, p. 23-24). Uma outra característica do teatro da época é que o mundo imaginário da peça e o mundo material da atuação constituem diferentes registros de percepção, diversão e engajamento (WEIMANN, 2000, p. 10), ou seja, o público tinha consciência da existência dessas dois espaços (representação e apresentação / história e palco) que se entrelaçam na construção da peça. Havia também uma valorização da cultura auditiva e da retórica (os sermões eram comuns na sociedade londrina).

A respeito dos signos teatrais, é importante destacar que quase não havia cenário, e os poucos recursos visuais eram, em geral, portáteis (coroas, espadas, velas etc.). Pode-se dizer, portanto, que, o cenário predominante na época é o verbal. Em Shakespeare, por exemplo, "passa-se sem dificuldade de um local exterior para outro interior, [...]. As cenas encadeiam-se sem que seja necessário oferecer algo além de uma simples indicação espacial [menção] ou uma troca de palavras [...]" (PAVIS, 2008, p. 44). Por outro lado, o vestuário era mais exuberante

\footnotetext{
54 "The stage was, for the Elizabethans, not a remote other place but a space on which men of their own time and of their own community might play, [...]."
} 
e constituía "na verdade, uma linguagem, um sistema de signos, cujos sentidos derivavam de seus próprios códigos e não de uma congruência com a realidade" 55 . Assim, reis portavam coroas, virgens vestiam-se de branco e servos usavam casacos azuis (HATTAWAY, 1982, p. 86-87).

Embora generalizações não possam ser feitas, outras convenções comuns no jogo dramático que merecem destaque são: 1) o uso de solilóquios e apartes (discurso do personagem dirigido a si próprio e/ou ao público); 2) o esquema prosódico do verso (blank verse); 3) a presença do coro; 4) a utilização do recurso do teatro dentro do teatro (PAVIS, 2008, p. 71, 385-386); e 5) o emprego de pantomimas e de cenas onde ocorrem escutas secretas.

Ao trazer para a sua obra alguns dos elementos e convenções do teatro elisabetano sob nova roupagem, Carbone estabelece um novo contrato com seu leitor, ampliando a consciência a respeito da natureza simbólica da peça shakespeariana.

\footnotetext{
55 "Costume in fact was a language, a system of signs, whose meanings derived from its own codes
} and not from congruence with reality." 


\section{O Bardo no polissistema literário estadunidense

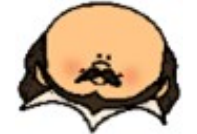

A fim de analisar as estratégias empregadas na obra srsly Hamlet, é necessário apresentar alguns elementos que podem ter contribuído para a sua criação em 2015.

\section{1}

\section{A patronagem}

O fato de a obra de Carbone ter sido publicada pela Random House Children's Books, uma divisão da Penguin Random House Company (PRH) merece destaque. De acordo com a professora Valerie Peterson (2019), trata-se de uma das cinco maiores editoras nos Estados Unidos e ter seus livros publicados por ela implica ter vários benefícios, além do status obtido. Peterson (2018) aponta como vantagens a possibilidade de se ter uma equipe de editores, designers e outros funcionários para garantir que o produto final tenha uma alta qualidade, a variedade de canais de vendas e o apoio de um departamento de propaganda. A obra, por exemplo, tem uma página no site de vendas internacionais da editora (PENGUIN RANDOM HOUSE INTERNATIONAL SALES, 2015?). As vendas são feitas para mais de 240 países e há representantes em vários deles. O poder da casa editorial, dentro da noção de patronagem de Lefevere, valoriza a obra. Esse prestígio é ainda mais reforçado pelo fato de que a PRH foi a casa editorial que teve, nos anos de 2014 e 2015, mais obras infantis que se tornaram sucessos de vendas (MILLIOT, 2016a).

A própria PRH destaca sua importância ao se identificar em uma página de seu site como a maior editora de livros do mundo (THE AUTHOR NEWSLETTER TEAM \& THE PENGUIN RANDOM HOUSE LEGAL DEPARTMENT, 2018). Além disso, ao colocar no verso da folha de rosto de srsly Hamlet o fato de apoiar a Primeira Emenda da Constituição dos Estados Unidos (1791), ela pode estar se valendo de uma estratégia para destacar seu poder de proteção em relação aos autores e editores. Em seu site, a editora não só destaca a experiência de sua equipe legal para garantir a liberdade de expressão de seus autores, mas também o seu papel como apoiadora de instituições que lutam por essa liberdade e pelo direito à 
leitura. Pode-se dizer, assim, que publicar por essa editora garante maior qualidade e visibilidade da obra, podendo gerar maiores lucros, e maior proteção em termos jurídicos.

\section{2}

\section{Vendas de livros}

Em relação ao componente econômico, como a tabela abaixo revela, no ano (2015) em que os livros para colorir dominaram as vendas nos Estados Unidos (categoria de Arte/Arquitetura/Design/Fotografia), o mercado de obras clássicas para adultos e jovens continuou em crescimento. Tal fato destaca-se ainda mais ao se detectar que houve queda em várias categorias de obras voltadas para o público jovem.

\begin{tabular}{|c|c|c|c|}
\hline \multicolumn{4}{|c|}{ Unit Sales by Category, 2014-2015 (in thousands) } \\
\hline & 2014 & 2015 & \% Change \\
\hline \multicolumn{4}{|l|}{ Adult Non-Fiction } \\
\hline Art/Architecture/Design/Photography & 6,984 & 11,172 & $60 \%$ \\
\hline Biography/Autobiography/Memoir & 22,803 & 23,544 & $3 \%$ \\
\hline BusinessiEconomics & 16,604 & 17,155 & $3 \%$ \\
\hline \multicolumn{4}{|l|}{ Adult Fletion } \\
\hline Classtes & 7,578 & 9,985 & $32 \%$ \\
\hline Occult:PsychologicaliHomor & 3,329 & 2,218 & $-33 \%$ \\
\hline Religion & 4,174 & 4,414 & $6 \%$ \\
\hline \multicolumn{4}{|l|}{ Juvenile Non-Fiction } \\
\hline Animals & 4,625 & 5,128 & $11 \%$ \\
\hline Biographies/Autobiographies & 3,979 & 4,253 & $7 \%$ \\
\hline Concepts & 3,790 & 4,296 & $13 \%$ \\
\hline Education/ReferencelLanguage & 6,496 & 7,651 & $18 \%$ \\
\hline \multicolumn{4}{|l|}{ Jumenile Fiction } \\
\hline Aximats & 9,051 & 10,112 & $12 \%$ \\
\hline Classics & 9,981 & 10,161 & $2 \%$ \\
\hline Concepts & 8,909 & 9,307 & $4 \%$ \\
\hline Science Fiction/Fantasy/Magic & 45,511 & 44,578 & $-2 \%$ \\
\hline
\end{tabular}

Tabela 1 -Venda de livros nos Estados Unidos por categoria Fonte: MILLIOT, 2016b 
A Companhia de Análise de Dados Nielsen também destaca que, em 2015, as três categorias de livros de ficção mais vendidos foram ficção científica (44\%), clássicos (32\%) e graphic novels (22\%). Merece também ser destacada a questão de que, apesar de uma redução na venda de e-books em comparação com 2014 (de $27 \%$ para $24 \%$ ), houve um aumento significativo na venda para leitura em smartphones (de 7.6\% para 14.3\%) (NIELSEN, 2016). Tal fato pode indicar uma valorização dos aparelhos celulares como mídia técnica para a leitura. Assim, a escolha do formato na adaptação de Carbone pode estar relacionada a essa tendência.

A discussão sobre o índice de vendas é importante por ser um elemento que interfere na escolha de novas obras para publicação. Mesmo com um crescimento menor em relação a outras categorias, o número de clássicos vendidos supera itens com crescimento maior. Assim, o estímulo à publicação nessa categoria parece ser natural.

Cabe também ressaltar que na época de William Shakespeare não havia direitos autorais garantidos. Como salienta o professor de Direito Liam Séamus O’Melinn (2011, p. 111), o Bardo nunca publicou um livro, e suas obras foram impressas logo após sua morte sem pagamento aos herdeiros. Tal fato pode contribuir para a escolha de obras, uma vez que significa uma redução nos preços da produção. Além disso, a celebração, em 2016, dos 400 anos da morte do dramaturgo gerou um aumento de publicações de obras relacionadas a Shakespeare visando a atender a demanda do mercado. Em Chicago, por exemplo, houve cerca de 850 eventos durante o ano todo (CHICAGO SHAKESPEARE THEATER, 2016).

\section{3 \\ Shakespeare estadunidense}

O próprio nome Shakespeare tornou-se um símbolo de qualidade que dá prestígio ao produto a ele atrelado. As professoras Kate McLuskie e Kate Rumbold (2014), por exemplo, destacam que a Consultoria Brand Finance declarou, em março de 2012, que Shakespeare era uma das marcas mais fortes no mundo, e seu valor monetário estaria em torno de 600 milhões de dólares. Esse resultado baseouse no quantitativo de venda de livros físicos e de downloads, no público de 
produções teatrais, nas receitas de produções para o cinema e para a televisão, no turismo e nos produtos associados ao nome do Bardo, entre outros. Tal fato parece ser confirmado por uma pesquisa realizada pela Rádio 4 da BBC em 1998, que elegeu Shakespeare como a personalidade britânica do milênio. Shakespeare teve 11.717 votos e derrotou políticos como Churchill e cientistas como Darwin (BBC, 1999). Tal escolha parece não estar associada ao valor estético das obras do dramaturgo, mas à relação entre o seu valor cultural e o econômico. Nessa relação, ao mesmo tempo que os produtos conectados a Shakespeare recebem o prestígio atribuído ao dramaturgo, eles contribuem para a manutenção da posição central do Bardo no polissistema cultural através de novas interpretações e valores produzidos. Em muitos casos, a participação de pessoas ou empresas é minimizada para que a presença de Shakespeare, e seu selo de valor, sejam destacados. McLuskie e Rumbold (2014) também salientam que a conexão entre o mundo de negócios (produção em massa) e a arte de Shakespeare, geralmente vinculada à cultura das classes privilegiadas, pode gerar uma tensão que é explorada criativamente, isto é, a ideia de transgressão, de provocação, produzida pelos contrastes garante o potencial de atualização do Bardo e a valorização do produto. Em srsly Hamlet, o enaltecimento de Shakespeare já é observado no fato de seu nome ser o primeiro em quase toda a obra (capa, folha de rosto e lombada). Além disso, na página do autor presente na adaptação, o Bardo é apresentado como o maior escritor da língua inglesa e o mais proeminente dramaturgo do mundo. Carbone, por outro lado, é retratada como sua colaboradora e como alguém que está tentando terminar uma piada sobre dois frequentadores de teatro. É interessante destacar que Julie Sanders (2006, p. 59) afirma que "[t]alvez uma maneira útil de se pensar sobre adaptação é como uma forma de escrita colaborativa através do tempo, e algumas vezes através da cultura ou língua" 56 .

$\mathrm{O}$ aspecto transgressor pode ser observado, além do próprio formato da adaptação, na dedicatória. Como já discutido no capítulo anterior, Carbone pede desculpas aos professores de Inglês. Entre as possíveis razões para tal pedido, podese considerar que as alterações (linguísticas e narrativas) em relação à obra de Shakespeare não condizem com uma visão mais acadêmica/canônica. Esse

\footnotetext{
56 "Perhaps a useful way of thinking about adaptation is as a form of collaborative writing across time, and sometimes across culture or language."
} 
destaque para a quebra do canônico pode ser uma estratégia para atrair os jovens leitores.

Em 2015, a fim de determinar a popularidade e a influência de Shakespeare, The British Council e parceiros promoveram uma pesquisa com 18.000 pessoas de 15 países e territórios. Os gráficos abaixo registram alguns dos resultados dessa pesquisa.

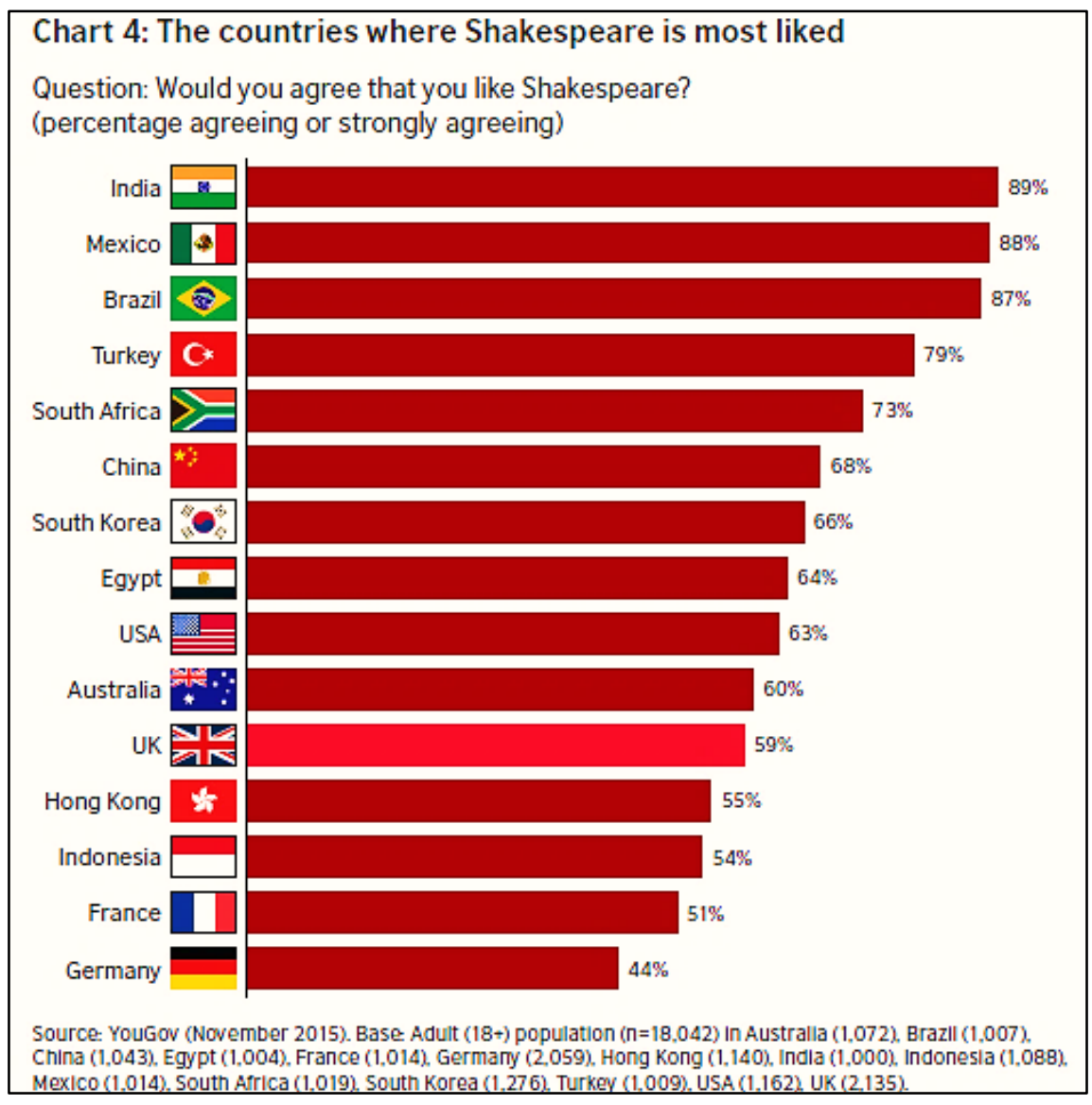

Gráfico 2 - Países que mais gostam de Shakespeare Fonte: DONALDSON, 2016. p. 10 


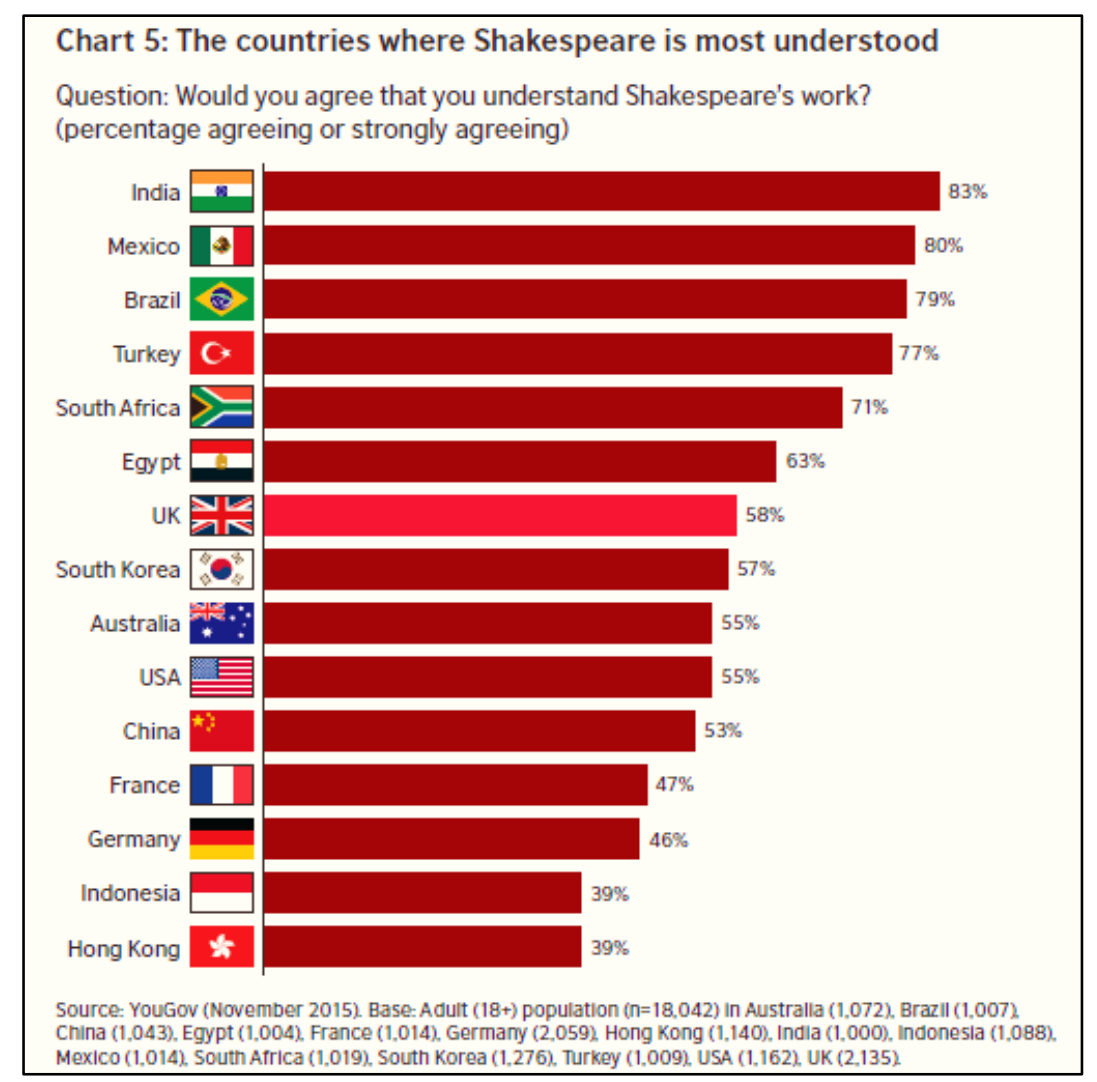

Gráfico 3 - Países onde Shakespeare é mais compreendido Fonte: DONALDSON, 2016. p. 11

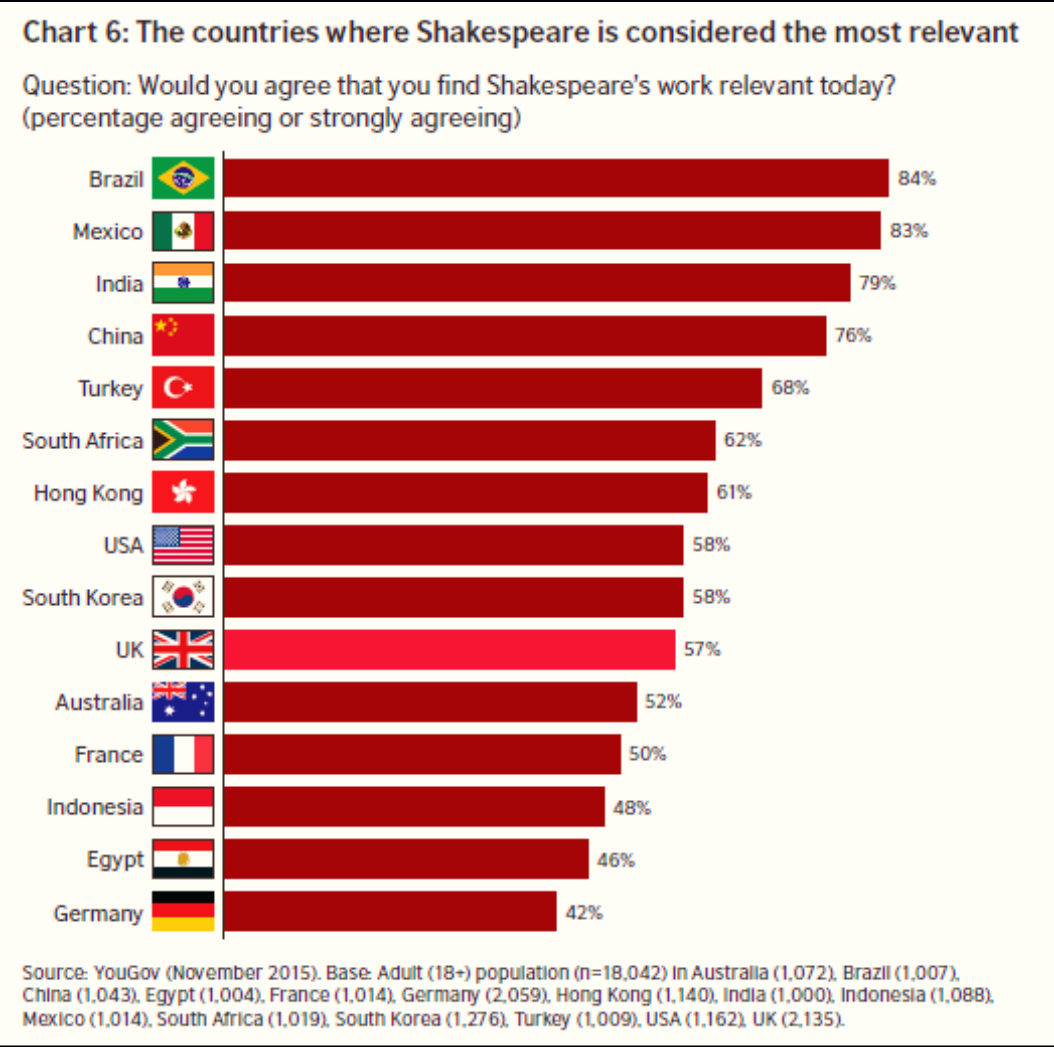

Gráfico 4 - Países onde Shakespeare é considerado mais relevante Fonte: DONALDSON, 2016. p. 11 
Com base nos resultados observados nos gráficos, é possível dizer que Shakespeare é geralmente mais valorizado em países onde o inglês não é a língua oficial. Tal acontecimento pode estar relacionado às imagens de Shakespeare e de suas obras que são produzidas em diferentes culturas. Tal fato fica claro em outro momento da pesquisa. Enquanto $70 \%$ dos entrevistados no Reino Unido estudaram as obras do dramaturgo no colégio ou na universidade, nos outros países, somente $30 \%$ dos entrevistados tiveram contato com Shakespeare através do meio acadêmico. Cerca de 19\% dos participantes da pesquisa conheceram Shakespeare através de traduções, e $46 \%$ deles já viram filmes baseados nas peças. O percentual relacionado à apreciação do dramaturgo parece ser maior entre aqueles que viram filmes ou peças de teatro e menor naqueles cujo contato foi acadêmico. É possível, então, afirmar que as imagens geradas pelas reescritas podem contribuir de forma significativa para a recepção de Shakespeare e suas obras.

Com relação aos Estados Unidos, tendo por base o resultado da pesquisa, as imagens de Shakespeare e de suas peças parecem produzir uma visão relacionada a um certo grau de dificuldade e à pouca relevância. Para se entender esse resultado, é necessário discutir a possível perspectiva estadunidense a respeito de Shakespeare. O historiador e acadêmico Lawrence W. Levine (1984) salienta que desde a primeira apresentação documentada de uma peça do Bardo (1750) e por toda a primeira metade do século XIX, Shakespeare foi o dramaturgo mais popular nos Estados Unidos. Segundo Levine, o teatro da época era um espaço democrático e heterogêneo, voltado para todas as classes e grupos, e Shakespeare era uma diversão popular. A peça, em geral, era a atração principal da noite, mas havia também uma variedade de outras atrações (danças, farsas etc.). O público, assim como na era elisabetana, conhecia as peças de Shakespeare e participava literalmente delas. Essa familiaridade com as peças pode estar relacionada não só à grande oferta de apresentações, mas também ao costume de se memorizar textos de Shakespeare nas salas de aula do período.

As imagens das obras no período foram construídas pelas reescritas vindas da Inglaterra, mas, principalmente, pelas produzidas nos Estados Unidos. Tais adaptações buscavam destacar nas peças aquilo que espelhava as crenças estadunidenses. Tal fato é um claro exemplo do poder da reescrita apresentado por Lefevere. Enquanto a obra literária mantém-se canonizada, a interpretação muda, 
ou seja, o trabalho é reescrito para se adequar às características poéticas dominantes e aos parâmetros da patronagem (LEFEVERE, 2017, p. 14).

Os americanos do século XIX foram capazes de encaixar Shakespeare tão facilmente na sua própria cultura porque ele parecia se encaixar - porque muitos dos seus valores e gostos eram, ou pelo menos pareciam ser, próximos aos dos deles, e eram apresentados através de figuras que pareciam reais e se tornaram importantes para o público. ${ }^{57}$ (LEVINE, 1984, p. 50)

A americanização e valorização de Shakespeare não ocorreu apenas em termos de apresentações teatrais. O Bardo era um grande potencial para o mercado editorial. $\mathrm{O}$ escritor e historiador francês Alexis de Tocqueville, por exemplo, ao discutir sobre a literatura nos Estados Unidos após uma viagem feita em 1831, ressalta que há uma grande quantidade de obras nas "lojas dos livreiros". Segundo ele, a maioria foi composta na Europa, mas impressa e adaptada no país norteamericano. Tocqueville acrescenta que as obras inglesas são quase todas publicadas nos Estados Unidos e, ao falar sobre Shakespeare, afirma que

[o] gênio literário da Grã-Bretanha ainda projeta seus raios até o fundo das florestas do novo mundo. Não há cabana de pioneiro em que não se encontrem alguns volumes avulsos de Shakespeare. Lembro-me de ter lido pela primeira vez o drama feudal de Henrique V numa log-house. (TOCQUEVILLE, 2000, p. 63-64)

Lawrence Levine destaca que a partir da segunda metade do século XIX a relação de Shakespeare com o público estadunidense começou a se alterar gradativamente. As obras do dramaturgo passaram a fazer parte da cultura erudita, e o Bardo deixou de pertencer a todos os grupos para ser visto como pretensioso e irrelevante. Suas obras passaram a ter a função de "esclarecer as pessoas comuns, que deveriam engoli-lo não para o seu entretenimento, mas para sua educação, como uma pausa - não como uma parte normal - de sua dieta cultural habitual" 58 (LEVINE, 1984, p. 47). Para o historiador, tal alteração pode estar relacionada à desvalorização da oratória (com o crescimento do letramento), ao aumento de

\footnotetext{
57 "Nineteenth-century Americans were able to fit Shakespeare into their culture so easily because he seemed to fit-because so many of his values and tastes were, or at least appeared to be, close to their own, and were presented through figures that seemed real and came to matter to the audience."

58 "He had become the possession of the educated portions of society who disseminated his plays for the enlightenment of the average folk who were to swallow him not for their entertainment but for their education, as a respite from- not as a normal part of-their usual cultural diet."
} 
imigrantes que não tinham o inglês como língua materna, à separação de teatros e espetáculos de acordo com o público e a uma maior hierarquização cultural.

Pode-se dizer que srsly Hamlet, de certa forma, busca trazer o Shakespeare do século XIX para os jovens do século XXI. Carbone tenta criar uma obra com a qual o público possa se identificar e onde a diversão e a oralidade façam parte da construção de sentido. Como já mencionado em outra seção, a imitação do formato de mensagens digitais pode ser vista como uma tentativa não só de reproduzir um maior engajamento do público com a obra (embora ele não seja real), mas também de aproximar a adaptação à vivência dos leitores. Torna-se possível, assim, afirmar que a aproximação de srsly Hamlet com a visão estadunidense de Shakespeare do século XIX possibilita trazer também as características das peças shakespearianas da era elisabetana.

\section{4 \\ O sistema educacional}

É possível dizer, então, que Shakespeare, a partir do século XX, apesar de manter a sua posição canonizada, passou a ser relacionado à cultura das classes privilegiadas e ao sistema educacional estadunidense. Um exemplo dessa relação é encontrado em The Common Core State Standards for English Language Arts \& Literacy in History / Social Studies, Science, and Technical Subjects. Embora os currículos educacionais nos Estados Unidos sejam determinados localmente, essa base curricular comum complementar, não mandatória, foi lançada em 2010. Esses parâmetros são adotados em 41 estados, no distrito federal e em quatro territórios. O fato de Shakespeare ser mencionado em diversos momentos do texto mostra claramente o valor dado ao dramaturgo na educação dos Estados Unidos. Na passagem abaixo, o Bardo é um dos poucos conteúdos mencionados e é posicionado no mesmo patamar da mitologia e de documentos que formam a base do país.

Os Parâmetros definem o que se espera que os alunos saibam e sejam capazes de fazer, [...]. Além disso, enquanto os Parâmetros fazem referências a algumas formas particulares de conteúdo, incluindo mitologia, documentos fundamentais dos Estados Unidos, e Shakespeare, eles não enumeram - na verdade, não podem - todo 
ou até mesmo a maioria do conteúdo que os estudantes devem aprender. ${ }^{59}$ (NGA CENTER; CCSSO, 2010, p. 6)

Ao discutir a preparação para a faculdade e para a carreira, o documento afirma que os alunos devem lidar com obras que sirvam de modelos para o pensamento e para a escrita e acrescenta que a escolha dos textos deve envolver trabalhos contemporâneos de alta qualidade e "documentos americanos edificantes, os clássicos da literatura norte-americana e as peças atemporais de Shakespeare" 60 (NGA CENTER; CCSSO, 2010, p. 35). Claramente se percebe que Shakespeare é visto, por instituições oficiais, como parte da cultura americana erudita e essencial para a formação do cidadão. Como já tinha sido observado quando se discutiram as expectativas em relação à literatura infantil, a editora PRH procura trazer um aspecto pedagógico para a série. Nas atividades propostas fornecidas pelo site (Anexo A), que são iguais para as quatro obras da série, há uma ênfase na natureza midiática de $O M G$ Shakespeare. Entre as sugestões tem-se a localização de termos próprios da mídia digital, análise de emojis, produção de tweets e a comparação de cenas com a peça de Shakespeare e com filmes. Parece haver uma maior ênfase no que diferencia a adaptação da peça do que na discussão sobre as possíveis interpretações.

\section{5 \\ Os emojis estadunidenses}

Uma vez que a adaptação analisada nesta dissertação faz uso de emojis na construção de seus sentidos, é importante discutir o papel desse código comunicativo na cultura estadunidense.

O professor de semiótica Marcel Danesi, em seu livro A semiótica do Emoji, explica que o termo emoji é uma adaptação em inglês da palavra japonesa 絵文字. O "e" significa "imagem" e "moji" pode ser traduzido como "letra, caracter". Os primeiros emojis foram criados no final da década de 1990 por Shigetaka Kurita,

\footnotetext{
59 "The Standards define what all students are expected to know and be able to do, [...]. Furthermore, while the Standards make references to some particular forms of content, including mythology, foundational U.S. documents, and Shakespeare, they do not —indeed, cannot — enumerate all or even most of the content that students should learn."

60 "Along with high-quality contemporary works, these texts should be chosen from among seminal U.S. documents, the classics of American literature, and the timeless dramas of Shakespeare."
} 
um funcionário de uma empresa de telecomunicações japonesa, para substituir o estilo dos emoticons (caracteres tipográficos). Eram apenas 176 emojis. Em 2011, a Apple lançou emojis no seu Sistema Operacional Cinco (iOS5) e, a partir daí, eles se tornaram um fenômeno mundial. A importância desses pictogramas é tão grande que no dia 17 de julho se comemora o Dia Mundial do Emoji (DANESI, 2017, p.1$3)$.

Apesar de ter surgido no Japão, é possível afirmar que o emoji é um fenômeno dos Estados Unidos. A escolha dos pictogramas que se tornam oficiais e podem ser empregados nas plataformas é feita pela Comissão do Consórcio UNICODE, que determina um padrão de codificação universal de caracteres. Destacam-se como membros votantes as empresas Facebook, Apple, IBM, Microsoft, Google, Adobe, Huawei, a Universidade Berkeley (Califórnia), a Emojipedia, a Monotype e membros do governo da Índia, Bangladesh e Omã. Observa-se que grande parte são companhias norte-americanas e, embora o objetivo do UNICODE seja uma padronização que garanta uma universalização, não se pode eliminar a influência dos Estados Unidos. O professor de Linguística Vyvyan Evans (2017, p. 29) cita como exemplo desse predomínio o fato de que, em 2015, a maioria dos emojis relacionados à comida refletiam a cultura estadunidense. Atualmente, de acordo com o site da UNICODE, existem 3.019 emojis oficiais.

Uma pesquisa feita com falantes de 16 línguas entre outubro de 2014 e janeiro de 2015 analisou mais de 1 bilhão de usos de emojis em aplicativos Android e iOS. De acordo com o resultado, a população estadunidense foi a que mais usou esses pictogramas no período. Como curiosidade, também foi a que empregou o dobro de pictogramas relacionados à realeza (coroa e princesa) em relação aos britânicos (SWIFTKEY, 2015). Além do fato de o ano de 2015 indicar um uso significativo de emojis no mundo, Evans (2017, p. 11) destaca o prestígio que eles alcançaram quando a Oxford University Press escolheu o pictograma do rosto com lágrimas de alegria como a Palavra do Ano do Dicionário Oxford. A escolha baseou-se nos resultados da pesquisa do Swiftkey mencionada acima, que indica que ele corresponde a 20\% do total dos emojis usados no Reino Unido e a 17\% nos Estados Unidos naquele ano. Os editores dos dicionários acrescentam que o pictograma 
reflete "o comportamento, o humor e as preocupações de 2015"61 (OXFORD UNIVERSITY PRESS, 2015). A controvérsia gerada pela escolha de um elemento que, na realidade, não é uma palavra apenas ampliou-se com o resultado. Kyle Smith publicou, em outubro de 2015, um artigo intitulado "Emojis are ruining civilization" (“Emojis estão destruindo a civilização”). De uma forma irônica, ele apresenta vários exemplos do que ele considera um retrocesso. Entre eles, a tradução de quatro peças de Shakespeare com o uso de emojis "porque obviamente não se perderá nuance alguma com 'OMG Shakespeare"” ${ }^{62}$ (SMITH, 2015). Em um artigo no The Guardian, o crítico de arte Jonathan Jones afirma que esses pictogramas estão arrastando a humanidade para a Idade das Trevas e acrescenta: "Fale emoji se você quiser. Eu vou me manter fiel à língua de Shakespeare" 63 (JONES, 2015).

Merece destaque o fato de que, ao mesmo tempo que a patronagem controla a padronização e valorização dos emojis, as demandas sociais e culturais contribuem para a construção e/ou alteração desses pictogramas. Em 2015, a Apple mudou seu emoji de arma de fogo para uma pistola de água por pressões de grupos nos Estados Unidos que defendem o controle de armas. Outras plataformas seguiram esse modelo nos anos seguintes. Outro exemplo ocorreu em 2017. A partir de uma discussão no Twitter sobre a posição correta dos ingredientes no emoji “hambúrguer", o Google alterou a posição do queijo no Android 8.1.

O uso dos pictogramas também interfere na produção de sentidos e no conceito de comunicação da cultura na qual são empregados. Em janeiro de 2015, por exemplo, um adolescente foi preso por ter postado no Facebook conteúdo considerado como uma ameaça à Polícia de Nova York. Na mensagem havia o emoji da cabeça de um policial seguido de três ícones de pistola (EVANS, 2017, p. 38). No mesmo ano, os advogados de um homem acusado de venda de produtos ilegais através de um site insistiram na inclusão de um smiley presente na mensagem como parte das provas (WEISER, 2015).

\footnotetext{
61 "There were other strong contenders from a range of fields, outlined below, but " as the 'word' that best reflected the ethos, mood, and preoccupations of 2015."

62 "Four of Shakespeare's plays have been translated into emojis, because obviously you won't lose any nuance with 'OMG Shakespeare'."

63 "Speak Emoji if you want. I'll stick with the language of Shakespeare."
} 
Como Danesi (2017) salienta, e os exemplos acima parecem confirmar, os emojis oferecem nuances de significação no texto digital informal, tido como emocionalmente pobre. Segundo o professor, esses pictogramas fundamentados na iconicidade apresentam duas funções: uma fática (manter as interações amigáveis) e uma emotiva. A função emotiva dos emojis pode funcionar como substituta para as expressões faciais e gestuais e para reforçar um ponto de vista (recursos paralinguísticos). Apesar da tentativa de padronização, assim como na linguagem verbal, o sentido dos pictogramas não é único ou estável. É impossível evitar a ambiguidade e a codificação cultural no emprego dos emojis, tudo depende do contexto. Além das variações de interpretação causadas por diferenças culturais e situacionais, há também questões tecnológicas. Esses pictogramas apresentam diferenças entre os sistemas operacionais, o que pode alterar seus possíveis sentidos. Os exemplos abaixo são do código UNICODE v.13.0. É possível observar que o rosto com lágrimas do Facebook, por estar com a boca mais aberta, parece enfatizar mais a emoção transmitida. Com relação ao nerd, o emoji do Google transmite uma alegria que não está presente nos outros. A presença de apenas dois dentes no da Apple, do Windows e da Samsung parece reforçar o estereótipo do nerd (não atraente, excêntrico, tímido).

\begin{tabular}{|c|c|c|c|c|c|}
\hline APPLE & GOOGLE & FACEBOOK & WINDOWS & SAMSUNG & \\
\hline & & & & 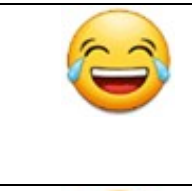 & $\begin{array}{c}\text { Rosto } \\
\text { com } \\
\text { lágrimas } \\
\text { de } \\
\text { alegria }\end{array}$ \\
\hline (0) & & & & (1) & $\begin{array}{l}\text { Rosto } \\
\text { de } n e r d\end{array}$ \\
\hline
\end{tabular}

Quadro 1 - Emojis em diferentes plataformas Fonte: UNICODE, 2020

A obra de Carbone faz uso dos emojis da Apple. Ao invés de criar pictogramas específicos para o texto, a opção foi utilizar elementos padrão e aprovados oficialmente. Tal decisão pode ser vista como uma tentativa de facilitar a compreensão do texto, uma vez que o emprego de pictogramas novos poderia gerar mais ambiguidade. Um fator que pode ter contribuído para escolha dos emojis da Apple é o prestígio que o iPhone desfruta entre os adolescentes nos Estados 
Unidos. Uma pesquisa divulgada em 2014 revela que $67 \%$ dos adolescentes possuem um iPhone e $73 \%$ dos participantes esperam que seu próximo celular seja da Apple (JONES, 2014). A opção pelos pictogramas da companhia pode ser uma estratégia para promover a identificação dos jovens com a obra e uma forma de valorizar a própria adaptação, associando-a ao sonho de consumo da juventude estadunidense. 


\section{4}

\section{História e narrativa: continuações e transformações

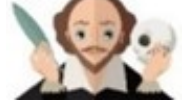

Já foi mencionado anteriormente que esta dissertação tem como parâmetro para a análise de srsly Hamlet o primeiro volume da obra The Arden Shakespeare: Hamlet, publicada em 2016. Trata-se da terceira edição da série e foi editada e revisada por Ann Thompson e Neil Taylor. A escolha dessa obra como texto-fonte baseia-se no reconhecimento da série no meio acadêmico, principalmente por causa dos nomes a ela associados. A primeira edição da série (Hamlet), por exemplo, foi editada por Edward Dowden, um dos mais conhecidos críticos shakespearianos, e publicada em 1899. Um outro fator que contribuiu para a seleção da série da editora Bloomsbury foi a proximidade da data de sua publicação com a de srsly Hamlet (2015). As duas obras parecem estar associadas às comemorações dos 400 anos da morte do Bardo.

Embora The Arden Shakespeare Hamlet seja constituída por dois volumes, que trazem os três textos impressos da peça mais conhecidos $(Q 1, Q 2$ e Folio), este estudo irá trabalhar com o texto que se baseia no Segundo Quarto (1604-5), presente no primeiro volume. Os próprios editores reconhecem que o $Q 2$ apresenta um status mais elevado por ser considerado derivado de um manuscrito de Shakespeare, por ter sido publicado não muito depois de a peça ter sido encenada, e por, presumivelmente, ter o consentimento do Bardo para a publicação (SHAKESPEARE, 2016, p. 12). Embora o texto pareça estar bem próximo daquele que foi escrito por Shakespeare, Thompson e Taylor também salientam que o Segundo Quarto, por ser muito longo, aproxima-se mais da leitura do que das apresentações teatrais.

Este capítulo busca discutir a relação entre a adaptação e o texto-fonte através da análise de certos elementos narrativos e linguísticos. Procura também verificar se o gênero do texto e a perspectiva de um determinado público-alvo interferiram nas escolhas feitas.

Quando discuti o conceito de adaptação no segundo capítulo desta dissertação, salientei que as adaptações podem se aproximar da prática editorial (redução ou ampliação) e/ou também podem ser uma tentativa de atualizar os 
textos-fonte e torná-los mais próximos e relevantes para novas audiências (SANDERS, 2006, p. 22). Zohar Shavit (1986, p. 125) destaca que a literatura voltada para crianças e jovens também busca, em geral, a simplificação e a redução. Na série $O M G$ Shakespeare, a aproximação do texto com a geração do mundo digital é divulgada de forma explícita pela própria $P R H$. A prática de redução é claramente vista pelo número de palavras nos dois textos. O segundo Quarto, reproduzido em The Arden Shakespeare: Hamlet, tem 28.628 palavras (SHAKESPEARE, 2016, p. 567). Além de ser considerada a mais longa peça de Shakespeare, o personagem Hamlet é o que possui mais falas (11.610 palavras), de acordo com Kevin Lynch, editor do Guinness online (2014). A adaptação de Carbone tem cerca de 6.738 palavras e 779 emojis e fotografias, e Hamlet enuncia aproximadamente 2.118 palavras.

A téorica Linda Hutcheon (2013, p. 6) afirma que várias teorias da adaptação consideram que a história é o denominador comum daquilo que é transposto para diferentes mídias e gêneros. Julie Sanders (2016, p. 57), ao falar sobre adaptações e apropriações, acrescenta que elas “dependem do cânone literário para a provisão de um repositório compartilhado de enredos, temas, personagens e ideias sobre as quais suas variações criativas podem ser feitas" ${ }^{64}$.

\section{1 Elementos extratextuais e metatextos}

Embora o objetivo desta dissertação seja a discussão da parte textual da obra, algumas considerações sobre elementos extratextuais (capa e contracapa) e diferenças nas partes pré- e pós-textuais entre os dois livros merecem ser mencionadas.

A escolha de uma capa faz parte de um processo ideológico e econômico. É interessante destacar que, ao contrário de capas mais tradicionais da peça, que mostram o personagem Hamlet, a capa do volume do Segundo Quarto de Hamlet da Arden Shakespeare (2006) apresenta uma fotografia em preto e branco, de Ofélia:

\footnotetext{
64 "Adaptation and appropriation are dependent on the literary canon for the provision of a shared repository of storylines, themes, characters and ideas upon which their creative variations can be made."
} 
morta, embaixo da água, vestindo uma bata e segurando na sua mão esquerda, um ramo de flores, perto de sua virilha, em uma área de sua bata escondida por sombras. A cabeça de Ofélia não aparece completamente na fotografia; uma faixa preta no topo da capa com o título "The Arden Shakespeare" corta seu rosto [...] ${ }^{65}$ (BURT, 2012, p. 235)

Observa-se, então, que a ideia de morte, simbolizada pela caveira nas capas de Hamlet, também está presente nessa edição da Bloomsbury. Trata-se de um corpo em uma foto sem cor carregando flores aparentemente murchas. Contudo, outros aspectos são agregados à capa da publicação de 2006. Em sua Introdução, os editores da obra, Thompson e Taylor, baseados no filósofo francês Gaston Bachelar, destacam a conexão simbólica entre mulheres, elementos líquidos (sangue, leite, lágrimas etc.) e morte. Os editores também recorrem à crítica e feminista Elaine Showalter ao afirmar que Ofélia "representa um arquétipo poderoso no qual insanidade feminina e sexualidade feminina encontram-se inexoravelmente interligados" $" 66$ (SHAKESPEARE, 2016, p. 26-27). Embora os editores discutam os estereótipos relacionados à sexualidade, à melancolia e à loucura das personagens femininas da peça shakespeariana, a capa de sua obra apenas os reforça. A Ofélia apresentada é vitimizada, sem identidade, e tem sua sexualidade associada à escuridão. É possível que essa capa tenha gerado críticas negativas. Essa pode ser uma provável explicação para a mudança de capa na edição revisada de 2016. No lugar de Ofélia, encontramos a foto colorida e indistinta do espectro do rei.

A capa de srsly (seriously), por outro lado, traz rupturas de padrões. A abreviação no título da adaptação de Carbone parece indicar uma quebra de formalismo, já que, embora tenha surgido no século XVIII, essa palavra é geralmente relacionada à linguagem da internet. $\mathrm{O}$ uso de minúsculas nos nomes dos autores também pode ser considerado uma tentativa de romper com os paradigmas editoriais. O título da obra, uma das principais citações da peça e comentários sobre a obra (na contracapa) aparecem em balões de fala, numa mistura de inglês e pictogramas. O leiaute com emojis e balões de fala (fundo da capa,

\footnotetext{
65 “ [...] the dead Ophelia, underwater, dressed in a smock and holding in her left hand, a branch with flowers, near her crotch, in a shadowy area of her smock. Ophelia's head is not fully in the shot; a black band at the top of the cover branding the book "The Arden Shakespeare" crops her face $[\ldots] . "$

66 "[...] represents a powerful archetype in which female insanity and female sexuality are inextricably intertwined."
} 
lombada e contracapa) pode ser visto como uma tentativa de reforçar a ideia de comunicação em uma nova mídia e para um público jovem. A foto, na capa, de um casal com roupas de época segurando um celular e com emojis cobrindo o rosto completa a visão de uma obra lúdica e que combina o contemporâneo com o clássico. Cabe mencionar que, embora Shakespeare seja mencionado primeiro, indicando uma possível hierarquia, o nome de Carbone é ligado ao do Bardo através do símbolo da adição (+). O título e a menção aos dois "autores" parecem já indicar que a obra é uma reescrita. Tal fato é reforçado na ficha catalográfica, onde a obra é caracterizada como adaptação.

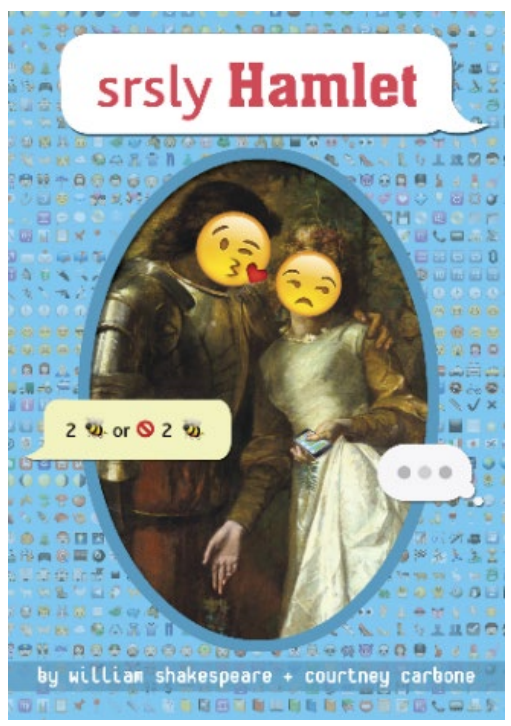

Figura 6 - Capa de srsly Hamlet Fonte: SHAKESPEARE; CARBONE, 2015

Também é interessante destacar que o anterrosto (falsa folha de rosto) e a folha de rosto na obra de Carbone apresentam um fundo preto, um emoji de caveira e um smiley na cor preta sorrindo (no anterrosto). O fundo preto pode reforçar a ideia de morte que a cor traz, mas também pode buscar uma aproximação com o leitor jovem, uma vez que essa cor também é vista pelos jovens como um símbolo de rebeldia (CHEN, 2009, p. 234). O preto da roupa de Hamlet, que representa seu luto e sua revolta contra o casamento da mãe, passa para as folhas do livro na adaptação. A presença da caveira nessas páginas não só remete à morte, um dos temas constantes da peça, mas também à cena do cemitério (V.i), um símbolo da peça de Shakespeare. 
Com relação à parte pré-textual, a obra editada por Thompson e Taylor, além do sumário e de dois prefácios de autoria dos editores, exibe uma página onde identifica esses editores e uma introdução que, entre outras coisas, aborda, em termos históricos, as prováveis fontes da história e data da criação do Hamlet shakespeariano, as produções de Hamlet em diferentes mídias e épocas, a edição das publicações, o papel dos solilóquios e algumas das possíveis interpretações do texto. A obra também contém uma seção intitulada "Additions and Reconsiderations” (“Adições e Reconsiderações”), onde não só cita as mudanças em termos de biografia, estudos textuais e crítica, mas também fala sobre encenações e adaptações (literárias e cinematográficas) que ocorreram desde a primeira publicação dessa edição (2006). Srsly Hamlet, por outro lado, não possui sumários, prefácios ou introduções. A página do autor, colocada na parte póstextual, já foi discutida na seção 3.3 desta dissertação.

A parte pós-textual do Hamlet da Arden Shakespeare compreende cinco apêndices seguidos de uma lista de abreviações e referências e de comentários e notas de pé de página. Os dois primeiros apêndices trazem trechos do Folio e mais informações sobre os textos presentes nos dois volumes da série (os Quartos e o Folio). Os demais Apêndices apresentam comentários sobre as músicas da peça, sobre convenções editoriais, sobre a possibilidade de os atores desempenharem mais de um papel na peça shakespeariana e sobre as controvérsias existentes a respeito das divisões em atos e cenas.

A adaptação de Carbone também traz uma lista de 26 abreviações na parte pós-textual, mas ao contrário daquelas incluídas no Hamlet da Bloomsbury, elas são coloquiais. Há também uma lista com 33 emojis que indicam emoções. Nenhuma referência à fonte do texto ou a escolhas editoriais é feita.

É interessante notar que, enquanto Thompson e Taylor enfatizam questões acadêmicas, Carbone traz as significações da linguagem visual e do inglês informal para a sua obra. Na adaptação, pouco é falado sobre Shakespeare e sua peça; a ênfase é dada justamente aos elementos que afastam srsly Hamlet do texto-fonte. Pode-se dizer que o texto de Carbone, embora destaque a importância de Shakespeare, não busca salientar a posição canônica da obra ou seu valor estético, mas torná-la mais próxima dos leitores. 
Um outro fator que merece ressalva é a questão comercial. No livro da série The Arden Shakespeare há uma página (pré-textual) com uma lista de todas as obras da série. Em srsly Hamlet, a divulgação é bem maior. Além da referência ao site para jovens onde outras obras da editora podem ser encontradas, as dez páginas finais do livro apresentam passagens das outras três obras da série $O M G$ Shakespeare. Esse aspecto parece reforçar o valor econômico de Shakespeare.

\section{2}

\section{As possíveis influências nos Hamlets de Shakespeare e de Carbone}

Como mencionei anteriormente, o Bardo era um criativo adaptador. A pesquisadora Marlene Soares dos Santos (2016a, p. 16-17) destaca que Shakespeare e grande parte dos dramaturgos elisabetanos "para escreverem seus enredos, recorriam a narrativas de procedências diversas: lendas, mitos, romances gregos e de cavalaria, literatura clássica e contemporânea, contos populares e eruditos". O estudioso Marvin Hunt (2007, p. 13) destaca que o primeiro registro de Hamlet "foi escrito em latim pelo historiador dinamarquês Saxo Grammaticus durante o século XII" e encontra-se na obra Historiae Danicae. Assim, a história de Amleth ou Amlethus, que fingiu loucura para obter vingança contra o tio/padrasto (assassino do pai de Amleth) e que acabou matando um dos conselheiros do tio, tem sua origem no folclore dinamarquês (FILIPSKI, 2013, p. 1-3). Essa história é adaptada para o francês por François de Belleforest em 1570. Como a tradução para o inglês da obra de Belleforest só foi publicada em 1608, a possibilidade de que ela tenha influenciado Shakespeare é tênue. Pode-se, no entanto, elencar nas histórias de Amleth e de Hamblet vários elementos também presentes na peça do Bardo: traços de alguns personagens principais, a loucura como disfarce, a vingança contra o assassino do pai, o casamento incestuoso e imagens relacionadas à putrefação (HUNT, 2007, p. 13-21).

Uma possível fonte imediata do Hamlet shakespeariano é uma peça perdida da década de 1580 batizada pelos acadêmicos de Ur-Hamlet. Acredita-se que o provável autor dessa peça seja Thomas Kyd (1558-1594). Essa tragédia de vingança, embora muito aclamada nos palcos londrinos no início da carreira de Shakespeare, nunca foi publicada. Apesar das poucas evidências a respeito dessa 
peça, pode-se afirmar que sua história trazia um fantasma que demandava vingança (HUNT, 2007).

Merece destaque que, entre 1597 e 1604, as tragédias de vingança eram famosas nos teatros de Londres. Uma das tragédias mais populares do período é outra obra de Thomas Kyd, A Tragédia Espanhola. É plausível afirmar que a peça de Kyd e o Hamlet de Shakespeare compartilham vários elementos: "um assassinato secreto, um fantasma, exigências de vingança, fingimento da loucura, a loucura verdadeira de uma personagem feminina, a hesitação e a autocensura do herói" (HUNT, 2007, p. 23), a peça dentro da peça, os solilóquios e a morte do personagem principal.

Pode-se dizer, portanto, que Shakespeare fez uso dos elementos dramáticos comuns e populares na sua época para criar uma obra única. É possível declarar também que, em vários momentos, o Bardo rompeu com as convenções da peça de vingança com o objetivo de ampliar os sentidos de sua obra e tornar seu protagonista mais humano. Courtney Carbone, em srsly Hamlet, manteve os temas e recursos usados por Shakespeare, mas, como o Bardo, procurou produzir uma obra que, ao mesmo tempo, pudesse soar familiar e que trouxesse novas experiências para leitores de sua própria época.

A relação de Shakespeare com as demandas e costumes de sua audiência vai além das possíveis fontes das tragédias de vingança. O Bardo era um contador de histórias criativo e fazia uso de tradições orais e escritas para criar suas peças e para ampliar os vínculos com o público. Julie Sanders destaca que sua "obra funciona de uma maneira notavelmente semelhante às formas de arte comuns, compartilhadas, transacionais, transculturais e frequentemente transnacionais dos mitos e contos de fadas" ${ }^{67}$ (SANDERS, 2016, p. 58). É plausível considerar que Shakespeare fez uso em suas peças, de forma consciente ou não, de modelos presentes em contos folclóricos e de fantasia comuns na época. Deve-se ter em mente que na era elisabetana as habilidades de leitura da maioria da população eram muito limitadas ou inexistentes. Assim, a diversão para esse público ainda se baseava na oralidade, nas histórias contadas para passar o tempo. Destaca-se também que os chapbooks,

\footnotetext{
67 " [...] the playwright whose oeuvre functions in a remarkably similar way to those communal, shared, transactional, transcultural and frequently transnational art forms of myth and fairy tale: William Shakespeare."
} 
que eram populares nessa época, traziam vários contos de fada, e que esses não eram associados ao mundo infantil. Como foi apresentado no segundo capítulo desta dissertação, os contos de fada eram destinados a adultos. Somente na metade do século XIX tais contos foram considerados adequados para os jovens leitores, e $o$ aspecto moral foi mais enfatizado.

Assim, torna-se aceitável discutir a possibilidade de que, além dos objetivos educacionais, a presença de características geralmente associadas aos contos de fadas (enredos, temas, personagens etc.) possa ser um fator que influencia as escolhas feitas nas adaptações das peças shakespearianas, principalmente as voltadas para o público infantil. Embora o modelo dos contos de fadas seja mais facilmente identificável em outras peças do Bardo, esta dissertação discute pontos em comum entre Hamlet e esse gênero. Dentro desta perspectiva, a significação da peça ganha novas camadas, vinculadas ao emocional e ao psicológico. Todos os elementos que podem ser associados aos contos de fadas parecem estar igualmente presentes em srsly Hamlet. Tal fato pode ser visto não só como o desejo de manter as características do texto-fonte, mas também como uma forma de evidenciar os elementos que formam a estrutura dos livros voltados para crianças e adolescentes.

Em ambas as obras, o público/leitor é introduzido à natureza mágica e misteriosa do mundo mesmo antes de conhecer o protagonista da história. A dúvida a respeito da identidade do soldado que chega para a vigília, a troca da guarda, o horário que indica a transição de um dia para outro e a aparição de um fantasma já transmitem uma ideia de um lugar e um tempo intermediários, entre a realidade e a fantasia. Cria-se, então, a atmosfera onírica e indistinta dos contos de fadas.

A fim de elencar os elementos dos contos de fadas presentes na peça shakespeariana e na adaptação, este estudo baseia-se nas características do gênero apresentadas pelo professor Steven Swann Jones na obra intitulada The Fairy Tale: the Magic Mirror of Imagination (2002). Como primeiro traço, destaca-se o fato de os personagens, descritos de forma genérica, serem pessoas comuns que lidam com problemas do cotidiano (relações com membros da família, regras sociais, perda, vingança etc.). Hamlet é um príncipe sem coroa ou magia, mas querido pelo povo. São suas fraquezas e dilemas que tornam possível a identificação com ele. Como nos contos, trata-se de uma boa pessoa que tem que lidar com questões difíceis. Como Fortimbrás afirma, "[...] he was a good egg. ๑ Scrambled, but good" ([...], 
no frigir dos ovos, ele era um cara legal. ( Desorientado, mas bom") (SHAKESPEARE; CARBONE, 2015, p. 101).

O primeiro ato, tanto na peça quanto na adaptação, traz vários elementos que são constantes nos contos de fadas. A indicação de um local distante e uma época indefinida, a presença da realeza, a quebra da estabilidade gerada pela perda do rei/pai, o respeito aos pais verdadeiros (Hamlet e o pai/ Laerte, Ofélia e Polônio) e o conflito com o padrasto/tio são apresentados nas primeiras cenas. Na adaptação, a indefinição espacial e temporal fica ainda mais marcada. Na passagem abaixo, a noção de tempo e espaço torna-se fluida não só pela representação da plataforma digital (fora da realidade), mas também pela comunicação entre o filho vivo e o pai morto. O pedido feito pelo pai/fantasma para ser lembrado e para a mãe não ser punida por ter se casado com Cláudio pode ser considerado como exemplo dos valores morais geralmente transmitidos. Neste caso, trata-se da obrigação filial de honrar e proteger os pais.

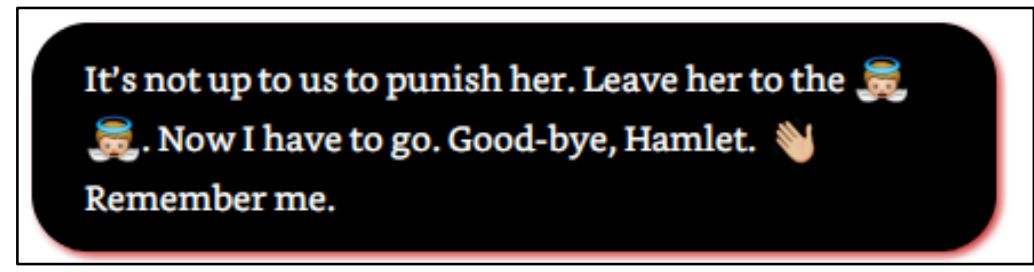

Figura 7 - Sem conflitos com os pais ${ }^{68}$ Fonte: SHAKESPEARE; CARBONE, 2015, p. 26

Jones (2002) também ressalta que, embora sejam chamados de contos de fadas, não é necessário que haja fadas no enredo, mas deve haver a interação do protagonista com elementos mágicos e/ou misteriosos que irão introduzir um problema/uma tarefa. Como visto na passagem acima, o fantasma traz o elemento sobrenatural e, possivelmente, dos sonhos/inconsciente. Segundo Jones, esse aspecto mágico deve ser considerado verdadeiro, natural. Portanto, tanto na peça quanto na adaptação, há testemunhas que confirmam a visita do fantasma. Além disso, em srsly Hamlet, o uso de uma fotografia, geralmente considerada como documento da realidade, não só reforça a autenticidade do fantasma (a fotografia

\footnotetext{
${ }^{68}$ Não cabe a nós puni-la. Deixe-a para os Lembre-se de mim.
} 
não tem filtros) e do espaço mágico (visão parcial de um castelo), mas também traz o raio, geralmente associado ao que é insólito e assustador.

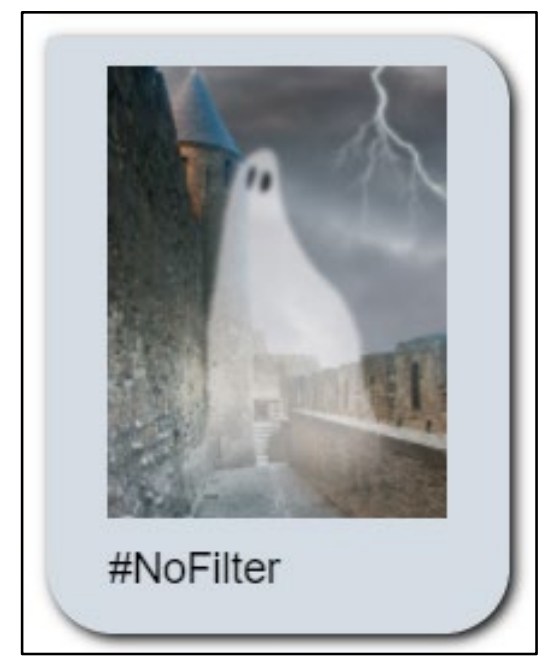

Figura 8 - O fantasma

Fonte: SHAKESPEARE; CARBONE, 2015, p. 6

É o espectro que determina a tarefa de Hamlet, ou seja, vingar seu suposto assassinato. Como visto na passagem acima, o aspecto misterioso é mais enfatizado na adaptação do que na peça. Enquanto o encontro com o fantasma ocorre perto de uma escarpa na obra shakespeariana, Hamlet e seu suposto pai fantasma entram na "Floresta Negra Horripilante" na obra de Carbone. Uma possível justificativa para essa maior ênfase pode ser a própria natureza da obra, ou seja, são ressaltadas as características que aproximam essa história dos contos infantis porque srsly Hamlet busca atrair crianças e adolescentes.

Um outro aspecto dos contos de fadas destacado por Jones costuma ser a juventude dos protagonistas, uma vez que facilita a identificação com o seu públicoalvo. Na peça de Shakespeare, embora haja controvérsias sobre a idade de Hamlet, ele é um estudante universitário capaz de mandar cartas de amor características da mocidade (II.ii). Na adaptação, embora não haja referência à universidade e as cartas sejam apenas mencionadas, ou seja, não temos acesso a seu conteúdo, certos comportamentos parecem indicar que Hamlet e seus amigos eram jovens. O próprio emoji que representa Hamlet ( $)$ mostra uma pessoa muito jovem, quase uma criança, se curvando. Um claro exemplo de comportamento juvenil pode ser observado no acréscimo feito por Carbone após o assassinato de Polônio. Ao falar 
com sua mãe, Hamlet pede ajuda e diz que está com medo de olhar o resultado de sua ação (SHAKESPEARE; CARBONE, 2015, p. 58).

Outro elemento do modelo do conto de fadas também presente no texto shakespeariano é o apoio de um amigo/servo leal. Nos dois Hamlets, Horácio é essa figura. Por ser confiável e realista, é ele quem confirma a existência do fantasma e reconhece a culpa de Cláudio quando observa a reação do rei diante da peça. Ele é a realidade que possibilita a crença na fantasia e serve, portanto, de contraponto para Hamlet e sua loucura. Apesar de querer morrer com o amigo, ele o obedece e fica para cumprir a missão determinada por Hamlet, ou seja, garantir que a verdade sobre os acontecimentos seja transmitida.

Em um primeiro momento, o narrador, um outro componente dos contos de fadas, aparenta estar ausente, isto é, parece não haver contadores de histórias na peça de Shakespeare ou no texto de Carbone. A figura tradicional do narrador realmente não é exibida, mas, ao se considerar o narrador como aquele que relata algo que ocorre fora do palco, vários personagens na peça exercem essa função. A estudiosa Marlene Soares dos Santos (2016b, p. 107) destaca que o dramaturgo inglês faz uso do recurso da narração de fatos "em maior número de vezes nesta tragédia do que em qualquer outra obra" e que, possivelmente, o personagemnarrador mais famoso da obra shakespeariana seja o fantasma do rei Hamlet. Podese dizer que o primeiro personagem a atuar como contador de histórias na peça é Horácio, quando ele explana sobre a antiga guerra entre os reis da Dinamarca e da Noruega (I.i). De certo modo, ele é o primeiro e o último narrador da história, uma vez que lhe caberá garantir que tudo o que aconteceu seja transmitido. As histórias contadas por Horácio, por Ofélia, pela rainha, pelo fantasma e pelo próprio Hamlet na peça abordam eventos passados, intensificando o texto dramático. Na adaptação, o papel de narrador de Horácio ainda é mais marcado e não se limita a eventos anteriores. Horácio é o responsável pela narração "em tempo real" do duelo entre Hamlet e Laerte. 


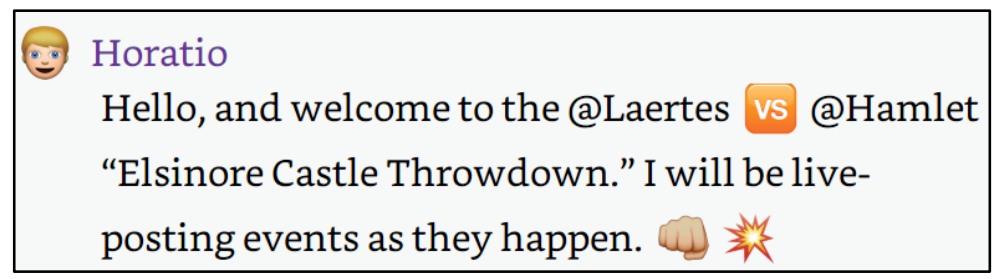

Figura 9 - Horácio como narrador 69

Fonte: SHAKESPEARE; CARBONE, 2015, p. 94

É interessante destacar que, enquanto na peça a última fala do príncipe menciona o silêncio (V.ii.342), Hamlet, na adaptação, pede para ser lembrado ("Please. Remember me. 解) ("Por favor. Lembre-se de mim. 解) (SHAKESPEARE; CARBONE, 2015, p. 100). Essa expressão remete à fala do fantasma (I.v.91) e à possível ideia de garantir, além da vingança, que sua história seja contada, que seja passada para outra geração. Tal fato reconecta o final da história com o aspecto sobrenatural de seu início. Além disso, a ideia de memória e de transmissão de experiências pode ser associada às tradições orais. Torna-se possível afirmar, então, que srsly Hamlet aproxima-se mais dos contos de fada do que a peça de Shakespeare. Uma possível justificativa para tal aproximação é a própria proposta da adaptação.

A questão do papel feminino na sociedade apresentada nos contos de fada está presente em Ofélia e Gertrudes. Tanto no texto de Shakespeare quanto nos contos de fada há uma visão patriarcal que reflete os valores da sociedade. A rainha é criticada por sua sexualidade, evidenciada pelo seu casamento apressado com o irmão do marido morto. Na peça, Hamlet destaca que a idade já deveria ter diminuído a luxúria e chega a associá-la a uma prostituta ("whored my mother") (V.ii.63). A mesma associação entre a idade e a sexualidade e a recusa em aceitar essa visão de mãe está presente na adaptação. Hamlet declara que não a queria como mãe e afirma que a rainha já é velha para ter desejo sexual: "You can’t honestly tell me you're *attracted* to him. You're now! Not and horny" ("Você não pode honestamente me dizer que se sente *atraída* por ele. Você está agora! Não é e com apetite sexual" (SHAKESPEARE; CARBONE, 2015, p. 61).

\footnotetext{
${ }^{69}$ Horácio: Olá e bem-vindos ao "Desafio no Castelo Elsinore”. A disputa é entre @Laerte e

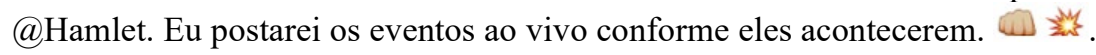


Com relação a Ofélia, o irmão, o pai e até mesmo Hamlet tentam controlar seu comportamento e sua sexualidade. Pode-se dizer, então, que a perda do pai ("He is dead and gone") (IV.v.30) e a impossibilidade do casamento com Hamlet ("You promised me to wed") (IV.v.63) impedem que Ofélia continue em seu papel tradicional (obediente e silenciosa). A partir do Ato IV, Ofélia demonstra problemas de comunicação com os demais personagens. Na peça, suas palavras tornam-se confusas e ela passa a usar músicas populares para expressar suas emoções e pensamentos. Em srsly Hamlet, Ofélia começa a postar só emojis em suas mensagens. Tal fato pode ser visto como uma forma de indicar sua loucura, mas também pode demonstrar um maior afastamento em termos de comunicação. Em Hamlet, Ofélia vai da contenção linguística dos primeiros atos para falas e canções com sentido ambíguo (IV.v). Em srsly Hamlet, a rainha não entende o que Ofélia diz e pede que ela use palavras (SHAKESPEARE; CARBONE, 2015, p. 74). Em um mundo onde o verbo tem autoridade, Ofélia não pode se expressar. No início, sua voz era controlada pelas figuras masculinas. Sua insanidade traz liberdade, mas, novamente, ela não consegue falar. Por não ter poder e não conseguir usar o código exigido na corte, ela acaba sendo destruída. Esse domínio masculino está presente até mesmo na ausência de reconhecimento da culpa na morte de Ofélia. Na peça, Laerte não reconhece seu papel no possível suicídio da irmã e não a menciona quando perdoa Hamlet por sua morte e pela do pai (V.ii.313). Na adaptação, o perdão de Laerte não menciona nomes e Hamlet diz que lamenta tanto a morte de Polônio quanto a de Ofélia, mas coloca toda a responsabilidade em Cláudio (SHAKESPEARE; CARBONE, 2015, p. 94, 99).

A ausência de um final feliz não resulta necessariamente em uma quebra do padrão tradicional. Embora as versões mais famosas dos contos de fada terminem em comemorações e/ou casamentos, tal fato pode estar associado a uma preocupação com o público jovem e não implica que seja um elemento determinante do gênero. A opção pelo fim lúgubre pode ser vista como o resultado da influência das tragédias de vingança e como um recurso empregado por Shakespeare para marcar sua obra. Santos (2016a, p. 43), ao discutir as comédias do dramaturgo, salienta que o Bardo, "na maioria das vezes, brinca com as expectativas de seus espectadores/leitores, pois ora lhes oferece um final parcialmente feliz, ora um interrogativo e, até um decididamente infeliz". Assim, é possível afirmar que a 
morte da maioria dos personagens pode também ser vista como uma forma de Shakespeare se distanciar das influências dos contos de fadas.

Merece destaque, contudo, que, como nos contos de fadas, a justiça/vingança e a harmonia são alcançadas no final da narrativa. Fortimbrás, um adequado representante da sociedade retratada na narrativa, garante a ordem (retorno a um período anterior ao da morte do Rei Hamlet) e homenageia Hamlet. Deve-se assinalar também que, na adaptação, a atmosfera nefasta do final da história é atenuada. A preocupação com o público-alvo pode ser, mais uma vez, a causa para esse abrandamento. O comentário de ficar longe da luz e a introdução da hashtag para que Cláudio não descanse em paz funcionam como elementos cômicos que diluem a violência do evento.

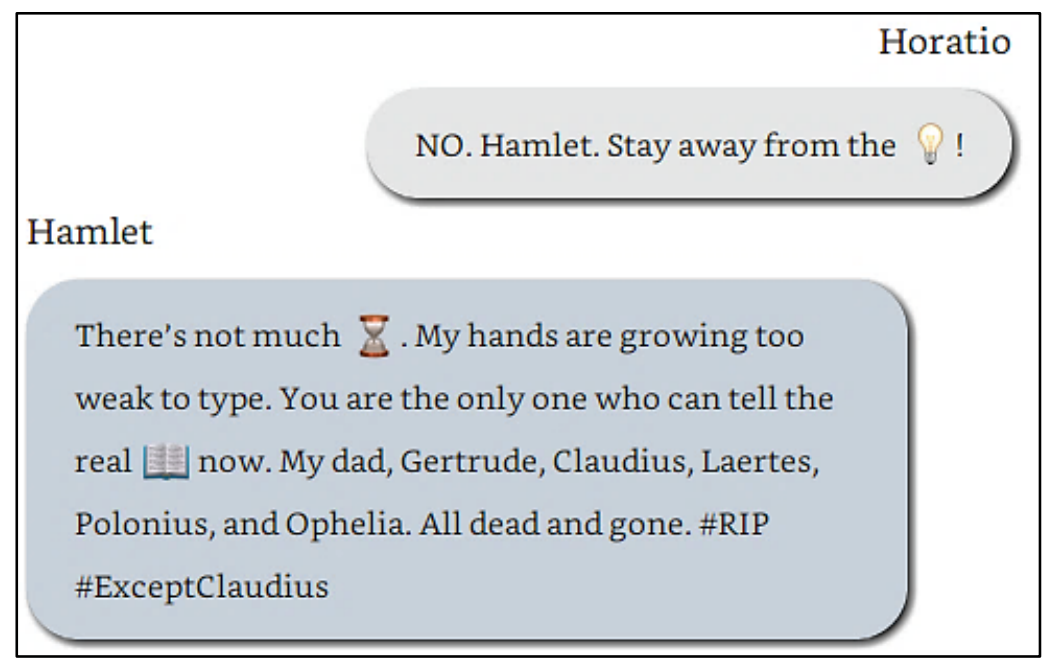

Figura 10 - Quebra da tragicidade ${ }^{70}$

Fonte: SHAKESPEARE; CARBONE, 2015, p. 99-100

É necessário frisar novamente que esta dissertação não afirma que Shakespeare fez uso dos elementos discutidos nesta seção de forma proposital. Ele pode, por exemplo, ter usado fontes que já continham tais componentes e apenas os recriou. $\mathrm{O}$ que interessa salientar é que a manutenção de temas e personagens adaptáveis (modelos arquetípicos) a sociedades de diferentes épocas e lugares pode contribuir para a natureza universal geralmente atribuída ao Bardo e a suas peças.

\footnotetext{
${ }^{70}$ Horácio: NÃO. Hamlet. Fique longe da $\bullet !$

Hamlet: Não há muito $\mathbb{Z}$. Minhas mãos estão ficando muito fracas para digitar. Você é o único que pode contar a verdadeira agora. Meu pai, Gertrudes, Cláudio, Laerte, Polônio e Ofélia. Todos estão mortos. \#Descansemempaz \#ExcetoCláudio.
} 
As inúmeras adaptações de Shakespeare que reciclam tais características parecem indicar que tais elementos são relevantes e contemporâneos. Em relação à obra de Carbone, a perpetuação desse modelo pode ser vista como um aspecto facilitador e de identificação para os leitores implícitos da adaptação. A familiaridade com o gênero e a presença de temas universais, de elementos intertextuais e da oralidade trazem o tradicional ao mesmo tempo que facilitam a inovação.

\section{3}

\section{Estrutura, tramas e subtramas}

É possível observar que tanto o texto-fonte quanto a adaptação apresentam a mesma divisão, ou seja, o Ato I traz cinco cenas, no Ato II há duas cenas, o Ato III tem quatro cenas, o Ato IV apresenta sete cenas e o Ato $\mathrm{V}$ é dividido em duas cenas. Na obra da Bloomsbury, no entanto, o número do ato com a cena é apresentado no corpo do texto e associado com instruções para entrada dos atores no palco. Em srsly Hamlet, os atos seguem a divisão tradicional e seus números são apresentados em balões de fala em páginas separadas. O número da cena aparece entre colchetes e em cor diferente do restante do corpo do texto. Talvez o destaque dado aos números de cena e de ato seja uma estratégia pedagógica para mostrar como as peças teatrais são divididas.

Considera-se importante salientar que Hamlet de Shakespeare é uma obra de natureza multimodal e intermidiática. Trata-se de um texto dramático destinado a ser encenado e que engloba, em sua realização, o gesto e a palavra, a prosa e o verso, o visual e o verbal. Ele se caracteriza pelo discurso direto e, como já indicado, não se verifica a presença de narradores no sentido tradicional. Pode-se afirmar que há dois tipos de texto na peça. O primeiro deles é o principal, isto é, trata-se do texto que apresenta os diálogos entre os personagens, os monólogos e a beleza da poesia do Bardo. O segundo tipo é a rubrica, que traz algumas poucas informações cênicas (personagens que entram na cena e local onde se passa). A obra srsly Hamlet, por outro lado, narra a história da peça e aproxima-se do gênero digital chat, uma vez que todo o texto é apresentado no formato de mensagens, o que dá um caráter mais realista à narrativa. Como na peça, o texto de Carbone é apresentado através de diálogos, indicando forte integração entre a linguagem verbal escrita e a oral. Tanto a obra de Shakespeare quanto a adaptação exibem o nome do personagem antes de 
cada fala ou mensagem. Em srsly Hamlet não há rubricas, existindo, no entanto, em algumas passagens da obra, a identificação dos personagens que participam de determinada "troca de mensagens" através da utilização da expressão "mensagens de grupo". A ideia de "entrada", ou seja, indicação de quem está na cena, só é observada quando há referências a lugares físicos específicos. Tal fato é claramente percebido no exemplo abaixo.

$\checkmark$ Hamlet and Ghost of Hamlet have checked into Creepy Black Forest.

Figura 11 - Marcação de entrada ${ }^{71}$

Fonte: SHAKESPEARE; CARBONE, 2015, p. 24

Como Hutcheon (2017, p. 6) aponta, os temas são os elementos da história mais facilmente adaptáveis não só entre mídias, mas também entre gêneros. Assim, como visto acima, é natural que todos os temas da peça shakespeariana estejam presentes na obra de Carbone. Na realidade, é possível afirmar que srsly Hamlet apresenta uma estreita relação com o texto-fonte em termos de temas, tramas e personagens. Isso está associado ao próprio objetivo da série, isto é, servir como uma espécie de introdução para a peça de Shakespeare.

Quando discuti as possíveis influências na peça de Shakespeare em 3.2, mencionei alguns dos temas presentes na peça: vingança, lealdade, loucura, corrupção (sexual e política), contraste entre aparência e realidade, dúvida, legitimidade e mortalidade/suicídio. Também destaquei que a trama principal gira em torno da vingança de Hamlet contra o tio, responsável pela morte do pai. Entre as tramas secundárias, destacam-se a da vingança de Laerte (pela morte do pai e da irmã) e a de Fortimbrás (pela morte do pai e perda de terras). Pode-se dizer que as relações familiares desses dois personagens e suas ações em busca de vingança funcionam como contraponto para a atitude de Hamlet para com os pais e o tio. Outros enredos secundários presentes na peça são o relacionamento entre Hamlet $\mathrm{e}$ Ofélia, a peça dentro da peça e a relação de Rosencrantz and Guildenstern com o poder e com Hamlet.

${ }^{71}$ Hamlet e o Fantasma de Hamlet entram na Floresta Negra Assustadora. 
Este estudo não busca analisar as possíveis leituras dos temas e enredos da peça, mas apenas salientar que todos são, de algum modo, encontrados na adaptação. As alterações observadas podem ser, em geral, justificadas pela necessidade de redução do tamanho do texto (condensação de eventos e cortes no número de falas), pela tentativa de facilitar a leitura e pela preocupação em lidar com temas tidos como tabus ou preconceituosos na literatura voltada para jovens. Na passagem abaixo, por exemplo, quase todos os temas abordados no solilóquio da peça são mantidos. Há a condenação religiosa ao suicídio, mas a menção à frivolidade das mulheres é eliminada. A referência à morte, o humor melancólico de Hamlet e as críticas ao tio e à mãe são amenizados pelo uso dos emojis. O uso de "kind of" ("meio que") e "Just saying" ("Só um toque") reduz o efeito da acusação de incesto.

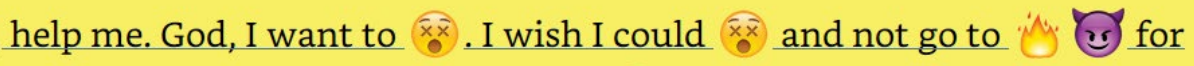
killing myself. My dad hasn't even been 장 two months, and already everyone has forgotten about him. He was such an amazing ty, and he gets replaced by my 흥 uncle.

Does no one remember how good my father was to my mother? I wish I didn't have to about it. She was $\oslash \circlearrowright \oslash$ with him. And yet 217 s later she has completely moved on. How is that possible?? Even of : . : are more loyal than that. And not only does she move on, she MARRIES $\$$ my father's brother. My UNCLE. Who is the complete and total OPPOSITE of my father. Her $D_{0}$ were barely dry by the wedding. It's too much too fast. (Also, kind of INCEST. Just saying.)

It's bad. And I know it will only get worse. And yet... $९$ as I am, there's nothing I can do.

Figura 12 - Temas e tramas suavizados ${ }^{72}$

Fonte: SHAKESPEARE; CARBONE, 2015, p. 12-13

72 me ajude. Deus, eu quero . Gostaria de e não ir para o 중 por me matar. Meu pai não está nem há dois meses, e todos já o esqueceram. Ele era um incrível e foi substituído pelo

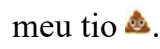

Ninguém se lembra como meu pai era bom para minha mãe? sobre isso. Ela era $\bullet \bullet \bullet$ com ele. Ainda assim $2 \frac{17 \mathrm{ts}}{17 \mathrm{~s}}$ depois ela seguiu em frente totalmente. Como isso é possível? Até os 1.0 são mais leais. Ela não apenas seguiu com a vida, ela SE CASOU 8 com o irmão do meu pai. MEU TIO. Ele é o total oposto do meu pai. Suas $08^{\circ} \mathrm{mal}$ tinham secado na época do casamento. Foi tudo muito rápido. (Também é meio que incestuoso. Só um toque.)

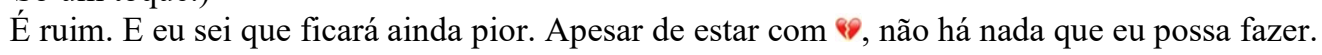


A única mudança no enredo que parece não ter como justificativa questões pedagógicas ou normas literárias refere-se a Rosencrantz e Guildenstern. Em primeiro lugar, é interessante destacar que Carbone (2015) usa um único emoji para identificar os dois personagens (鲕). Tal fato parece reforçar o caráter complementar dos dois amigos, que acabam formando uma única entidade. É possível afirmar, uma vez que suas personalidades são pouco definidas, que eles apenas atuam como instrumentos da narrativa. $\mathrm{Na}$ adaptação, esse aspecto superficial e ambíguo da dupla foi mantido. Ainda paira a dúvida, por exemplo, se eles tinham consciência do plano do rei contra Hamlet ou se eram, como Hamlet afirma, apenas "esponjas" que sugavam as recompensas oferecidas pelo rei (IV.ii.11-19). Contudo, Carbone parece permitir uma maior participação dos personagens em seu destino. São eles que se oferecem para falar com Hamlet (SHAKESPEARE; CARBONE, 2015, p. 33), e é Rosencrantz que diz que eles irão com Hamlet para a Inglaterra e que percebe que Hamlet “[...]'s just playing games.

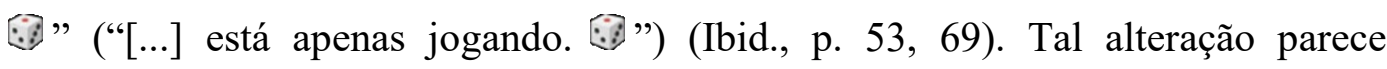
demonstrar uma menor subserviência dos personagens. A própria interação deles com a realeza é apresentada com menos adulação. Rosencrantz faz um comentário mordaz sobre a rainha para Hamlet quando fala "I'll tell $\mathrm{u}$ what ur mother luvs. " (“Eu direi o que sua mãe ama. (S)") (SHAKESPEARE;CARBONE, 2015, p. 48). Na peça, é improvável que ele fizesse tal comentário sobre alguém da nobreza.

\section{4 Personagens, espaço e tempo}

Quando abordo os personagens presentes na peça shakespeariana e em srsly Hamlet, não tenho como objetivo discutir as múltiplas facetas dessas criações tão complexas e sutis. Muito já foi falado e muito ainda falta para analisar a riqueza de personagens que se constroem em sua relação com os outros e com o público. $\mathrm{O}$ propósito deste estudo é identificar as possíveis alterações na caracterização dos personagens feitas no processo de adaptação e como tais mudanças em relação ao texto-fonte podem estar relacionadas à transposição para a literatura infantil e juvenil. 
De acordo com Thompson e Taylor, o Segundo Quarto tem 31 papéis com falas (2016, p. 588). Ao contrário dos personagens de Hamlet da série The Arden Shakespeare, que são introduzidos através de uma lista com os nomes ou funções, acompanhados, em geral, por uma breve descrição de seu papel na história, srsly Hamlet traz os nomes e papéis de apenas 19 personagens em uma página com um título informal ("Quem é quem”). Além disso, essa página da adaptação apresenta os emojis associados a cada um deles. É interessante destacar que tal identificação visual não gera individualização, ou seja, a associação é feita apenas por características gerais (gênero ou idade). Muitos deles são caracterizados apenas por parte do vestuário a eles conectados.

A obra de Carbone apresenta uma segunda lista com os personagens que foram cortados ou apenas mencionados. O Capitão de Fortimbrás, por exemplo, nunca aparece. Cabe a Hamlet descrever sua conversa com ele e garantir, assim, a progressão da ação. Embora esses personagens secundários desempenhem funções importantes na peça shakespeariana, ou seja, as de trazer informações sobre fatos que não ocorrem no palco, de intensificar os temas, de trazer alívio cômico e de ajudar na revelação da personalidade de Hamlet, a opção por sua retirada pode estar relacionada às expectativas em termos das habilidades de leitura de crianças e adolescentes e do que caracteriza a literatura infantil e juvenil.

Antes de analisar essas e outras possíveis justificativas para os cortes de certos personagens, é interessante destacar o uso do emoji "telefone analógico" ao lado dos personagens que não aparecem. Tal fato pode ser uma forma de destacar o mundo digital no qual o enredo está inserido e de trazer para dentro da história a justificativa dessa ausência, isto é, eles não participam da história (ou da conversa) porque não possuem telefones adequados.

Como exemplo de redução de texto em srsly Hamlet para atender as expectativas do sistema literário e das políticas educativas (capacidade de leitura e de compreensão dos leitores implícitos), pode-se citar a ausência dos atores que encenam $O$ Assassinato de Gonzago e, por conseguinte, da passagem que apresenta a encenação. Hamlet descreve o que acontece na peça para os demais personagens, e a explicação para tal é a dificuldade dos personagens, excluindo-se Cláudio, que parecem não entender o que se passa. Trata-se de um recurso (cenas não encenadas) que, como já foi discutido anteriormente, o próprio Shakespeare usa para relatar a 
guerra entre os pais de Hamlet e de Fortimbrás, para contar como o antigo rei foi assassinado e para revelar a morte de Ofélia e a troca do conteúdo da carta para o rei da Inglaterra. A única diferença é que, na passagem abaixo, Hamlet narra um momento presente e não um que ocorreu no passado.

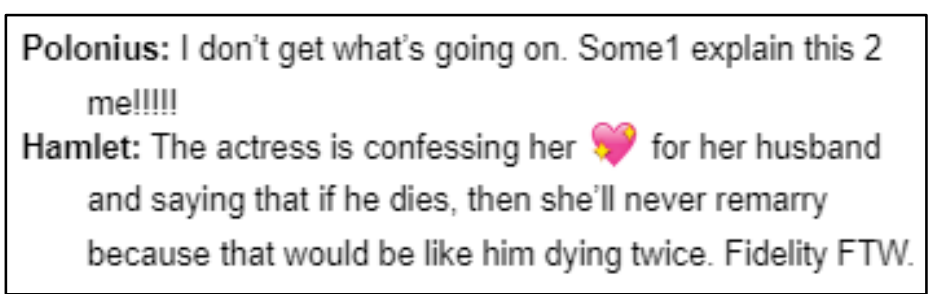

Figura 13 - Explicação da peça dentro da peça ${ }^{73}$ Fonte: SHAKESPEARE; CARBONE, 2015, p. 48

A ausência do sacerdote no enterro de Ofélia, por outro lado, pode estar associada a uma tentativa de reduzir as menções a instituições religiosas (busca por um texto adequado e útil para os leitores). As únicas referências presentes são ao céu, ao inferno e à igreja, mas trata-se de generalizações e, na maioria das vezes, aparecem através de emojis.

Um corte importante na adaptação é o do cortesão Osric. Tal fato pode estar conectado à necessidade de se reduzir o tamanho do texto. Contudo, também é possível que seja uma estratégia de simplificação. Hamlet e o cortesão usam um linguajar tão elaborado que Horácio, na peça, destaca a dificuldade de compreensão ("Is’t not possible to understand in another tongue?") ("Não é possível vocês se fazerem entender em outra língua?”) (V.ii.110)). Além disso, Osric, um tolo rico e bajulador, é humilhado por Hamlet na cena em que traz o convite do rei para o duelo com Laerte. Courtney, talvez, tenha retirado a passagem por não ser possível transmitir a mesma comicidade que a cena tinha na época e por tentar não apresentar um Hamlet que possa ser considerado, nos dias atuais, cruel ou esnobe. É interessante destacar, no entanto, que as demais funções narrativas de Osric na cena foram mantidas em outra cena da adaptação. Observa-se, na passagem abaixo, a informação sobre a aposta no duelo, a desconfiança de Horácio, a imprudência de Hamlet e o jogo de palavras. A dificuldade na compreensão das palavras presente

\footnotetext{
${ }^{73}$ Polônio: Eu não entendo o que está acontecendo. Algm me explique!!!!!

Hamlet: A atriz está confessando seu por seu marido e dizendo que, se ele morrer, ela nunca casará novamente porque seria como se ele morresse duas vezes. Fidelidade é a melhor.
} 
no diálogo entre Osric e Hamlet parece ser reproduzida através do uso de "\#SWAG". Ao contrário das falas de Osric, que transmitem uma ideia de ausência de significado, de superficialidade, swag caracteriza-se pela riqueza de sentidos que foram sendo associados desde o século XVII, o que também pode gerar problemas de interpretação. Entre outras coisas, essa palavra pode significar guirlanda (século XVIII), material roubado (século XIX) (HOAD, 1996, p. 475) e brinde promocional ("Stuff We All Get"). Todos os sentidos são possíveis na cena. O primeiro e o último sentidos parecem se referir apenas ao prêmio, enquanto o segundo ("material roubado") acrescenta uma outra camada semântica, ou seja, pode aludir à ideia de que o reino da Dinamarca foi roubado por Cláudio, mas pode ser recuperado no duelo. Um outro fator interessante é o uso que Laerte faz da gíria "bro" ao conversar com Hamlet. O emprego do termo "amigo" pode ser visto como uma forma de enganar o príncipe ou uma ironia, isto é, suas palavras têm o sentido oposto de suas intenções. Contudo, pode ser uma estratégia de Carbone para destacar que Hamlet e Laerte são dois lados da mesma moeda, ou seja, embora inimigos, compartilham certas características que permitem que sejam incluídos no que é conhecido como "cultura bro". O termo é geralmente associado a homens brancos de classes privilegiadas pertencentes a fraternidades, grupos esportivos e certas organizações profissionais que adotam uma postura machista e que excluem a diferença. O diálogo de Hamlet com Osric reforça o fato de que Hamlet e Laerte fazem parte do mesmo grupo social e cultural, e destaca o aspecto competitivo entre os dois personagens (presente também na cena do enterro de Ofélia). A participação dos dois personagens no duelo e a relação controladora que têm com Ofélia podem ser vistas como exemplos dessa participação na "cultura bro". 


\section{Claudius}

@Hamlet @Laertes: I challenge u 2 a duel! Place your bets, ladies \& gentlemen.

Winner gets \#SWAG \#SWAG \#SWAG \#SWAG

1

Laertes: Come @ me bro

Hamlet: *shrug* Why not?

Horatio: You guys sure this is a good idea?

Figura $14-\mathrm{A}$ ausência de Osric ${ }^{74}$

Fonte: SHAKESPEARE; CARBONE, 2015, p. 93

Com relação aos personagens encontrados na adaptação, é possível afirmar que Carbone manteve suas características básicas. As alterações observadas estão, em grande parte, relacionadas a normas do sistema literário e à tentativa de aproximar o texto à realidade dos jovens contemporâneos. Este estudo analisa três personagens presentes na adaptação, uma vez que eles claramente exemplificam as alterações sofridas em relação à peça. Hamlet, tanto na peça quanto em srsly Hamlet, é apresentado como um ser melancólico, desapontado com o mundo, irônico e inteligente. Ao contrário de Laerte e Fortimbrás, o príncipe, apesar da natureza passional, é um homem de palavras. Sua agressão, na maioria das vezes, é verbal. Suas ações físicas geralmente ocorrem em decorrência de fatores externos, não são iniciadas por ele. Contudo, através do uso dos emojis, que, como já foi visto, são recursos de realce de sentido através da ênfase na cordialidade do tom ou da inserção de matizes de humor (DANESI, 2017, p. 15), e de certos comentários, os traços de sua personalidade que poderiam ser considerados negativos (violência física e verbal, orgulho e ciúme) são atenuados. Na passagem abaixo, após acusar a mãe de traição e falar sobre o assassinato do pai, Hamlet demonstra certa ironia ao falar sobre Rosencrantz e Guildenstern e sua ida para a Inglaterra. O uso dúbio do termo "bons amigos" indica a perspicácia do príncipe em relação à intenção do rei, mas não há, como na peça, a agressividade, por exemplo, de comparar Rosencrantz e Guildenstern a víboras e de considerar o esforço para suplantá-los como uma guerra. A frieza em relação à morte de Polônio também é atenuada com

\footnotetext{
74 Cláudio: @Hamlet@Laerte: Eu os desafio para um duelo! Façam suas apostas, senhoras \& senhores. O vencedor leva \#LAUREL\#LAUREL\#LAUREL\#LAUREL

Laerte: Venha até aqui mano

Hamlet: *dando de ombros* Por que não?

Horácio: Rapazes, vocês têm certeza de que é uma boa ideia?
} 
a menção do cartão de crédito e com o uso do emoji "careta". Tal pictograma é geralmente empregado para indicar constrangimento, nervosismo ou quando ocorreu um erro. Na lista de sentidos apresentada no final da adaptação, esse pictograma está associado a embaraço.

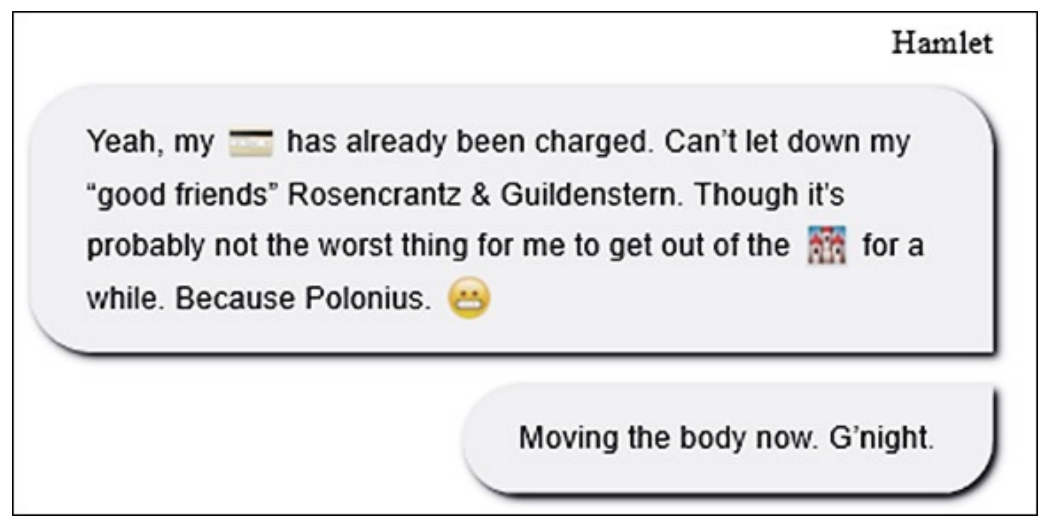

Figura 15 - Hamlet mais suave na adaptação ${ }^{75}$ Fonte: SHAKESPEARE; CARBONE, 2015, p. 64

Um fato curioso que merece ser apontado é que, embora seja mencionada a tristeza de Hamlet pela morte do pai, sua raiva, mesmo antes de encontrar o fantasma, é mais enfatizada na adaptação. Logo no início da peça o príncipe afirma “Seem? No, Mother. I don’t SEEM @. I AM ‥" (“Parecer? Não, Mãe. Eu não PAREÇO •. EU ESTOU •.") (SHAKESPEARE; CARBONE, 2015, p. 11). Tal postura parece aproximá-lo da natureza de Laerte e de Fortimbrás, cujas ações são guiadas pela raiva. Cabe também ressaltar que uma definição para loucura é "raiva extrema". Assim, o emoji também pode ser considerado um indício da futura insanidade associada ao príncipe.

Assim como Shakespeare, Carbone apresenta Cláudio como um governante inteligente, hábil com as palavras, ambicioso e carinhoso com a esposa. O personagem, nas duas obras, reconhece seu crime e sua condenação, mas sabe que não agiria de forma diferente porque não consegue abrir mão do que conseguiu (“\#SorryNotSorry”) (\#LamentoNãoLamento”) (SHAKESPEARE; CARBONE, 2015, p. 54). Contudo, assim como no caso de Hamlet, as ações mais cruéis do rei

\footnotetext{
${ }^{75}$ Hamlet: Sim, o valor já foi cobrado no meu - Não posso desapontar meus "bons amigos" Rosencrantz \& Guildenstern. Embora não seja tão ruim para mim sair do causa de Polônio. : Movendo o corpo agora. Boa noite.
} 
são diluídas. O fato de o solilóquio de Cláudio em que ele revela seus planos para matar Hamlet (IV.iii.56-66) ser transformado em uma mensagem de texto com uma lista do que deve ser feito, por exemplo, já quebra a gravidade de seu conteúdo. Além disso, a menção ao esquema para assassinar Hamlet vir acompanhada da ideia de postar selfies acrescenta ainda mais ludicidade para a passagem. A ironia no final do texto traz uma quebra de expectativa e gera o riso.

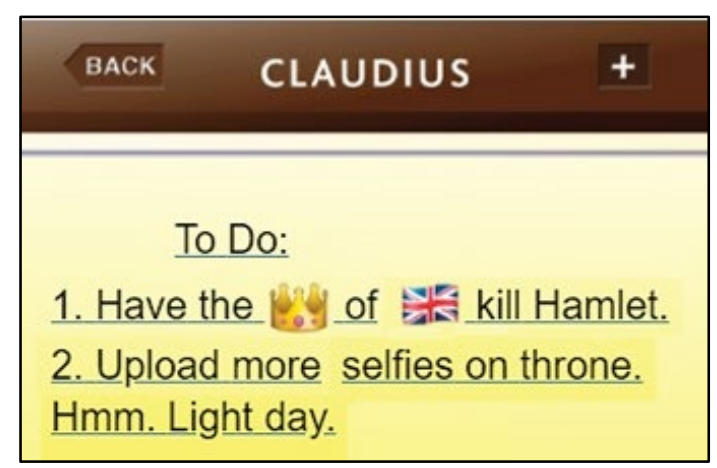

Figura 16 - Diluição dos aspectos sombrios ${ }^{76}$ Fonte: SHAKESPEARE; CARBONE, 2015, p. 72

É interessante destacar também a natureza de Ofélia na adaptação. Shakespeare e Carbone a apresentam como uma filha leal, uma jovem bonita, inocente e apaixonada por Hamlet, que provavelmente fica louca não só por perder o seu amor, mas também por ter seu pai assassinado por ele. Ao contrário da peça, no entanto, a única conotação sexual associada a ela é feita por Polônio, quando a acusa de estar trocando carícias com Hamlet (SHAKESPEARE; CARBONE, 2015, p. 20). Ofélia parece ter também, em srsly Hamlet, uma maior capacidade para se impor. Ela grita com o pai para enfatizar que só fez o que ele tinha mandado e grita com Hamlet exigindo uma resposta sobre a devolução das cartas de amor e o fim do relacionamento. Uma outra diferença em relação ao texto-fonte diz respeito a uma atitude mais brincalhona e, algumas vezes, sarcástica de Ofélia. Tal característica pode ser observada quando, após os comentários de Hamlet a respeito da falsidade das mulheres e da crueldade dos homens, Ofélia posta de forma irônica: "wow. tell me how you really feel" ("uau. não esconda seus sentimentos)

\footnotetext{
${ }^{76}$ Coisas a fazer:

1. Fazer o $\mathrm{x}$ da

2. Fazer o upload de mais selfies no trono. Hmm. Dia tranquilo.
} 
(SHAKESPEARE; CARBONE, 2015, p. 45). Um outro exemplo pode ser percebido na relação entre Laerte e Ofélia. Na peça, há um carinho e um respeito entre eles, mas não há as gozações comuns entre irmãos. Na cena abaixo, a brincadeira com o uso de $2 s$ para representar a preposição to e o fato de chamar o irmão de tolo retratam uma Ofélia mais descontraída, jovial e contemporânea.

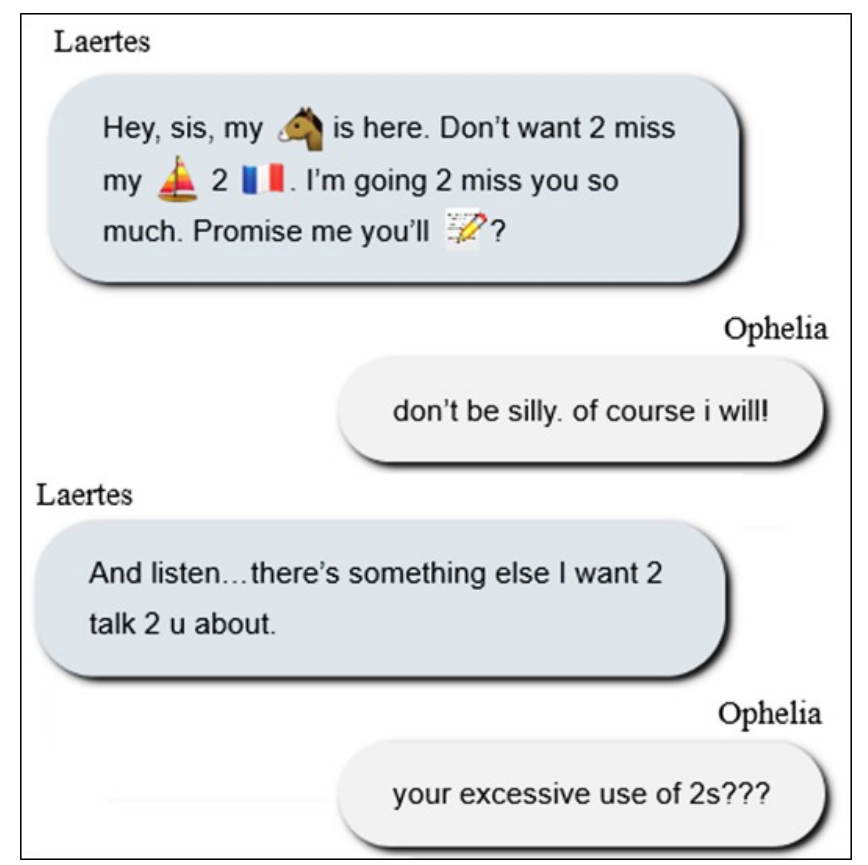

Figura 17 - A descontração de Ofélia ${ }^{77}$

Fonte: SHAKESPEARE; CARBONE, 2015, p. 16-17

Com relação aos demais personagens, pode-se dizer basicamente a mesma coisa, ou seja, eles são apresentados de forma mais despojada, e aquilo que pode ser considerado como inadequado ou negativo em suas ações é suavizado. É possível afirmar que, ao mesmo tempo em que há ainda um certo controle sobre o conteúdo do texto adaptado, busca-se retratar os personagens, principalmente os considerados jovens, dentro de uma visão mais atual.

Ao se considerar a encenação de Hamlet, é possível identificar os três níveis de modalidade espacial (ELLESTRÖM, 2010b, p. 20), ou seja, essa obra caracteriza-se pela modalidade espacial física, pela cognitiva (sempre presente em

\footnotetext{
${ }^{77}$ Laerte: Ei, mana, meu está aqui. Não quero perder meu saudades suas. Promete que irá $@$ ?

Ofélia: não seja tolo. Claro que irei!

Laerte: Escute...tem outra coisa que quero falar c/ vc.

Ofélia: seu uso excessivo de infinitivos???
} 
todas as mídias) e pela virtual. O espaço físico da peça pode ser dividido em duas categorias. O espaço teatral é composto pelo palco, dependências laterais e acomodações para o público. O espaço cênico, por sua vez, traz, através de convenções e parcos recursos visuais, os locais onde a história se passa (interior do castelo Elsinore, plataforma externa do castelo, casa de Polônio, planície e cemitério). Enquanto o espaço físico (teatral e cênico) permite o engajamento perceptual da audiência, a construção do espaço abstrato (aspecto interpretativo) deve-se às características do próprio teatro shakespeariano. Como a professora, tradutora e crítica de teatro Barbara Heliodora (2008, p. 72) destaca, "[n]o palco elisabetano, iluminado pela luz do dia e sem cenários, [...] tudo era possível, desde que o diálogo atingisse a imaginação do espectador”. A obra de Carbone, como já apontado no segundo capítulo desta dissertação, possui, em princípio, as mesmas dimensões do texto impresso da série da editora Bloomsbury (espaço material bidimensional). Contudo, sua camada virtual não é apenas abstrata, mas criada a partir da percepção sensorial. Na foto abaixo, por exemplo, o contraste entre claro e escuro parece aumentar a sensação de volume e profundidade percebida pelo leitor, gerando o espaço virtual.

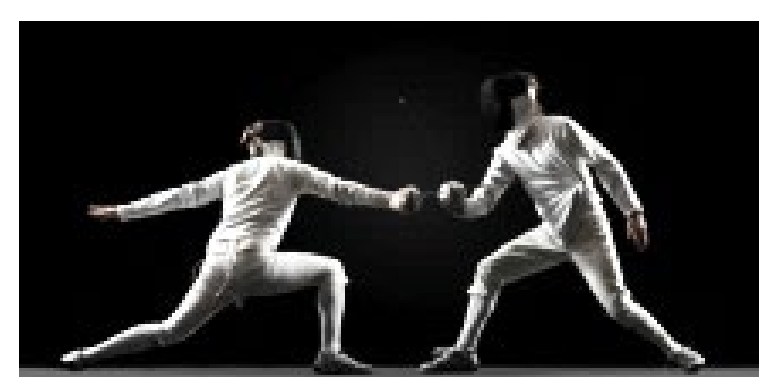

Figura 18 - Espaço virtual Fonte: SHAKESPEARE; CARBONE, 2015, p. 95

É interessante também destacar que, embora os emojis mantenham sua natureza bidimensional, eles, em algumas passagens da adaptação, parecem funcionar como acessórios cenográficos (poucos itens formavam o cenário elisabetano) e/ou podem trazer uma noção de perspectiva. Na passagem abaixo, a maioria dos emojis desempenha função semelhante à das imagens produzidas pelo texto shakespeariano, ou seja, contribuem para a construção do local onde Ofélia morreu. Na adaptação, contudo, o espaço deixa de ser apenas conceitual. 


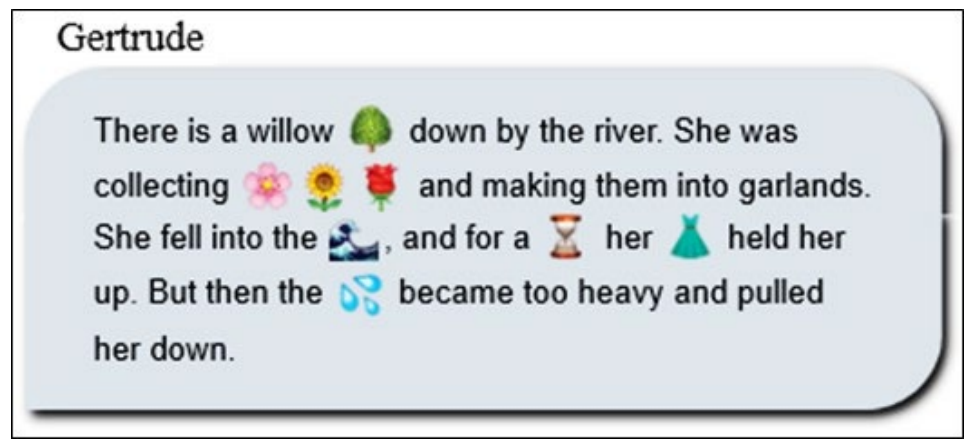

Figura 19 - Possíveis elementos cênicos ${ }^{78}$

Fonte: SHAKESPEARE; CARBONE, 2015, p. 86

Além disso, como já visto na fundamentação teórica desta dissertação, a própria imitação de uma plataforma digital para troca de mensagens já cria um espaço que onde não só os personagens interagem (uma espécie de palco virtual), mas onde também os leitores têm a ilusão de estar imersos. A partir da análise de todos esses fatos, é possível afirmar que, na adaptação, são encontradas estratégias que procuram aproximar a obra da mídia teatro, ou seja, alguns elementos que caracterizam o teatro de Shakespeare são revisitados em srsly Hamlet.

Marlene Soares dos Santos (2008, p. 195) destaca que Shakespeare criou uma nova concepção de tragédia ao, entre outras coisas, adaptar "a influência clássica a seu modo - dispensando as unidades de ação, lugar e tempo". Em Hamlet, onde tudo reside na imaginação, "The time is out of joint"79 (I.v.186), isto é, não há indicações claras da passagem do tempo cronológico. A lacuna de tempo entre as cenas varia desde uma sequência imediata até a impressão da passagem de meses, há informações contraditórias e ausência de marcações claras nos diálogos ou nas indicações cênicas. Parece importante destacar, no entanto, a estratégia presente na adaptação para garantir que tal indeterminação seja mantida. Ao escolher reproduzir o aplicativo de mensagens em seu texto, Carbone garante não só a presença de todos no mesmo espaço, mas traz a experiência de tempo presente (conversa em tempo real). A adaptação também sustenta a manutenção do tempo linguístico e a imprecisão temporal presente na peça. Através da eliminação dos marcadores temporais (timestamps), comuns nas mensagens de WhatsApp, a passagem do

\footnotetext{
${ }^{78}$ Getrudes: Existe um salgueiro $\odot$ na beira do rio. Ela estava colhendo 8 \&

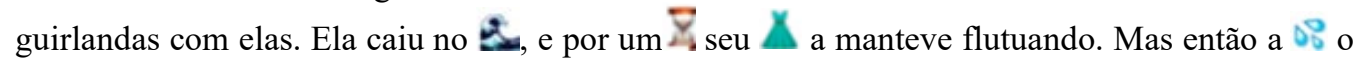
fez ficar pesado e puxou Ofélia para o fundo.

79 "O tempo está desarticulado".
} 
tempo só é indicada no corpo do texto verbal. Parece, então, que srsly Hamlet manteve todas as dimensões espaciais (teatral/cênica, cognitiva e virtual) e temporais (da interação com a própria mídia, perceptual e virtual) através do uso da linguagem verbal e de recursos visuais.

O emprego de estratégias para a criação da ilusão de profundidade e de movimento possibilitaram que características e convenções da peça fossem recriadas no texto escrito da adaptação. Apesar de o espaço físico da obra ser, na realidade, uma página plana, na passagem abaixo tem-se o entendimento de um espaço cênico (sala no castelo) e de um espaço teatral (gerado pela ilusão de participação em uma plataforma digital de mensagens). Atores e público, nesse caso, compartilham o mesmo espaço virtual, e os espaços da obra são gerados pelos atos interpretativos e perceptivos. A sequencialidade temporal da peça também está incorporada no exemplo abaixo. Embora os emojis (pessoa correndo, colisão e punho) sejam estáticos, sua repetição transmite uma ideia de movimento (luta) e, por conseguinte, de passagem de tempo (virtual).

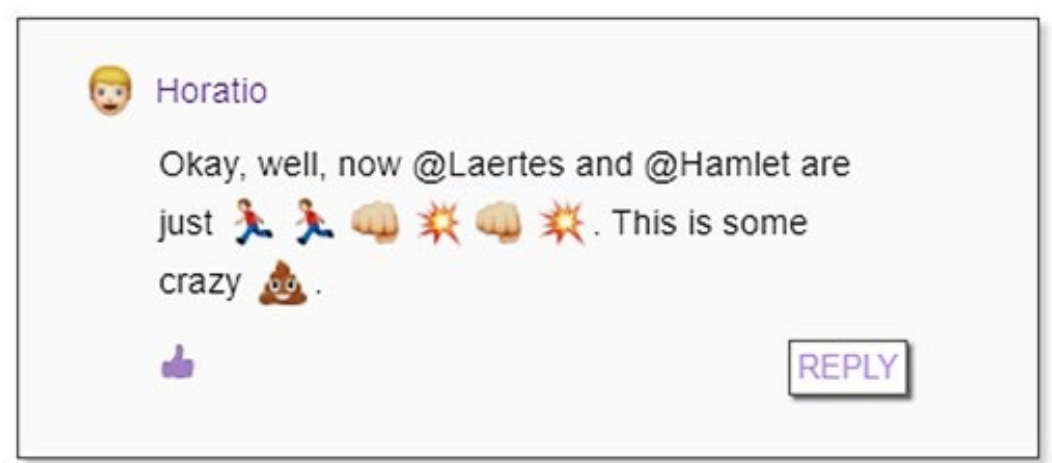

Figura 20 - Espaços e tempos ${ }^{80}$

Fonte: SHAKESPEARE; CARBONE, 2015, p. 96

\section{5}

\section{Confluência de linguagens}

Ao trazer Shakespeare para o sistema literário infantil e juvenil por conta de seu capital cultural, a disputa entre manter o interesse dos leitores e preservar a função formativa fica mais acentuada. A professora Erica Hateley destaca a oposição entre a capacidade de entretenimento de Shakespeare, relacionada aos

\footnotetext{
${ }^{80}$ Horácio: OK, bem, agora@Laerte e @Hamlet só estão $\lambda$ 文
} 
enredos das peças, e o valor educacional, conectado à linguagem, e como é difícil comunicar os dois. Hateley acrescenta que

os autores atuais aparentemente consideram a linguagem das peças de Shakespeare valiosa, mas difícil, e concordam em introduzir para os leitores jovens os enredos de Shakespeare, interpelando as crianças como futuros leitores das peças de Shakespeare. ${ }^{81}(2009$, p. 3)

Pode-se dizer que a força de Hamlet reside nas palavras, elas não são apenas o meio de comunicação da peça. É através delas que os personagens se constroem e lidam com o mundo. O poder das palavras as torna uma forma de vida capaz de criar e de destruir na Dinamarca hamletiana. Courtney Carbone, como já foi exposto, manteve os enredos e temas da peça shakespeariana em sua adaptação. A autora, no entanto, parece ter seguido a tendência de não fazer uso do que geralmente é chamado de linguagem shakespeariana. Por exemplo, todas as alusões a outras obras e personagens clássicos são eliminadas. Tal fato parece ser o resultado da preocupação em não dificultar a leitura para certas faixas etárias ao trazer referências que não sejam familiares. Em outras palavras, esse corte reflete a crença de que certos conhecimentos culturais não são acessíveis para determinadas faixas etárias de leitores e, portanto, torna-se muito difícil para tais grupos fazer as conexões entre as citações e o assunto abordado. A únicas alusões claras que foram mantidas em srsly Hamlet são a de Caim e Abel (SHAKESPEARE; CARBONE, 2015, p. 54) e a serpente do Jardim do Éden (Ibid., p. 25). Uma possível justificativa para sua manutenção pode ser a proximidade em termos culturais. Com relação à serpente no paraíso, mesmo que a referência não seja percebida, ainda é possível fazer a conexão entre o animal e o veneno que matou o pai de Hamlet. Na maioria das passagens, optou-se por manter apenas a ideia que a citação transmite. Um exemplo dessa estratégia pode ser observado abaixo. Embora a menção a Nero (III.ii.384) tenha sido retirada, a ideia de não agir como ele, ou seja, de não matar sua mãe, só a atacar verbalmente, é apresentada.

\footnotetext{
81 "Today authors seemingly consider the language of Shakespeare's plays valuable but difficult, and settle instead for introducing juvenile readers to Shakespeare's plots, interpellating children as future readers of Shakespeare's plays."
} 


\section{I will ' her... metaphorically... with my words. (Didn't mean for that to sound awkward.)}

Figura 21 - Eliminação da alusão ${ }^{82}$

Fonte: SHAKESPEARE; CARBONE, 2015, p. 52

Enquanto na peça shakespeariana há a junção entre poesia e prosa (uso de versos brancos e rimas associados à linguagem do dia a dia), as mensagens em srsly Hamlet são todas em prosa. Essa remoção da estrutura poética na adaptação é importante porque, como Martins (1999, p. 141) destaca, "a opção pela combinação verso/prosa, conforme usada pelo poeta, ou simplesmente pela prosa, terá influência crucial na percepção de Shakespeare por parte dos leitores". Segundo Martins, o verso tem, no drama shakespeariano, uma série de funções, como: exteriorizar paixões ou fortes emoções, expor conspirações ou intrigas, indicar ambiguidade ou reticência e expressar ideias de forma mais clara e precisa. Com relação à rima, embora não seja muito empregada no Hamlet inglês, ela pode indicar, por exemplo, o término de cenas e a importância dada a certas falas pelo dramaturgo (MARTINS, 1999, p. 141-142). A escolha pela prosa na adaptação parece, em um primeiro momento, gerar uma perda no processo de construção de significados. Na realidade, pode-se afirmar que tal decisão não elimina o potencial de sentidos da linguagem da peça, uma vez que Carbone faz uma releitura dos elementos que os constroem, trazendo-os para o contexto dos leitores jovens contemporâneos e permitindo que a significação do texto escrito, assim como ocorre na peça, seja (re)construída nessa interação.

A estudiosa sueca Inga-Stina Ewbank (1986) destaca que os personagens em Hamlet estão conscientes do poder das palavras e reconhecem a necessidade de traduzir verbalmente suas intenções e experiências. Traduzir, segundo Ewbank, significa, nesse caso, interpretar, mudar e estar consciente das palavras empregadas no processo. Em um dos exemplos apresentados, a professora cita o pedido de Cláudio a Gertrudes para que ela traduza os sinais de sua angústia, ou seja, ele quer que ela traduza uma linguagem visual para uma verbal. Pode-se dizer que Courtney

\footnotetext{
${ }^{82}$ Eu irei -la...metaforicamente...com minhas palavras. (Não era minha intenção que isso soasse esquisito.).
} 
Carbone fez a tradução, vista como interpretação e mudança, no sentido reverso, ou seja, do verbal oral para o visual.

Uma possível justificativa é o próprio gênero textual da adaptação, ou seja, o chat caracteriza-se pelo uso da prosa informal. É claro que tal escolha acarreta a ausência de certos elementos formais da poesia como, por exemplo a estrutura métrica (pentâmetro iâmbico), a rima, a aliteração e a assonância, na construção dos sentidos. Contudo, tendo por base a teoria das funções da linguagem do linguista Roman Jakobson (1960, p. 356), é possível afirmar que a função poética da linguagem continua a ser dominante, ou seja, a ênfase recai na forma da mensagem, onde os diferentes tipos de signos são explorados para a produção dos sentidos.

Ao analisar a função dos emojis, Marcel Danesi (2017) destaca que há um predomínio das funções emotiva (expressão de sentimentos e emoções) e fática. A função fática apresentada pelo professor, no entanto, apresenta diferenças em relação à teoria de Jakobson. Para Danesi, essa função implica a manutenção de um tom amigável e alegre na comunicação e não envolve necessariamente o papel de atrair a atenção do interlocutor, estabelecer, prolongar ou terminar uma comunicação (JAKOBSON, 1960, p. 355). Contudo, essas duas funções dos pictogramas no texto adaptado ocorrem na troca de mensagens entre os personagens, não com o leitor. A interpretação dessas funções pelo leitor, no entanto, pode contribuir para a imagem de Hamlet que para ele será formada. Danesi também salienta que o sistema semântico dos emojis tem nuances conotativas intrínsecas e, até um certo grau, poéticas. Ao escrever para Hamlet "If you ever really ed me [...]" ("Se você realmente me [...]") (SHAKESPEARE; CARBONE, 2015, p. 25), o fantasma faz uso de um coração azul para falar dos sentimentos do filho. Usado nesse contexto, esse signo visual traz valores conotativos associados a aspectos culturais. $\mathrm{O}$ simbolismo do coração (amor/amar) é um exemplo da função poética da comunicação. Além disso, a cor azul associada ao coração geralmente indica amizade e/ou lealdade e introduz um novo nível de significado à mensagem, ou seja, o fantasma não só questiona o amor do filho, mas também sua lealdade.

O discurso poético se caracteriza pelo rico uso de figuras da linguagem. Já foi mencionado acima que algumas dessas figuras presentes na peça não foram transpostas para a adaptação, uma vez que o gênero chat não propicia tal emprego. 
Contudo, outras sofreram uma releitura. Um exemplo pode ser encontrado na fala de Cláudio (I.ii.10-12), onde vários oximoros são empregados. O rei fala em "alegria frustrada", em "um olho que ri e outro que chora" e na "alegria no funeral e hinos fúnebres no casamento". Na adaptação, há uma redução significativa do texto dramático, mas o emprego dessa figura de pensamento é mantido através dos emojis faciais (estrutura representacional ideográfica).

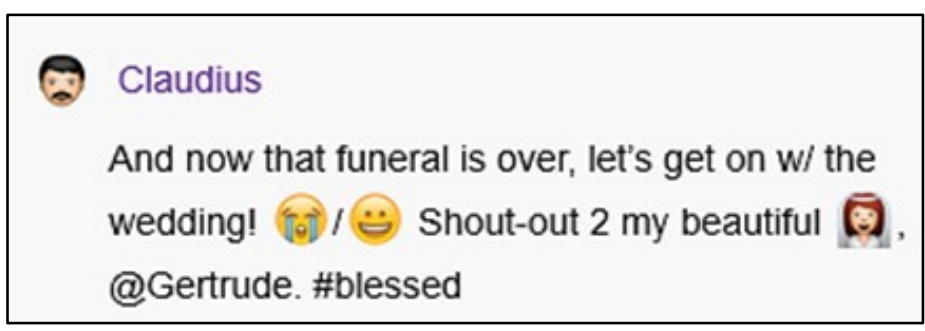

Figura 22 - Oximoro ${ }^{83}$

Fonte: SHAKESPEARE; CARBONE, 2015, p. 8

O emprego de alguns pictogramas encontra-se associado à figura de linguagem chamada sinédoque, onde uma parte substitui o todo. Usa-se, por exemplo, 8 para se referir ao rei, 49 para indicar animais e 8 para denotar casamento. Nesses casos, embora haja uma semelhança entre os signos e os objetos que representam (diagramas fortes), a função predominante é a indicial. A função da linguagem pode ser associada ao signo indicial porque uma das situações em que há contiguidade (aspecto indicial) ocorre a partir de uma relação de redução entre os termos (GRAVELLS, 2017, p. 205).

Marcia A. P. Martins (2016, p. 287), em artigo sobre a tradução dos trocadilhos shakespearianos, observa que o dramaturgo levou ao extremo "o gosto elisabetano pelos jogos de palavras, brincando com a materialidade da língua e explorando com especial talento e habilidade as relações entre significantes e possíveis significados". Hamlet, com cerca de 90 trocadilhos, é o personagem que faz maior uso desse tipo de recurso retórico nas tragédias (MAHOOD, $1988^{84}$ apud MARTINS, 2016, p. 290). Em seu estudo, Martins elenca quatro tipos de

\footnotetext{
${ }^{83}$ Cláudio: E agora que o funeral acabou, vamos continuar c/ a cerimônia de casamento! Mandem um alô p/ minha bela $\mathbf{2}$, \#Gertrudes.\#abençoada.

${ }^{84}$ MAHOOD, M. M. Shakespeare's Worldplay. London: Routledge, 2003.
} 
trocadilhos: homônimos (grafia e som idênticos, mas sentidos distintos), homófonos (mesma pronúncia, mas grafia e sentidos diferentes), homógrafos (grafia igual, mas som e sentidos diferenciados) e parônimos (leve diferença na grafia e na pronúncia). A partir do momento que duas interpretações são possíveis, a ambiguidade e a incerteza presentes na peça são reforçadas. Tal recurso, embora em menor quantidade, aparece em srsly Hamlet. Um trocadilho extremamente famoso que foi reconstruído na adaptação é criado pela iconicidade fonética (homofonia) son/sun e traz uma crítica ao rei. Neste caso, o emoji torna-se um logograma. De acordo com o escritor Adam Sternbergh (2014), enquanto o pictograma é a representação literal de um objeto, o logograma é um símbolo que representa uma palavra. Em "Actually, I am too much in the ("Na verdade, eu estou perto demais do (SHAKESPEARE; CARBONE, 2015, p. 11), o emoji não se refere ao objeto "sol", mas à sequência fônica da palavra, que permite dois sentidos.

Carbone faz uso de um trocadilho do tipo parônimo na passagem onde Hamlet pede que Horácio e Marcelo não falem sobre o encontro com o fantasma. A autora transforma um momento solene em uma brincadeira ao mostrar que o corretor de texto trocou swear (jurar) por sweat (suar). Embora talvez não tenha sido a intenção dela, essa brincadeira parece introduzir uma das questões da peça, que é o esvaziamento de sentidos no discurso da corte dinamarquesa. $O$ juramento, na peça (I.v), é uma fala performativa; discurso e ação formam uma unidade através da realização de um ritual (mão colocada sobre a espada). Em srsly Hamlet, o significado do juramento é esvaziado, a ação torna-se apenas uma cópia do significante. É interessante destacar que Hamlet faz uso do termo sweat em duas passagens da peça (III.i.76 e III.iv.90) e, em ambos os casos, a palavra apresenta uma visão considerada negativa (sofrimentos terrenos e sexualidade de Gertrudes). Pode-se, então, considerar essa brincadeira como um prelúdio da tensão entre a moral de Hamlet e o comportamento da corte. 


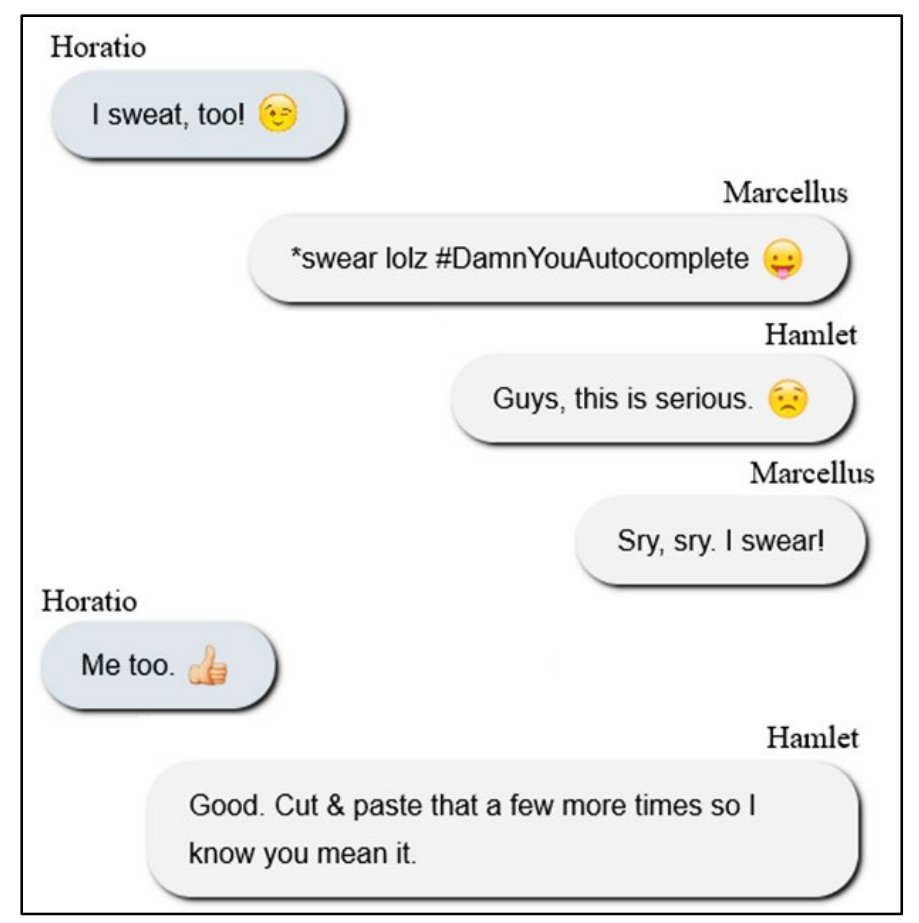

Figura 23 - Jogo de palavras ${ }^{85}$

Fonte: SHAKESPEARE; CARBONE, 2015, p. 26-27

Interessante destacar que Carbone acrescentou dois jogos de palavras na fala de Cláudio. Após o assassinato de Polônio, o "stab us in the back." ("apunhalar-nos pelas costas") na passagem a seguir traz o sentido literal e a ideia de traição. O comentário da rainha, assim como a peça Morte de Gonzago, tem uma função metalinguística, ou seja, destaca a duplicidade presente na fala de Cláudio e em toda a obra. Cláudio traz, então, um novo trocadilho, layup (tipo de arremesso no basquetebol ou tarefa fácil). Carbone parece usar essa figura de linguagem para trazer o lúdico após um evento violento. Com relação aos emojis, o único que não atua como reforço de sentido é o facial. Esse pictograma tem como função indicar o estado de espírito de Cláudio e, por conseguinte, revelar que o comentário feito era uma brincadeira.

\footnotetext{
${ }^{85}$ Horácio: Eu suo também! :

Marcelo: *juro rsrsrs \#MalditoCorretor $\odot$

Hamlet: Rapazes, isto é sério.

Marcelo: Dsclp, dsclp. Eu juro!

Horácio: Eu também. \&

Hamlet: Bom. Copiem \& colem o juramento algumas vezes para eu saber que vocês estão falando a sério.
} 


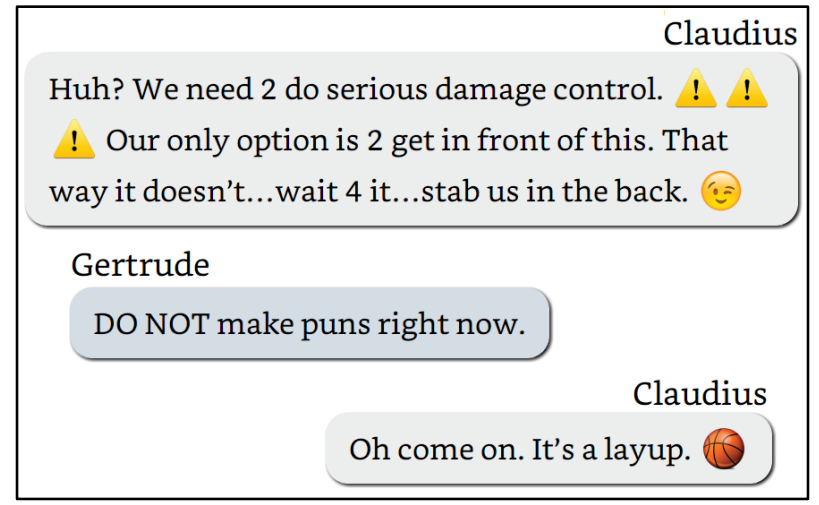

Figura 24 - Trocadilhos ${ }^{86}$

Fonte: SHAKESPEARE; CARBONE, 2015, p. 67

Vale a pena mencionar que o uso de pictogramas em alguns trocadilhos parece reduzir o seu poder polissêmico. Quando Cláudio pergunta onde Hamlet colocou o corpo de Polônio, o príncipe apresenta uma charada, através de um jogo de palavras, para indicar o local. Polônio está na ceia (supper), não como convidado, mas como comida para os vermes. A presença do emoji "coxa de ave" quebra um pouco a brincadeira com a palavra, pois enfatiza apenas uma das possíveis interpretações. Somente a explicação verbal posterior retoma o duplo sentido que o termo apresenta no contexto.

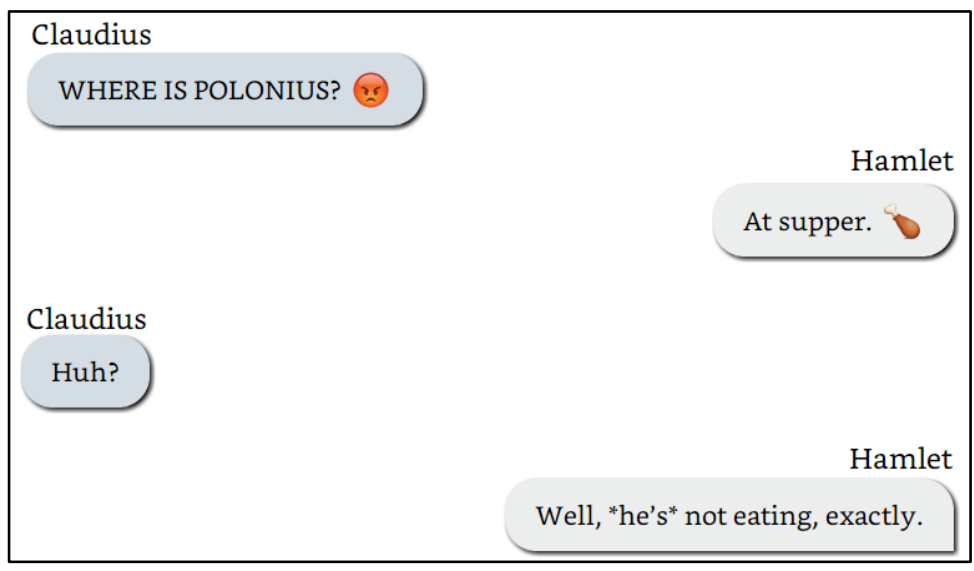

Figura 25 - Redução do potencial de duplicidade ${ }^{87}$ Fonte: SHAKESPEARE; CARBONE, 2015, p. 69-70

\footnotetext{
${ }^{86}$ Cláudio: Hã? Vamos ter que fazer um sério controle de danos, 1 \& \& Nossa única opção é nos anteciparmos. Assim não se...espera até que...nos esfaqueie pelas costas. :-0 Gertrudes: NÃO faça trocadilhos neste momento.

Cláudio: Oh, qual é. É de bandeja. (2).

${ }^{87}$ Cláudio: ONDE ESTÁ POLÔNIO?

Hamlet: Na ceia.

Cláudio: Hã?

Hamlet: Bem, “ele não está” propriamente comendo.
} 
A peça Hamlet pode ser considerada uma metáfora que expõe a relação entre realidade e representação, entre fato e ilusão, entre o observado e o observador, e entre os elementos que constituem a apresentação teatral (ator, dramaturgo, diretor e público). O estudioso Harold Bloom (2011, p. 40) destaca que "[...] a metáfora é o instrumento que Shakespeare usa não só para a criação linguística, mas também para o pensamento" ${ }^{88}$ e acrescenta que Shakespeare "pensa por meio de seus personagens e os mais intensos deles pensam através e por metáforas" ${ }^{\text {}}$. Embora Carbone espelhe esse paralelismo entre realidade e ficção em sua adaptação, há uma significativa redução no uso de estruturas metafóricas em sua obra. Tal aspecto parece corroborar o que já foi discutido nesta dissertação a respeito das estratégias empregadas na adaptação, ou seja, como as metáforas demandam processos cognitivos mais profundos, elas podem ter sido evitadas a fim de se adequar às supostas habilidades de leitura e compreensão dos leitores implícitos. É plausível afirmar que tanto em Hamlet quanto em srsly Hamlet a similaridade na relação paralela entre os signos que constituem a metáfora baseia-se principalmente em aspectos convencionais. A provável diferença no emprego das metáforas nas duas obras deve-se ao fato que os signos na peça shakespeariana são verbais, e na obra de Carbone há a presença de signos visuais. Ao matar Polônio, por exemplo, Hamlet usa o emoji "rato" para fazer a comparação entre o conselheiro e o animal: "It was Polonius. That ! ("Era Polônio. com a ideia de alguém desleal e traiçoeiro é o diagrama visual (hipoícone) que estabelece uma relação paralela com a representação de um objeto cognitivo/interno (traição). Ao contrário da associação entre Polônio e um rato, presente na peça, a comparação entre Laerte e uma ferramenta, "Laertes is such a " (SHAKESPEARE; CARBONE, 2015, p. 91), só ocorre na adaptação. Essa metáfora traz um grau de complexidade maior porque, embora a unidade metafórica seja um hipoícone, o signo visual é predominantemente indicial. Conforme foi discutido quando abordei a figura de linguagem sinédoque, trata-se de um signo que representa toda a classe de ferramentas. O leitor precisa interpretar essa relação para, em seguida, identificar que a comparação entre Laerte e uma ferramenta se dá porque ambos não conseguem pensar, não têm consciência de que são manipulados.

\footnotetext{
88 "[...] metaphor is Shakespeare's instrument both for language making and for thinking." 89 "[...] thinks through his characters, and the strongest of them think by and with metaphor."
} 
A partir daí, surge a possível interpretação de que Hamlet ofende Laerte ao chamálo de idiota.

Embora a quantidade de figuras de linguagem empregadas na adaptação seja bem inferior à encontrada na peça shakespeariana, tais recursos contribuem para a linguagem poética do texto adaptado. A ambiguidade não está presente apenas no texto verbal, uma vez que os emojis também possuem um potencial para a indeterminação (DANESI, 2017, p. 28) associado a fatores culturais. Além de trazer uma releitura da natureza imprecisa da linguagem shakespeariana, Carbone brinca com a essência ambivalente dos códigos de comunicação em passagens da narrativa que podem ser consideradas metalinguísticas. De certo modo, tal postura emula a de Shakespeare em sua peça, isto é, Carbone toma o modelo shakespeariano que reconhece a natureza viva da linguagem (verbal ou visual) e, como o Bardo, é capaz de fazer uso desse poder latente de forma criativa e lúdica. Um exemplo verbal dessa brincadeira polissêmica presente tanto na peça quanto na adaptação é o

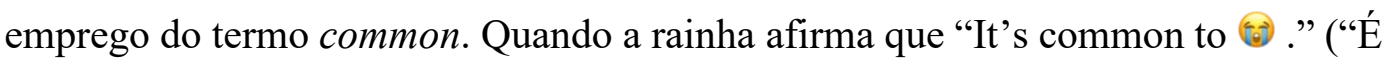
comum (․‥") (SHAKESPEARE; CARBONE, 2015, p. 11), ela usa o adjetivo para indicar algo típico e natural. Hamlet, por outro lado, parece jogar com os outros possíveis sentidos, ou seja, algo vulgar ou relacionado às classes sociais mais baixas: "Common is one word for it." (“Comum é uma palavra para isso.”) (Ibid., p. 11). Na troca de mensagens entre Horácio e Bernardo, o jogo se dá com os sentidos do vocábulo late (atrasado ou falecido).

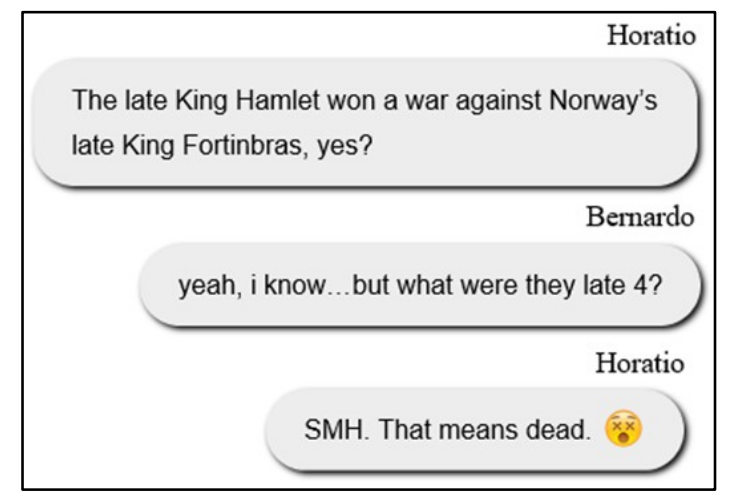

Figura 26 - Ambiguidade 90

Fonte: SHAKESPEARE; CARBONE, 2015, p. 5

\footnotetext{
${ }^{90}$ Horácio: O finado Rei Hamlet ganhou uma guerra contra o finado Rei Fortimbrás da Noruega, certo?

Bernardo: sim, eu sei...mas para o que eles estão atrasados?

Horácio: BALANÇANDO MINHA CABEÇA. Significa que estão mortos.
} 
O exemplo abaixo mostra que o emoji "batom" pode ter um sentido mais literal (icônico) ou pode funcionar como um índice transmodal ("Beijar e fazer as pazes").

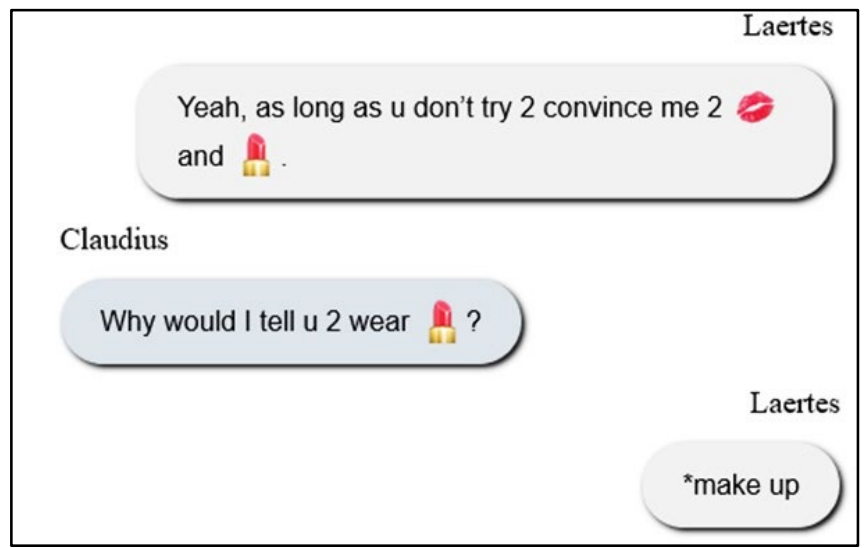

Figura 27 - Ambiguidade ${ }^{91}$

Fonte: SHAKESPEARE; CARBONE, 2010, p. 83

Apesar dos jogos de sentidos feitos graças à obscuridade das linguagens, há na adaptação uma preocupação com o controle das possibilidades de interpretação do texto, inclusive por meio da inserção de uma lista com o significado de certos emojis. Observa-se também uma tentativa de reduzir a ambivalência de certos personagens e eventos. Assim, enquanto é mantida a incerteza a respeito da morte de Ofélia (suicídio ou acidente) e do envolvimento de Gertrudes na morte do marido, a identidade do fantasma como o pai de Hamlet e a lucidez do príncipe não são colocadas em dúvida.

Um aspecto que também merece ser destacado é a presença de solilóquios. Na peça há sete solilóquios de Hamlet, um de Ofélia, dois de Cláudio e um do ator que interpreta Luciano na peça The Mousetrap apresentada em Elsinore. Além do aspecto estético gerado pela estrutura poética, eles revelam sentimentos dos personagens e suas reações aos eventos que aconteceram ou que irão acontecer. A maioria deles é uma espécie de conversa individual que não é ouvida pelos outros personagens, mesmo quando eles estão em cena. A única clara exceção é o solilóquio do ator (III.ii.248-253), por se tratar de uma encenação. Os solilóquios

\footnotetext{
${ }^{91}$ Laerte: Sim, desde que você não tente me convencer a e $\mathrm{m}$.

Cláudio: Por que eu diria para você usar $₫$ ?

Laerte: *fazer as pazes.
} 
de Ofélia (III.i.149-160), do ator (III.ii.248-253), de Hamlet após o encontro com o fantasma (I.v.92-112) e após falar com o ator (II.iii.484-540) e um de Cláudio (III.iii.97-98) não aparecem em srsly Hamlet. Os demais são apresentados de forma reduzida e no formato de bloco de notas (aplicativo de notas). O leiaute escolhido parece garantir a função do recurso literário usado por Shakespeare, ou seja, o personagem escreve uma mensagem para ele mesmo. Assim como no resto do texto adaptado, a linguagem empregada é moderna e simplificada, o que é compatível com a característica do gênero textual. Apesar das reduções e omissões, a ação dramática não ficou comprometida. Com relação ao uso de emojis nessas mensagens, pode-se dizer que quase todos atuam como logogramas e servem para completar a informação verbal de uma maneira mais divertida. $O$ trecho da mensagem de Hamlet abaixo é um exemplo da transformação do solilóquio. É interessante também destacar que Hamlet escreve que "viu" Cláudio rezando, ou seja, ele não ouviu o que Cláudio disse. Tal comentário mostra a aproximação entre os recursos usados nas duas obras. Só o público/leitor tem a confirmação da culpa do rei.

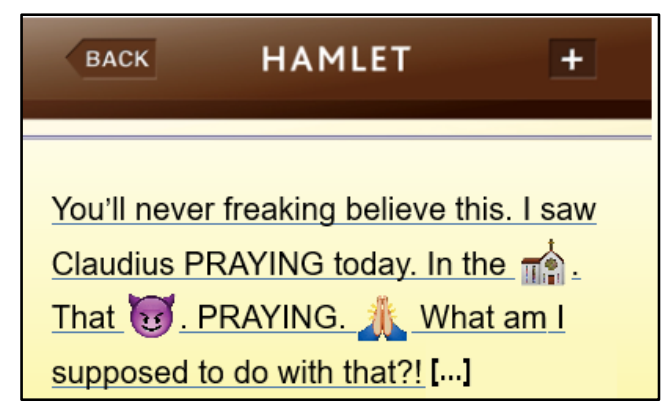

Figura 28 - Bloco de notas ${ }^{92}$

Fonte: SHAKESPEARE; CARBONE, 2015, p 54

O linguista David Crystal destaca que no século XVI houve uma expansão do vocabulário da língua inglesa, quando milhares de termos lexicais foram introduzidos a partir do grego e do latim e inúmeras palavras foram criadas seguindo as estruturas dessas duas línguas. Uma outra característica do período elisabetano é o uso de contrações na fala coloquial. Shakespeare reproduziu a tendência de sua época e prosperou com ela. Ao mesmo tempo que ele fez uso de

\footnotetext{
${ }^{92}$ Você não vai acreditar nisto. Hoje eu vi Cláudio REZANDO. Na דึîi. Aquele (3) . REZANDO. O que eu devo fazer sobre isso?! [...].
} 
arcaísmos em suas obras, ele também criou cerca de 1.700 palavras (dicionarizadas posteriormente). Além de criar termos, o Bardo também costumava empregar palavras que ainda não tinham sido usadas em outras obras (CRYSTAL, 2008, p. 9-10, 137).

Carbone, em srsly Hamlet, não trouxe os diferentes níveis de formalismo, as indicações de classe social e o número de arcaísmos presentes na peça, talvez porque a sociedade atual e o contexto de sua obra não permitissem fazê-lo. Contudo, ambas as obras compartilham o uso inovador e dinâmico da linguagem. Enquanto na obra de Shakespeare são neologismos literários, a obra de Carbone apresenta inúmeros neologismos populares formados pelo processo de abreviação de palavras e expressões e pelo emprego de emojis. No exemplo abaixo, é possível identificar a linguagem oral informal através da omissão de elementos gramaticais e do emprego da contração Rly (Realmente). O sinal tironiano (\&) também é um exemplo de abreviação, embora sua utilização seja apenas em textos impressos. O uso das siglas $G 2 G$ (Tenho que ir) e $F M L$ (Droga de Vida), do algarismo 2 (too e to) e dos emojis traz o aspecto inovador, ou seja, a transferência de termos característicos da internet (chat slang) para a literatura impressa. Observa-se também a presença da ironia quando Cláudio afirma que está feliz. O uso dessa figura de linguagem é muito comum em Hamlet, e Carbone a recriou em inúmeros momentos da adaptação. Merece também destaque a metáfora convencional do tempo através do emoji “despertador".

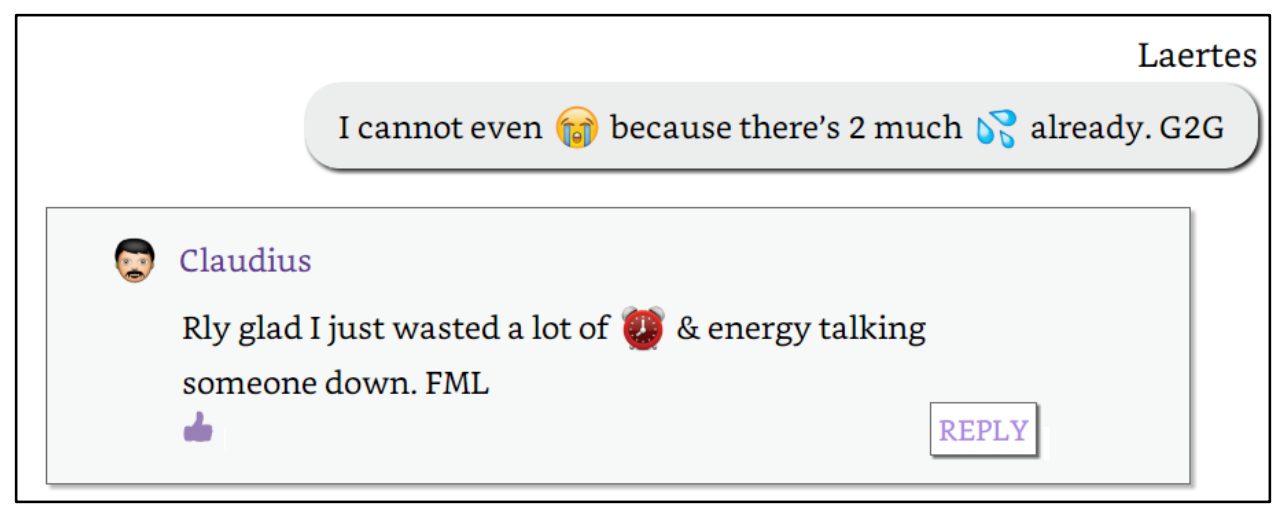

Figura 29 - Elementos da linguagem de Shakespeare ${ }^{93}$ Fonte: SHAKESPEARE; CARBONE, 2015, p.86

${ }^{93}$ Laerte: Eu sequer consigo ${ }^{010}$ pq já há muita $0^{\circ}$. Tenho que ir Cláudio: Muito feliz por ter perdido tanto \& energia persuadindo alguém. DROGA DE VIDA. 
Pode-se afirmar que srsly Hamlet não é uma imitação de Hamlet. Assim como Shakespeare baseou-se em outras obras para criar a sua visão de Hamlet e da corte dinamarquesa e apresentá-la no The Globe inglês, Carbone fez o mesmo, ou seja, ela fez a transposição de história, tramas, personagens e linguagem para o mundo digital dos jovens. A proposta da série $O M G$ Shakespeare não é transformar os leitores em groundlings da era elisabetana, mas oferecer lentes que permitam acessar essa realidade. Isso não significa, no entanto, que aquilo que parece caracterizar a linguagem do Bardo não esteja presente. Como procurei demonstrar neste capítulo, vários traços presentes na obra shakespeariana ganharam uma nova roupagem e se adequaram ao novo espaço e tempo. Afinal de contas, de acordo com Crystal (2008, p. 233), Shakespeare nos mostra como ousar fazer coisas com a linguagem, como inventar palavras para expressar o inexprimível, como manipular as classes gramaticais e as estruturas sintáticas e como quebrar as regras. 


\section{5}

\section{Aspectos intermidiáticos e multimodais na adaptação}

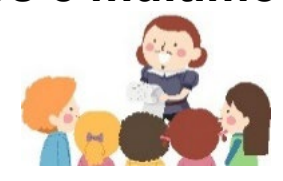

\section{1}

\section{O palco elisabetano e a plataforma digital}

Já foi discutido em capítulos anteriores desta dissertação que a obra de Carbone pode ser considerada, dentro da categorização proposta por Irina Rajewsky (2005), uma transposição, já que é um texto no formato de mensagens criado a partir de uma peça de teatro. A obra também se encaixa na categoria referência intermidiática porque, embora seja um texto impresso, ela imita um aplicativo de mensagens instantâneas. A presença da mídia fotografia no corpo da obra reflete a natureza híbrida da mídia que está sendo imitada, reforçando, assim, a sua presença no texto adaptado. A opção por imitar uma mídia heterogênea propicia uma aproximação ainda maior com a mídia do texto-fonte, ou seja, o teatro. Pode-se afirmar que, por adotar estratégias que buscam apresentar características da peça shakespeariana, Carbone faz evocações ao teatro. Tais referências, explícitas ou não, permitem que o texto adaptado também dialogue com essa mídia.

Em primeiro lugar, a autora manteve a dicotomia presente na peça entre atuação e essência. Na linguagem verbal isso fica claro logo no início de srsly Hamlet, quando Hamlet afirma que dali em diante ele estará atuando ("I will be acting (- ”) (SHAKESPEARE; CARBONE, 2015, p. 28), o que pode ser interpretado como estar se comportando de forma maluca ou estar agindo propositalmente como tal. Em “ dress up and dumb down. It's all so fake" (“\$ arrumam-se e emburrecem. 2 e falam como . É tudo tão falso") (Ibid., p. 45), o uso das expressões dress up (vestir-se com elegância ou fantasiar-se) e fake (falso) e dos emojis de elementos de maquiagem para indicar atuação e dissimulação trazem as máscaras do teatro para o texto.

Um elemento encontrado tanto na dramaturgia shakespeariana como em peças infantis que reforça a oposição entre aparência e realidade no texto é a quebra da quarta parede, ou seja, é a comunicação direta de um ou mais personagens com o público. Além dos apartes presentes na obra de Carbone, a impossibilidade de se 
reproduzir todas as qualidades do aplicativo revela a natureza irreal do texto. A mensagem de Polônio abaixo é para o leitor. Ele revela a sua avaliação sobre a loucura de Hamlet. O fato de não ser possível clicar no botão para fazer um comentário demonstra o rompimento com a convenção do aplicativo de mensagens. Esse rompimento, de certa forma, amplia a presença da mídia teatro na adaptação.

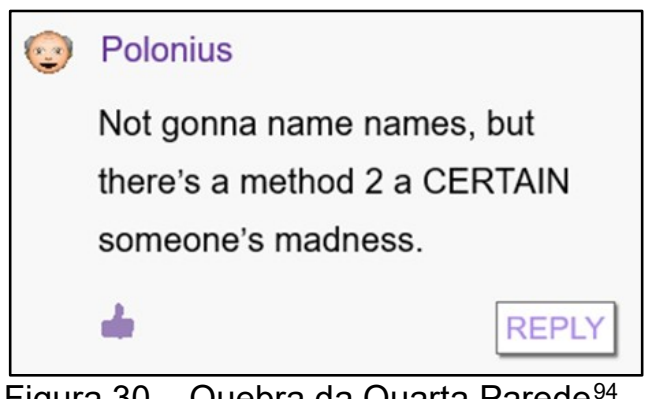

Figura 30 - Quebra da Quarta Parede ${ }^{94}$

Fonte: SHAKESPEARE; CARBONE, 2015, p. 38

A referência a apresentações em srsly Hamlet não está evidente apenas na narração da peça organizada por Hamlet no teatro do castelo Elsinore (CARBONE, 2015, p.48-49), mas também quando o príncipe pede a Guildenstern um vídeo com uma exibição musical e no duelo transmitido ao vivo por Horácio (ibid., p. 50, 94). Merece também ser mencionado que Shakespeare, como Camati (2011, p. 127) salienta, "insere dimensões metateatrais na estrutura dramática e nas falas dos personagens que podem ser lidas como comentários críticos sobre as cenas". $\mathrm{Na}$ adaptação, além dos apartes e dos comentários dos personagens sobre a peça encenada no castelo, alguns elementos na história parecem ter uma dupla função, ou seja, fazem parte da narrativa e remetem ao processo de encenação. Quando Horácio dirige-se ao público e diz que aquilo nunca foi visto antes e que provavelmente nunca mais seria visto, ele se refere ao duelo entre Hamlet e Laerte. Contudo, tal comentário parece espelhar a própria representação no palco, onde as atuações nunca são as mesmas. A vaia em um momento anterior e a afirmação do povo/público de que valeu a pena o dinheiro gasto, em uma espécie de compra de ingressos, reforça tal impressão porque apresenta possíveis comportamentos da audiência elisabetana.

\footnotetext{
${ }^{94}$ Polônio: NÃO vou citar nomes, mas há método na loucura de uma CERTA pessoa.
} 


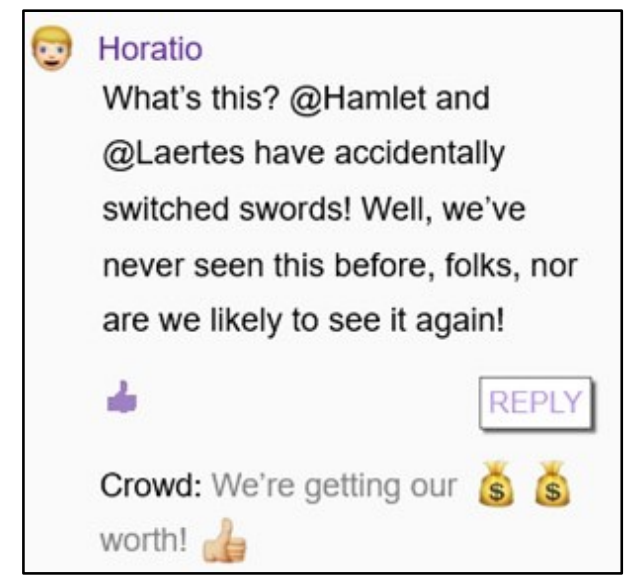

Figura 31 - Encenação e público ${ }^{95}$

Fonte: SHAKESPEARE; CARBONE, 2015, p.96

O espaço virtual criado através de uma ilusão perceptual, já analisado no segundo capítulo, permite não só a reprodução de características da plataforma digital, mas também um diálogo com o teatro, onde os personagens atuam e há o engajamento perceptivo da plateia/leitor. Assim como no teatro, a adaptação estabelece com o público uma relação simbólica de "como se". O ambiente de diálogo face a face caracteriza não só as mensagens do aplicativo apresentadas na adaptação, mas também a atuação na mídia teatro. Assim, para analisar as estratégias empregadas na reprodução das duas mídias em srsly Hamlet, além da linguagem verbal, é preciso discutir a cinésica (linguagem corporal) e a paralinguagem. Pode-se afirmar, com relação à qualidade paralinguística, que Carbone fez uso dos recursos gráficos, sinais de pontuação e marcadores conversacionais. Nas mensagens abaixo, o uso de maiúsculas marca o aumento do tom de voz de Hamlet resultante de sua surpresa e raiva pelo fato de a mãe não ver as mensagens do fantasma. As alterações nas modulações de voz causadas pelos mesmos sentimentos também são indicadas pelos pontos de interrogação e de exclamação. O uso de um marcador conversacional não lexical ("Um”) e de reticências indicam o início da fala de Gertrude e sua hesitação. Posso concluir, então, que esses elementos agregam oralidade e emoções ao texto.

\footnotetext{
95 Horácio: O que é isto? @Hamlet e @Laerte acidentalmente trocaram as espadas! Bem, nós nunca vimos isto antes, pessoal, nem provavelmente iremos ver novamente!

Povo: Está valendo a pena o (s) que gastamos!
} 


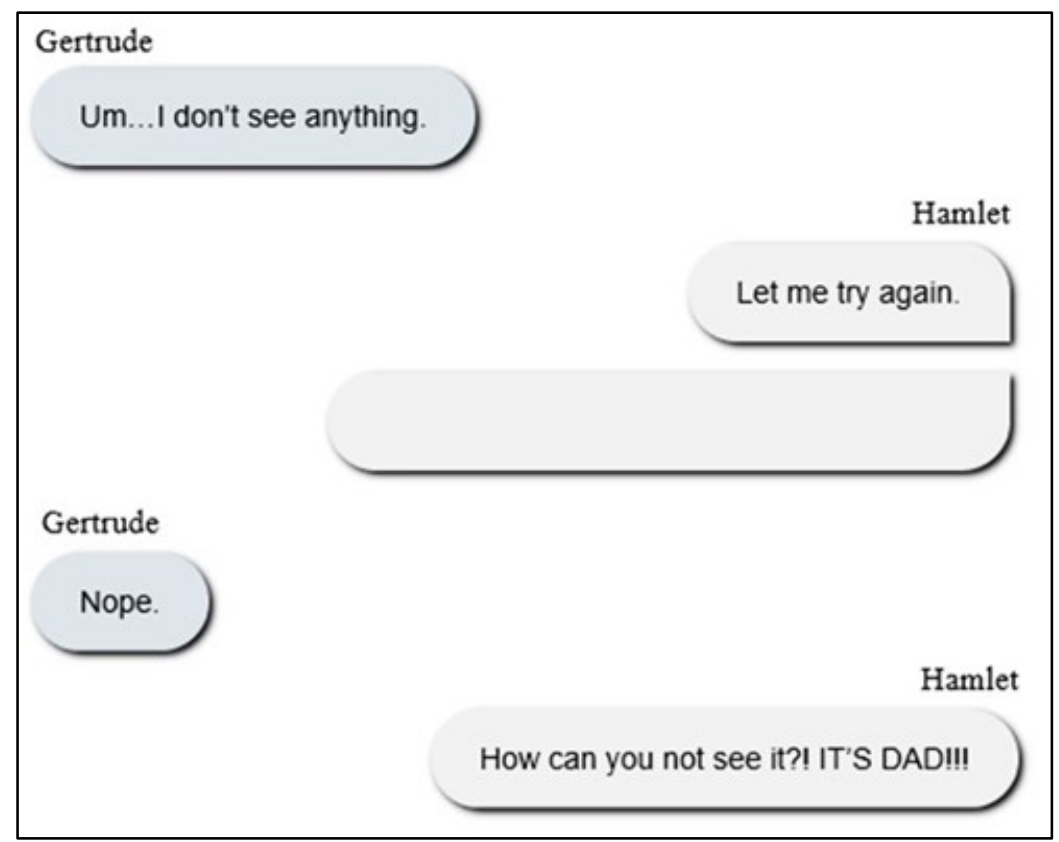

Figura 32 - Elementos paralinguísticos ${ }^{96}$

Fonte: SHAKESPEARE; CARBONE, 2015, p. 62-63

Gestos, expressões faciais e postura não podem ser ignorados ao se discutir comunicação. O corpo humano faz parte da modalidade material do teatro e é essencial para a construção dos significados nessa mídia. Evans (2017) aponta que vários dos sentidos dos gestos usados nas interações cotidianas estão associados a aspectos culturais, e destaca seis principais funções desempenhadas pelos elementos cinésicos nessas interações que também são executadas pelos pictogramas. Através do uso de emojis, fotografias e palavras, essas mesmas funções podem ser encontradas na obra de Carbone. A primeira delas é a de substituição. Em “[...] it's 4 Denmark”) (“[...] é $\mathcal{P}$ p/ a Dinamarca”) (SHAKESPEARE; CARBONE, 2015, p.4), o gesto apresentado pelo pictograma substitui o termo ruim. Isso também é observado no gesto usado por Polônio para indicar que concorda com a viagem do filho: “ by me” (Ibid., p. 10). É preciso apontar, no entanto, que o sentido dos gestos/emojis não só varia nas diferentes culturas, podendo ser ofensivos para algumas, mas através dos tempos. O gesto que expressa o termo $O K$ e o emoji que representa esse movimento, por exemplo, podem

\footnotetext{
${ }^{96}$ Gertrudes: Uhn...não vejo nada.

Hamlet: Deixe-me tentar novamente,

Gertrudes: Nada.

Hamlet: Como você não consegue ver? É PAPAI!!!!
} 
estar atualmente associados a símbolos de ódio racial na Internet (DANTAS, 2019). $\mathrm{Na}$ obra de Carbone, entretanto, esse pictograma parece produzir uma interpretação tradicional.

Alguns elementos cinésicos expressos por emojis são empregados para reforçar o que é dito verbalmente; trata-se da função de reforço. Após o juramento de Marcelo, Horácio não só confirma o seu voto através de palavras, mas gesticula

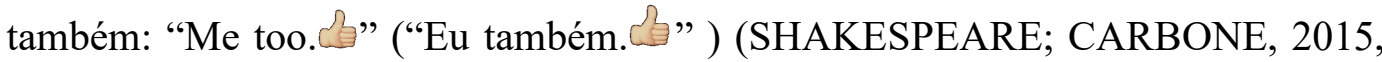
p.27). Uma outra estratégia de reforço é a repetição. Em sua competição para provar seu amor por Ofélia, Hamlet e Laerte repetem os emojis "coração".

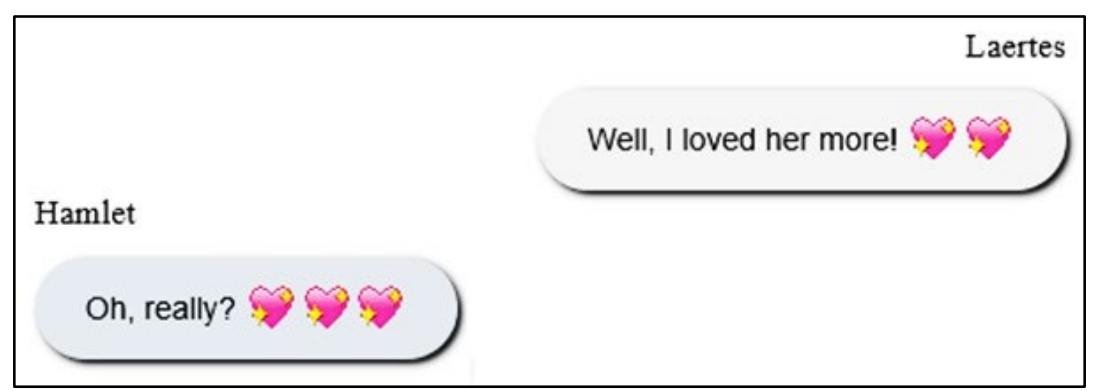

Figura 33 - Função de reforço dos pictogramas ${ }^{97}$

Fonte: SHAKESPEARE; CARBONE, 2015, p. 90

Por outro lado, em algumas situações, as linguagens verbal e gestual são empregadas para transmitir uma mensagem contraditória, o que geralmente introduz humor ou ironia. Na mensagem de Laerte, após uma brincadeira de Ofélia, tem-se a onomatopeia da risada, indicando que achou divertido o comentário. As pausas marcadas pela pontuação e o emoji "rosto sem expressão", que geralmente é empregado para indicar tédio, falta de paciência ou até mesmo irritação, transmitem uma ideia contrária. Assim, Laerte indica, de forma irônica, que não achou engraçada a brincadeira: "Ha. Ha. Ha. $\odot$ " (SHAKESPEARE; CARBONE, 2015, p. 17).

A quarta função desempenhada pelos pictogramas é a de ênfase. Quando Cláudio pede ajuda a dois membros da corte, o uso do emoji acentua o pedido: "I need u guys. $\mathbb{d}$ " ("Eu preciso de vcs rapazes.

\footnotetext{
${ }^{97}$ Laerte: Bem, eu a amava mais!

Hamlet: Oh, é mesmo?
} 
fornecem metacomentários, ou seja, dicas de como a mensagem deve ser interpretada. Essa função complementar pode atenuar os aspectos negativos da mensagem e/ou expressar a atitude emocional em relação à própria mensagem. Abaixo, nas mensagens sobre Hamlet usar os atores que chegaram ao castelo, o emoji "feliz" usado por Guildenstern parece não só indicar a emoção do personagem por ajudar Hamlet, mas, ao mesmo tempo, reforçar a expressão de se “sentir melhor". Já o pictograma com o sorriso pretensioso usado por Hamlet indica que sua satisfação não está vinculada à apresentação teatral, como suas palavras parecem indicar, mas a algo que ele não deseja revelar.

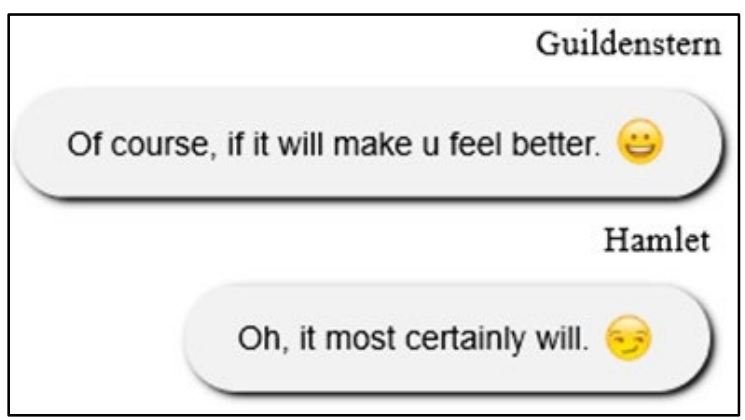

Figura 34 - Função complementar dos emojis ${ }^{98}$ Fonte: SHAKESPEARE; CARBONE, 2015, p. 40

A última função dos gestos elencada por Evans refere-se à gestão das interações orais. Quando o emoji aparece no início da mensagem, geralmente se trata de uma resposta a um comentário anterior. Ao usar os três emojis do macaco, por exemplo, Horácio responde ao pedido de Hamlet, ou seja, ele indica que nada

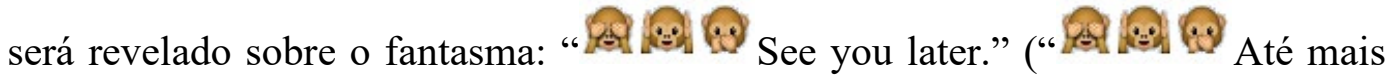
tarde.”) (SHAKESPEARE; CARBONE, 2015, p. 16). A autora de srsly Hamlet também fez uso da linguagem verbal para representar a gestual. Na passagem "SMH. That means dead. (x)" ("SMH. Isso quer dizer que ele está morto. 장") (Ibid., p.5), Horácio usa a sigla $S M H$ (Balançando minha cabeça) para indicar que o comentário de Marcelo é estúpido. Em outro momento, Hamlet utiliza a palavra shrug (dar de ombros) para indicar sua indiferença quanto à participação no duelo:

\footnotetext{
${ }^{98}$ Guildenstern: Claro, se fizer vc se sentir melhor.
}

Hamlet: Oh, certamente fará. 
(“*shrug* Why not?”) (“*dar de ombros* Por que não?”) (SHAKESPEARE; CARBONE, 2015, p. 93). É interessante destacar que a indicação de uma ação através do uso de palavras entre asteriscos nas conversas virtuais parece espelhar a rubrica do texto teatral.

O emoji na função de gestão da comunicação oral também pode aparecer no final do enunciado. Nesse caso, ele indica o fim de uma ideia. Um claro exemplo desse emprego pode ser encontrado na passagem onde Cláudio usa a sigla Ttyl (Falo com você depois) e a mão acenando para indicar o fím da conversa com Laerte sobre a viagem para Paris: "Laertes u r free 2 go. Ttyl. "U"” ("Laerte vc está livre p/ ir. Falo com vc + tarde. ") (SHAKESPEARE; CARBONE, 2015, p. 10).

Os movimentos, posturas e expressões faciais são tão importantes na obra de Carbone que a autora emprega duas fotos para apresentar a comparação feita por Hamlet entre seu pai e Cláudio. Na peça de Shakespeare, Hamlet, através de símiles e metáforas, compara o pai a deuses romanos e a uma montanha. Já o tio é apresentado como uma charneca e uma espiga de milho mofada (III.iv.51-65). Em srsly Hamlet, a metáfora passa a ser visual. Através da postura, das expressões faciais e das roupas é feito o contraste entre os irmãos; entre o passado glorioso e o presente corrupto. O pai de Hamlet, em uma armadura feudal, apresenta uma aparência conservadora e confiante na fotografia (está em pé com o tronco ereto). Parece indicar que está pronto para a ação. Desse modo, mantém-se a visão clássica na descrição do falecido Hamlet. Cláudio, por outro lado, usa roupas modernas e mais informais. Sua postura (mãos no queixo e olhos voltados para cima) parece tentar destacar o rosto (sua suposta beleza) e chega a ser quase infantil. O fato de Hamlet mencionar que Cláudio usa vários filtros reforça a ideia de falsidade associada a Cláudio. $\mathrm{O}$ espaço presente nas fotografias também contribui para a construção da metáfora cognitiva. Enquanto o pai de Hamlet está em um local aberto (visualização do céu), o retrato de Cláudio só revela o corpo dele. A questão de o retrato de Cláudio ter como único elemento composicional partes do corpo e o modo como foi editado podem não só indicar a vaidade e a falsidade de Cláudio, mas também transmitir uma ideia de confinamento, de prisão, o que espelha a sensação de Hamlet na peça. 


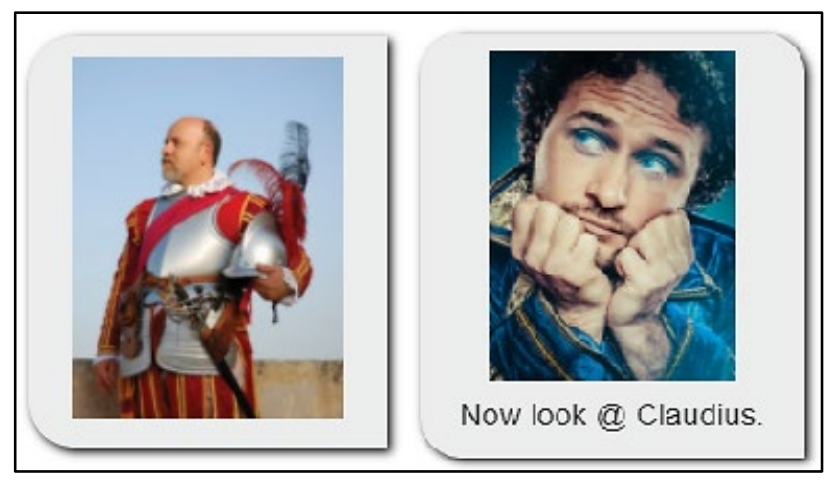

Figura 35 - Postura como metáforas

Fonte: SHAKESPEARE; CARBONE, 2015, p. 60

Já foi discutido anteriormente que srsly Hamlet é uma obra inserida em uma única mídia convencional, ou seja, o livro impresso. Contudo, pelo que foi abordado nesta seção, é possível afirmar que ela faz referência a duas outras mídias distintas, o aplicativo de mensagens e o teatro. O texto adaptado replica a multiplataforma digital, mas também faz alusões à encenação teatral e recria algumas de suas características. A própria natureza multimodal e multimidiática do aplicativo imitado propicia a aproximação com o teatro. A mídia dominante é o livro impresso, uma vez que é a única mídia material existente (há restrições técnicas em relação às outras duas). Embora as duas mídias representadas dependam do leitor para a sua percepção, a constatação das alusões teatrais é mais difícil, uma vez que elas estão intrinsecamente vinculadas à mídia digital. Entretanto, o reconhecimento desses dois meios fornece significações diferentes ao texto. Ao apresentar o texto em mensagens instantâneas, traços como dinamicidade, oralidade, informalidade e diversão são agregados à obra. Já a presença de menções e de características teatrais não só aproxima o leitor contemporâneo do espaço onde as peças do Bardo eram encenadas, mas também reforça um dos temas centrais de Hamlet, ou seja, a oposição entre aparência/encenação e essência/realidade.

\section{2}

\section{A multimodalidade e a transmodalidade em srsly Hamlet}

Ao se discutir a adaptação de Carbone, já foi verificado que ela é múltipla em três modalidades apresentadas por Elleström. A obra só é monomodal em sua materialidade, isto é, tanto o livro físico quanto o eletrônico são superfícies planas bidimensionais. Embora a natureza de srsly Hamlet não seja, em princípio, 
temporal (o texto é estático), com relação à modalidade espaçotemporal, foi possível constatar que a adaptação apresenta espaço e tempo não só relacionados com a interface da obra, mas também cognitivos (sempre presentes) e virtuais. Pode-se dizer que srsly Hamlet deixa de ser estático (duas dimensões) e, através de ilusões perceptuais e da linguagem verbal, agrega profundidade e tempo. Já em sua qualidade semiótica (representação), o texto adaptado engloba os modos contiguidade, semelhança e convenção.

Em um primeiro momento, parece haver um predomínio da função simbólica em srsly Hamlet, uma vez que há uma dominância da linguagem verbal escrita. Além disso, os próprios emojis, por serem controlados pela Comissão do Consórcio UNICODE, apresentam uma natureza convencional. Na realidade, pode-se afirmar que os signos verbais e pictográficos muitas vezes apresentam funções sobrepostas. Nos signos verbais, os dêiticos (pronomes demonstrativos, advérbios de tempo e lugar e pronomes de $1^{\mathrm{a}}$ e $2^{\mathrm{a}}$ pessoa), por exemplo, possuem uma função simbólica (código verbal) e uma indicial referencial (há uma relação existencial que só funciona no contexto).

A mensagem de Hamlet sobre a aparição do fantasma começa com um símbolo visual que, nos seis momentos em que é empregado na adaptação, representa alterações emocionais e até certa perda de controle. Há também no exemplo abaixo vários signos indiciais, ou seja, os pronomes e advérbio de lugar têm como ponto de refência para sua interpretação o autor da mensagem e estabelecem uma relação factual com seus objetos. I e you são indicadores de pessoa (Hamlet e Horácio) e tonight (esta noite) refere-se a tempo. É até possível considerar que o dêitico espacial foi omitido, isto é, pode-se incluir o advérbio there (lá) na mensagem.

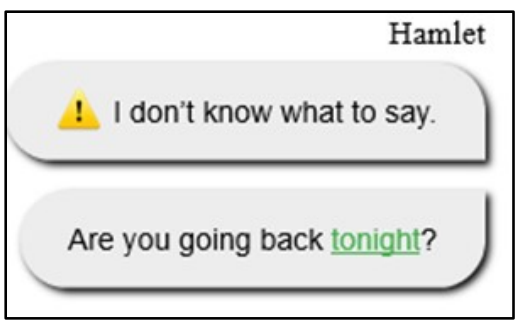

Figura 36 - Dêiticos e índices ${ }^{99}$ Fonte: SHAKESPEARE; CARBONE, 2015, p. 15

\footnotetext{
${ }^{99}$ Hamlet: ! Eu não sei o que dizer. Você vai voltar hoje à noite?
} 
A fotografia abaixo caracteriza-se, em um primeiro momento, por suas dimensões icônicas (semelhança) e indiciais (a própria mídia fotografia assegura uma relação factual com o objeto no mundo). Além disso, o sangue na foto também apresenta função indicial contígua, uma vez que representa o resultado do assassinato de Polônio.

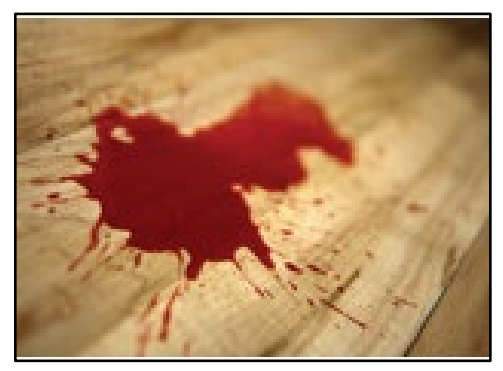

Figura 37 - Imagem icônica e indicial

Fonte: SHAKESPEARE; CARBONE, 2015, p. 59

O texto verbal, possibilitado pelo contexto comunicativo, também funciona como um índice linguístico. No exemplo abaixo, o assassinato do pai de Ofélia é representado pelo efeito de se necessitar de um advogado. Deve-se destacar que, para que ocorra a interpretação dos signos verbais e visuais como índices, é necessário um conhecimento prévio, ou seja, é preciso saber como fotos são tiradas, que ferimentos geram sangramentos e que, em crimes, advogados são os responsáveis pela defesa. Esse tipo de conhecimento que possibilita a completa significação do signo é chamado por Peirce de observação ou informação colateral (PEIRCE, 1998, p. 404-407). Além disso, a própria relação de complementaridade entre o texto linguístico e o imagético contribui para a construção da mensagem. As dimensões dos signos podem variar de acordo com o contexto e o propósito de uso. Assim, é digna de destaque a dimensão simbólica também presente no texto abaixo. Além do uso dos signos verbais, o sangue também pode ser visto como um símbolo de violência e de morte. 


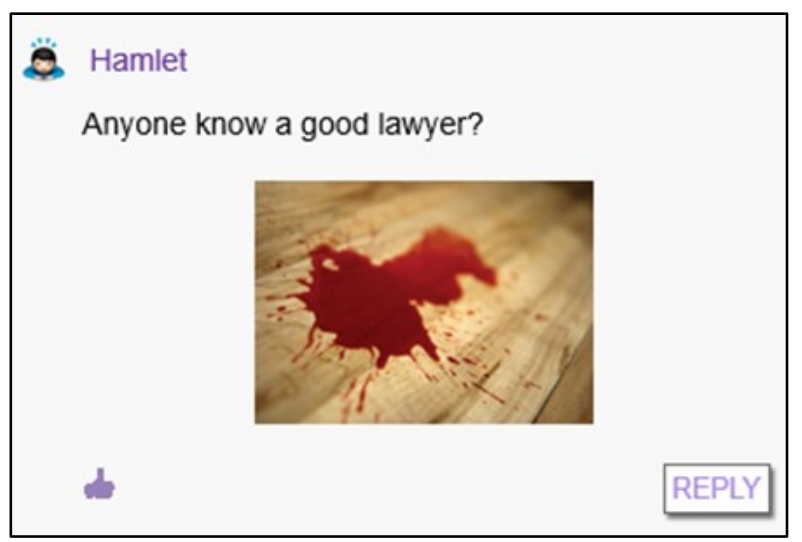

Figura 38 - Dimensões dos signos e informação colateral ${ }^{100}$ Fonte: SHAKESPEARE; CARBONE, 2015, p. 59

Por sua vez, no exemplo abaixo, os emojis apresentam uma função icônica clara, isto é, representam um prédio, uma caixa de correios e uma pilha de dinheiro voando. Contudo, a relação com o texto verbal permite a identificação da dimensão indicial dos dois pictogramas da mensagem de Reinaldo. Ao obter empréstimos estudantis, as consequências são a obrigação de envio de cheques de pagamento pelo correio (a bandeira levantada na caixa indica que há correspondência para ser recolhida) e prestações com taxas de juros (dinheiro perdido ou transferido) . Mais uma vez, é necessária informação além da fornecida pelos signos presentes para que a interpretação atinja diferentes níveis.

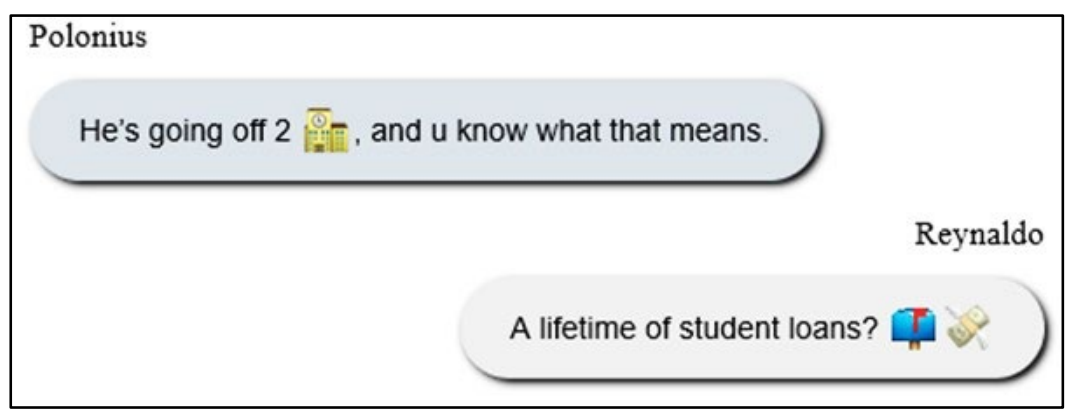

Figura 39 - Função indicial e informação colateral ${ }^{101}$ Fonte: SHAKESPEARE; CARBONE, 2015, p. 30

A cor preta empregada como fundo nas mensagens enviadas pelo fantasma também exemplifica essa mistura de funções dos signos. Como Elleström destaca,

\footnotetext{
100 Hamlet: Alguém conhece um bom advogado?

${ }^{101}$ Polônio: Ele está partindo para a ${ }^{-7}$ e vc sabe o que isso significa.
}

Reinaldo: Uma vida inteira de empréstimos estudantis para pagar? 
essa cor, por causa das convenções culturais, pode atuar não só como símbolo, mas também como ícone. Já foi visto anteriormente que essa cor simboliza a morte em várias culturas. A similaridade, por outro lado, pode estar associada à ideia de ausência (de cor ou de vida). A cor atua, então, como uma metáfora de um objeto cognitivo. É também possível elencar um elemento indexical nesse signo se for considerado que a não percepção da luz e da cor é uma das consequências da morte (ELLESTRÖM, 2017b, p. 184). Para que todas as possíveis interpretações sejam acessadas, é novamente essencial um conhecimento não só do contexto narrativo (percepção e interpretação), mas também de informações encontradas fora dele.

A necessidade de um conhecimento prévio para que certas camadas de significação sejam alcançadas parece reforçar o próprio potencial para a ambiguidade das linguagens. Marcel Danesi (2017, p. 119) destaca que essa possível variedade de interpretações provavelmente torna impossível uma comunicação feita só com emojis. Em outras palavras, sem consideráveis contextualizações verbais prévias, o tempo gasto e o esforço para a interpretação tornam-se excessivos e, muitas vezes, a compreensão não é alcançada. Essa imprecisão de sentidos não só é ampliada pela dimensão cultural, mas também pelo contexto onde o signo é utilizado. Tal fato fica bem claro em srsly Hamlet quando Ofélia fica louca. Os personagens e os leitores não conseguem ter um claro entendimento de suas mensagens porque só há signos não verbais. Um exemplo das variações de interpretação causadas pelo contexto pode ser visto no emprego do emoji "lâmpada". Quando Horácio diz para Hamlet ficar longe da (SHAKESPEARE; CARBONE, 2015, p. 99), a ideia é que ele não morra (luz no fim do túnel para outra dimensão). Trata-se de um sentido conectado a questões culturais e religiosas. Já quando Polônio escreve a lista de conselhos para Laerte e diz “ b4 u act” (“ antes de agir”) (Ibid., p. 18), a interpretação do pictograma está ligada ao ato de pensar. Ao escrever "Yeah ur rite. Let's have filled with poison 2!" ("Sim vc tá certo. Vamos encher a com veneno tbm”) (SHAKESPEARE; CARBONE, 2015, p. 84), Cláudio parece usar o emoji "lâmpada" para expressar a noção de ideia. Observa-se, então, que a função predominantemente simbólica do pictograma sofre alterações de acordo com o contexto em que está inserido. Essa variedade de sentidos parece produzir um efeito 
de difusão, isto é, a interpretação se torna fluida por causa da ambiguidade do texto. Tal fato aproxima a prosa da adaptação da linguagem poética de Shakespeare.

Apesar de a maioria dos signos poder apresentar diferentes funções no texto, é possível dizer que a iconicidade (a percepção das representações através das similaridades com os objetos) é o modo semiótico dominante nos pictogramas utilizados na adaptação, ou seja, há uma predominância de hipoícones do tipo diagrama (forte e fraco). Assim, é admissível afirmar que grande parte da construção de sentidos do texto adaptado baseia-se em estruturas icônicas. Para Elleström, a relação de semelhança entre o objeto e o representamen depende do contexto e não é universal. De certo modo, é até possível afirmar que srsly Hamlet é um hipoícone, uma vez que apresenta uma relação de semelhança com o aplicativo de mensagens e com a peça shakespeariana. Contudo, para que as diferentes esferas interpretativas dessa relação diádica sejam alcançadas é necessário um conhecimento fora do texto da obra.

A mensagem de Ofélia sobre sua relação com Hamlet abaixo claramente exemplifica o predomínio da correspondência entre os pictogramas e os objetos na obra adaptada. Quase todos os emojis são diagramas (os presentes que ela recebeu e a piscadela de olho). Somente a igreja associada ao coração tem função simbólica predominante (casamento). Tal valorização da iconicidade pode ter como causa a tentativa de facilitar a compreensão do texto para os leitores implícitos.

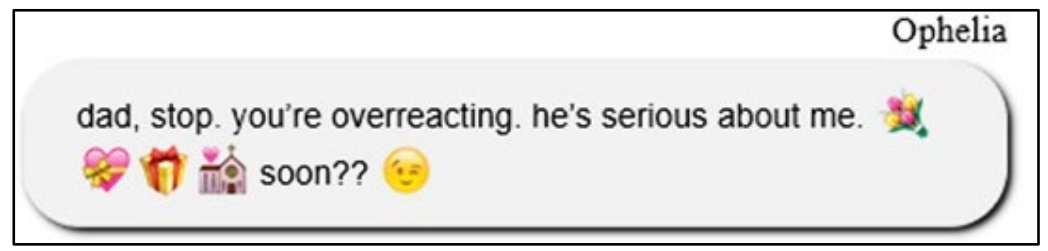

Figura 40 - Predominância da iconicidade 102 Fonte: SHAKESPEARE; CARBONE, 2015, p. 21

Um outro exemplo da força da iconicidade na adaptação pode ser visto na mensagem de Hamlet a respeito da troca de cartas na viagem para a Inglaterra. Os dois primeiros pictogramas podem ser considerados diagramas fortes. Já o emoji

${ }^{102}$ Ofélia: papai, pare. vc está exagerando. ele quer algo sério comigo. 
"faca", por representar a ação (matar) e não o objeto, pode ser considerado um diagrama fraco. É preciso mencionar que a relação de semelhança também está presente na expressão verbal que acompanha a cerquilha e que busca reproduzir uma risada maligna.

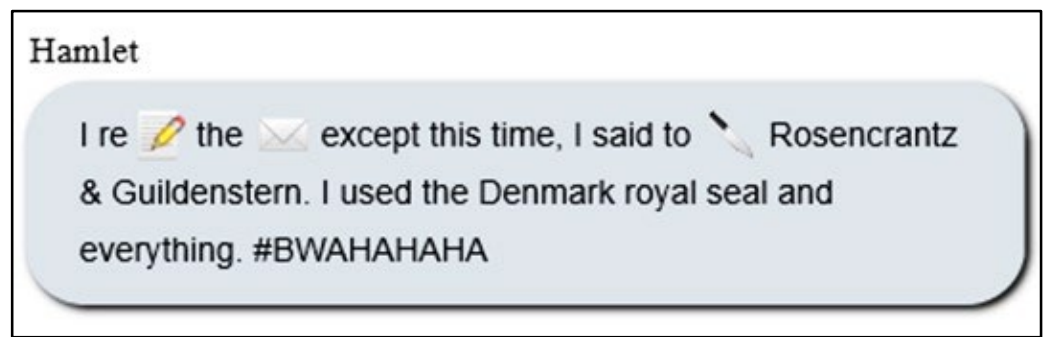

Figura 41 - Iconicidade pictográfica e verbal ${ }^{103}$ Fonte: SHAKESPEARE; CARBONE, 2015, p. 92

A preocupação com a clareza da mensagem é observada não só na valorização da função icônica, mas também na redundância de signos (verbais e imagéticos). Percebe-se claramente tal fato no uso do emoji "trevo". Embora seja um símbolo bem conhecido, ele só aparece isoladamente após ter seu possível sentido apresentado em um primeiro momento: "Good luck! \&ै" ("Boa sorte! \& ") (SHAKESPEARE; CARBONE, 2015, p. 19).

O emprego pleonástico de signos verbais e pictográficos como tentativa de controlar o processo de interpretação também é encontrado no uso do emoji "rosto atordoado" $\left({ }^{\sqrt[x]{x}}\right)$ no texto. Trata-se de um diagrama fraco cujo sentido mais comum está associado à surpresa, espanto e temor. Contudo, na adaptação, ele atua como metáfora, ou seja, sua significação remete ao falecimento e não aos significados mais fundamentados na semelhança perceptual da expressão facial. Essa possível relação com a morte repousa na utilização convencional do "X" no lugar dos olhos para indicar óbito e no próprio contexto. É curioso mencionar que ossos posicionados no formato dessa letra, junto com uma caveira, são usados para indicar morte por envenenamento ( história. Como já discutido anteriormente, para a compreensão desse emoji como metáfora geralmente são necessários processos cognitivos mais complexos. Mesmo 
tendo o sentido metafórico do pictograma apresentado na lista fornecida no final da obra, em sua primeira aparição, ele vem acompanhado do signo verbal correspondente: "[...]That means dead. " (“[...] significa morto. (SHAKESPEARE; CARBONE, 2015, p. 5).

Danesi (2017, p. 88) também destaca que o fenômeno dos emojis revela que as escritas fonética e pictográfica estão cada vez mais se fundindo para produzir uma linguagem híbrida. Na realidade, essa junção data dos primórdios da civilização. A escrita hieroglífica egípcia, por exemplo, em um estágio anterior à sua substituição pela escrita alfabética, passou a empregar o princípio de rébus, ou seja, o uso dos pictogramas para representar sons (EVANS, 2017, p. 166). Nesse caso, as figuras deixam de ser ideogramas e se tornam fonogramas. Essa conexão entre o visual e o auditivo pode ser relacionada ao fenômeno de transmodalidade icônica discutido por Elleström. Para o teórico, a representação icônica possui uma escala que vai do monomodal ao transmodal e ao cognitivo (fraca semelhança material, espaçotemporal e sensorial). Na obra de Carbone, é possível identificar dois tipos de transmodalidade visual-auditiva. $\mathrm{O}$ primeiro grupo refere-se à relação entre símbolos verbais visuais e fenômenos sonoros. É a convenção que sustenta a iconicidade, ou seja, a semelhança é estrutural e estilizada. Na cena onde Laerte procura por Ofélia, ele pergunta: “Ophelia!! My sister. Where r u?” (Ofélia!! Minha irmã. Onde vc está?”) (SHAKESPEARE; CARBONE, 2015, p. 77). Observa-se que os signos "r" e "u" representam dois objetos sonoros /ar/ e /ju:/. Os interpretantes resultantes tornam-se signos auditivos de dois outros objetos (are e you). Um outro exemplo desse cruzamento de fronteiras sensoriais em signos verbais ocorre logo em seguida, quando Laerte escreve "NO NO NO NO NO" (Ibid., p. 78). O uso de maiúsculas (signo visual), como já visto nesta dissertação, é convencionalmente empregado para indicar o aumento no tom de voz e acaba reforçando a natureza transmodal do texto.

O segundo tipo de transmodalidade visual-auditiva ocorre através dos pictogramas. Uma vez que a semelhança entre os emojis e o fenômeno sonoro também é estrutural, assim como os signos verbais do exemplo acima, eles são

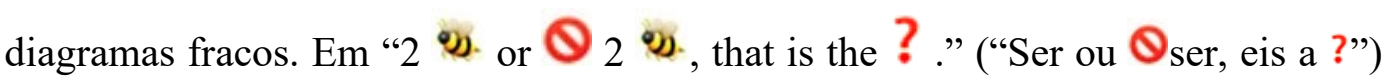
(SHAKESPEARE; CARBONE, 2015, p. 42), Carbone usa o emoji "abelha" e o 
algarismo 2 como signos relacionais, isto é, a relação entre os signos e os objetos produzem interpretantes (signo mental correlato) que se tornam signos auditivos de objetos cognitivos (be e to) (MARTINS; SAGRES, 2020, p. 43).

Um outro exemplo do imbricamento das fronteiras visuais e auditivas é o emoji "relógio de pulso". Nas seis vezes em que o pictograma aparece no texto adaptado, a sua interpretação envolve uma mudança no modo sensorial (do visual para o auditivo). $\mathrm{O}$ interpretante produzido pelo signo visual se transforma, de acordo com o contexto, em representamens auditivos relacionados a diferentes objetos cognitivos (observar, tomar cuidado com e vigiar), que gerarão um novo interpretante. Na mensagem abaixo, por exemplo, o relógio expressa a sugestão de Hamlet para se observar o enterro a fim de descobrir o que está acontecendo.

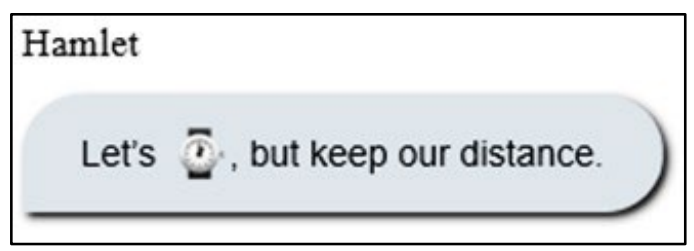

Figura 42 - Sentido pelo contexto ${ }^{104}$

Fonte: SHAKESPEARE; CARBONE, 2015, p. 89

Essa passagem do visual para o auditivo parece ser um outro recurso para destacar a oralidade das mensagens do aplicativo e, de certo modo, reforçar a conexão com a mídia teatro (atual e do século XVI). Como Hamlet claramente destacou, o público do teatro elisabetano ouvia peças (II.ii.472).

Observa-se, então, que o uso de emojis e de outros recursos visuais não é empregado na adaptação apenas como uma forma de atrair crianças e jovens. Esses pictogramas são constituintes do processo comunicativo e, como tal, contribuem para a construção e significação da mensagem. Os elementos visuais, aurais e cinésicos favorecem conexões entre a obra de Carbone e a peça de Shakespeare que a linguagem verbal escrita sozinha não é capaz de estruturar. É essa capacidade de se valer de diferentes características midíaticas e de transitar por diferentes modalidades semióticas que parece permitir que o Bardo seja encontrado nas páginas da adaptação.

${ }^{104}$ Hamlet: Vamos 호, mas mantendo a distância. 


\section{Conclusão}

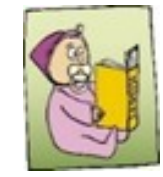

Ainda hoje são comuns desaprovações em relação às adaptações, uma vez que muitos esperam encontrar o texto-fonte nas reescritas. Quando se trata de adaptações e traduções de obras de Shakespeare, críticas à ausência do que se costuma denominar "linguagem shakespeariana" são constantes. Contudo, como Julie Sanders (2006, p. 18) destaca, as adaptações podem ter propósitos e intenções distintas e até mesmo opostas, e sua análise não deve se basear na fidelidade em relação à obra de origem, mas no processo de adaptação propriamente dito, ou seja, nos recursos empregados para que os objetivos sejam alcançados de forma criativa e autônoma.

A reescrita analisada nesta dissertação reafirma a natureza multifacetada do processo adaptativo. Nesse novo produto estético e midiático, Courtney Carbone assegura uma continuidade em relação ao texto-fonte e, ao mesmo tempo, através de diferentes estratégias empregadas, imprime a sua voz e a de sua cultura e época. Em termos funcionais, srsly Hamlet surgiu para atender a demanda do mercado editorial em um período em que publicações relacionadas a Shakespeare encontravam-se muito valorizadas. Por se tratar de uma adaptação de um texto literário canônico e estar voltada para o público infantil e juvenil, essa reescrita encontra-se vinculada a dois objetivos principais: i) divulgar e garantir o acesso do público-alvo à peça de Shakespeare e ii) contribuir para a manutenção das obras do dramaturgo nos cânones literários e educacionais. A proposta da adaptação de Carbone também envolve trazer o lúdico para o texto recriado o que, de certa forma, resgata uma função essencial da dramaturgia shakespeariana. Contudo, srsly Hamlet não se trata apenas de uma atualização, transposição ou simplificação de tramas e elementos narrativos, mas uma reinterpretação do conjunto de características que formam uma imagem consensual de Shakespeare e suas obras. Tais características englobam não só uma linguagem dinâmica, que mistura arcaísmos com neologismos, qualidades poéticas e uma imagética forte, mas 
também o contexto histórico e social, o ambiente teatral e o tipo de engajamento do público elisabetano.

A obra srsly Hamlet não pode ser vista apenas como um meio de distribuição autônomo do texto do Bardo para novas audiências, mas como um representamen de um Shakespeare que rompe com a imagem associada a um autor erudito, de difícil compreensão e quase mítico. No Hamlet de Carbone, encontra-se um Shakespeare em sintonia com sua época e seu público. Os eufemismos, simplificações, expansões (verbais e imagéticas) ou cortes na adaptação são provenientes da visão de literatura voltada para leitores não adultos e do gênero selecionado (chat) e, não, de uma concepção idealizada da obra shakespeariana. Alguns temas, como a sexualidade, foram abordados de forma mais suave ou superficial, a fim de tornar a obra compatível com a faixa etária. Outros (o papel feminino, por exemplo) foram parcialmente ampliados para adequá-los às demandas da sociedade atual. Em nenhum dos casos, parece ter havido uma preocupação em perpetuar a sacralização do texto do dramaturgo inglês.

A pesquisadora Lucia Santaella destaca que a concepção de signo de Peirce é abrangente e que, segundo ele, o signo verbal pode englobar, por exemplo, um livro ou uma biblioteca (SANTAELLA, 2005, p. 278). Dentro dessa visão de um texto como um signo peirceano, creio que seja viável concluir que a obra de Carbone não é um ícone puro, ou seja, uma quase-peça shakespeariana. Para ser um ícone puro teria que ser uma réplica do próprio Hamlet do Bardo. A obra também não pode ser considerada simplesmente um símbolo, porque a interpretação da relação entre o texto-fonte e a adaptação não é habitual ou convencional, pelo contrário, a autora quebra a regularidade ao trazer novas mídias e camadas de sentido para o texto de Shakespeare. Não considero também que a adaptação seja somente indicial, pois, embora haja uma relação de contiguidade entre as duas obras (efeito exercido pela peça na adaptação), essa conexão não é objetiva, isto é, ela não pode ocorrer sem a interpretação do leitor. A análise realizada me permite concluir que srsly Hamlet apresenta aspectos icônicos, indiciais e simbólicos, e a combinação dessas diferentes dimensões é que possibilita a criação dos diferentes níveis de significação.

A dimensão indicial está presente no fato de que o texto de Carbone é afetado pelo texto shakespeariano e, por isso, oferece informações sobre a peça de 
Shakespeare. A função indicial também se encontra nas referências à mídia teatro. Em ambos os casos, como já destaquei, a relação indicial não é natural, isto é, depende de conhecimentos culturais e/ou prévios. Acredito que os aspectos simbólicos se encontram no próprio uso do código verbal (simbólico em relação ao objeto) e no ponto de vista cultural apresentado (símbolo da cultura contemporânea digital). Considero, no entanto, que a adaptação seja predominantemente uma unidade metafórica constituída por diferentes relações de paralelismo. Os itens que constituem uma dessas relações são a peça de Shakespeare (objeto cognitivo e signo), a interpretação de Carbone (interpretante que gera novo signo hipoicônico) e os pontos de comparação. Outro elo é formado pelas mídias que parecem estar presentes na adaptação, ou seja, o livro de Carbone (signo) e o aplicativo de mensagens (objeto), e seus pontos de semelhança. A partir desses vínculos que constituem a metáfora são construídos novos sentidos e imagens de Shakespeare e de Hamlet.

Ao funcionar como metáfora, somente alguns pontos de semelhança caracterizam a intermidialidade da obra adaptada. A iconicidade, nesse caso, é modal, não funcional. As duas mídias (material e representação) em srsly Hamlet compartilham, virtual ou fisicamente, traços modais pré-semióticos e semióticos, mas por serem mídias técnicas com caráteres diferentes, a sua capacidade de exibição dos conteúdos é distinta. Dessa correlação, no entanto, criam-se significações e símbolos. A natureza contemporânea, a capacidade de mudança e de dinamicidade na construção dos significados e a valorização da comunicação e da oralidade são, assim, agregados ao simulacro shakespeariano.

Quero destacar que a natureza multimodal e intermidiática da obra de Carbone não só estabelece um elo com o mundo digital, mas também insere personagens e leitores no teatro de Shakespeare. A mistura da linguagem verbal, dos emojis e de fotografias e a escolha do leiaute compõem o sentido de srsly Hamlet e trazem para esse texto impresso os gestos, as expressões faciais e a fluidez espacial não só característicos da plataforma de mensagens, mas também essenciais nas peças teatrais. Como observa a pesquisadora romena Monica Matei-Chesnoiu (2017, p. 61), o texto shakespeariano era encenado “em teatros com cenários não 
ilusionistas, as peças de Shakespeare criavam o espaço através do movimento, linguagem, gestos e vestuário" ${ }^{105}$.

O paralelismo entre os dois textos literários, por outro lado, revela o espelhamento em termos de trama e elementos da narrativa, mas, ao mesmo tempo, gera um Shakespeare capaz de agradar seu público/leitor, discutir valores atuais, se comunicar com os seus contemporâneos e de manusear as linguagens (verbal e visual) de forma lúdica e criativa. Enfim, um Shakespeare que não tem medo de arriscar. Posso afirmar, então, que o Shakespeare e o Hamlet da era elisabetana não desapareceram em srsly Hamlet. Eles foram ressignificados em novos espaços, códigos e estruturas discursivas. Dessa forma, Carbone oferece a seus leitores a possibilidade de vislumbrar como Shakespeare poderia ter escrito Hamlet caso fosse um autor estadunidense contemporâneo.

Através do uso do que pode se chamar de uma linguagem digital, onde o verbal, o visual e o auditivo se imbricam, e da criação de pontes entre mídias diferentes para que experiências distintas possam ser somadas às fornecidas pelos textos linguísticos e pictográficos, Carbone recria o texto-fonte e propicia não só o diálogo de Shakespeare com os jovens norte-americanos, mas também o contato com diferentes leitores de diferentes culturas e gerações. A imortalidade de Shakespeare e de sua obra reside aí. Como o tradutor e autor Rodrigo Lacerda (2015, p. 10) ressalta, é "[i]mpossível ser fiel ao espírito da peça sem tocar a alma do público atual".

No início desta dissertação questionei o que srsly Hamlet poderia trazer de novo para os estudos shakespearianos. Em sua criação, Carbone renova o encanto de Shakespeare através de novos formatos e códigos. A inovação não reside apenas no fato de fazer uso de um gênero discursivo contemporâneo (mensagens digitais), onde palavra e imagem se complementam e sobrepõem na construção de sentidos. O papel da estrutura intermidiática na significação da obra agrega novas experiências de leitura e de engajamento ao universo do Bardo. A representação de uma mídia virtual em um texto intersemiótico vai além da narrativa e abre espaço para o ambiente teatral e a arte da encenação. Tal fato não só traz características únicas do mosaico multimodal e multimidiático da dramaturgia shakespeariana para

\footnotetext{
105 "Performed in theatres featuring non-illusionistic scenery, Shakespeare's plays establish location through movement, language, gesture, and costume."
} 
as adaptações impressas, mas também pode suscitar novos debates sobre as fronteiras entre as mídias.

Concluo destacando que a magia alimentada pela imaginação e pela ousadia de Shakespeare e dos reescritores de sua obra não pode ser investigada de forma restrita ou tendo por base apenas uma área do conhecimento. Os diferentes Shakespeares e Hamlets que transitam pelo mundo demandam, cada vez mais, abordagens interdisciplinares para que as diversas camadas de sua construção sejam alcançadas. Espero, portanto, que esta dissertação possa contribuir para uma ampliação da discussão nos estudos da adaptação e dos intermidiáticos não só sobre literatura infantil e juvenil impressa, mas também sobre o papel provocador de Shakespeare na abertura de possibilidades de diálogo entre diferentes disciplinas e com a contemporaneidade. 


\section{7 \\ Referências bibliográficas}

AGRELA, Lucas. Este é o hábito mais comum dos brasileiros no WhatsApp. Exame, [São Paulo], 8 out. 2019. Disponível em: https://exame.com/tecno logia/este-e-o-habito-mais-comum-dos-brasileiros-no-whatsapp/. Acesso em: 17 jan. 2020.

AMORIM, Marcel Alvaro. Da tradução intersemiótica à teoria da adaptação intercultural: estado da arte e perspectivas futuras. Itinerários, São Paulo, n. 36, p.15-33, jan. /jun. 2013.

ARIÈS, Philippe. História social da criança e da família. 2. ed. Tradução: Dora Flaksman. Rio de Janeiro: Guanabara, 1986.

THE AUTHOR NEWSLETTER TEAM \& THE PENGUIN RANDOM HOUSE LEGAL DEPARTMENT. Protecting Our Authors' Right to Freedom of Speech and Expression. [New York], Apr. 2018. Disponível em: https://authornews.penguinrandomhouse.com/protecting-our-authors-rightto-freedom-of-speech-and-expression/ Acesso em: 30 out. 2019.

BASSNETT, Susan. The translation turn in cultural studies. In: BASSNETT, Susan; LEFEVERE, André. Constructing cultures: essays on literary translation. Clevedon: Multilingual Matters, 1998. p. 123-140.

BASSNETT, Susan. Translation Studies. $3^{\text {rd }}$ ed. London: Routledge, 2002.

BASSNETT, Susan; LEFEVERE, André. Introduction: Proust's grandmother and the Thousand and One Nights: The 'Cultural Turn' in Translation Studies. In: BASSNETT, Susan; LEFEVERE, André. Translation, History and Culture. London: Cassell, 1990.

BBC. Bard is Millennium Man. BBC News, [UK], Jan. 1, 1999. Disponível em: http://news.bbc.co.uk/2/hi/uk news/245752.stm. Acesso em: 26 out. 2019.

BLOOM, Harold. The Anatomy of Influence: Literature as a Way of Life. USA: Yale University Press, 2011.

BRITLAND, Karen. "My God! Madam, there must be only one black figure in this play": Hamlet, Ophelia, and the Romantic Hero. In: ORTIZ, Joseph M. (ed). Shakespeare and the Culture of Romanticism. Surrey: Ashgate, 2013. p. 51-74.

BURT, Richard. "Introduction: To e- or not to e-? Disposing of Schlockspeare in the Age of Digital Media". In: BURT, Richard (ed.). Shakespeare after mass media. New York: PALGRAVE, 2002. p. 1-32. 
BLOOM, Harold. The Western Canon: the books and schools of the ages. New York: Hartcourt Brace \& Company, 1994.

BURT, Richard. Hamlet's Hauntographology: Film Philology, Facsimiles and Textual Faux-rensics. In: CARTMELL, Deborah (ed.). A Companion to Literature, Film and Adaptation. West Sussex: Wiley-Blackwell, 2012. p. 216-240.

CAMATI, Anna Stegh. Intermedial performance aesthetics in Patrícia Fagundes' A Midsummer Night's Dream. Aletria, Belo Horizonte, v. 23, n. 3, p. 141-156, set./dez. 2013. Disponível em: http://www.periodicos. letras.ufmg.br/index.php/aletria/article/view/4942. Acesso em: 21 jan. 2020.

CAMATI, Anna Stegh. Sonho de uma noite de verão: a inscrição do processo de adaptação cênica no texto shakespeariano. Revista de Letras, São Paulo, v.51, no 1, p. 127-141, jan./jun. 2011. Disponível em: https://periodicos.fclar.unesp.br/letras/article/view/5109. Acesso em: 23 jan. 2020.

CHEN, Tom S. Challenges in Building a Culture-Centric Web Site. In: RAHMAN, Hakikur (ed.) Selected Readings on Global Information Technology: Contemporary Applications. Hershey: Information Science Reference, 2009. p. 230-244.

CHICAGO SHAKESPEARE THEATER. Shakespeare 400 Chicago, 16162016. Chicago, 2016. Disponível em: http://www.shakespeare 400chicago.com/events.html. Acesso em: 28 out. 2019.

CLEMENT, J. U.S. number of WhatsApp users 2019-2023. Statista, New York, Aug. 9, 2019. Disponível em: https://www.statista.com/statistics/5582. Acesso em: 17 jan. 2020.

CRYSTAL, David. 'Think on my Words': Exploring Shakespeare Language. New York: Cambridge, 2008.

DANESI, Marcel. The Semiotics of Emoji: the rise of visual language in the age of internet. London: Bloomsbury, 2017. (Bloomsbury Advances in Semiotics).

DANTAS, Miguel. "Zero", "OK", ou "supremacia branca"? A história de um gesto "roubado" pela extrema-direita. [Clube]P, ano XXX, n. 10.804, Lisboa, 21 nov., 2019. Disponível em: https://www.publico.pt/2019/11/21/ politica/noticia/policia-usa-gestos-odio-conotados-extremadireita-durantemanifestacao-1894615. Acesso em: 12 fev. 2020.

DERRIDA, Jacques. Essa estranha instituição chamada literatura: uma entrevista com Jacques Derrida. Tradução: Marileide Dias Esqueda. Belo Horizonte: Editora UFMG, 2014. 
DONALDSON, Alasdair. All the World's: How Shakespeare is viewed around the globe and the role his work can play to support the UK's soft power. Manchester: British Council, 2016. Disponível em: https://www.britishcouncil.org/sites/default/files/all the worlds.pdf. Acesso em: 27 out. 2019.

ELLESTRÖM, Lars. Media Transformation: The Transfer of Media Characteristics Among Media. Hampshire: Palgrave MacMillan, 2014. Ebook.

ELLESTRÖM, Lars. Adaptation and Intermediality. In: LEITCH, Thomas. The Oxford Handbook of Adaptation Studies. New York: Oxford University Press, 2017a. p. 509-526.

ELLESTRÖM, Lars. Adaptations within the field of media transformations. In: BRUHN, Jørgen, GJELSVIK, Anne and HANSSEN, Eirik Frisvold (ed.). Adaptation Studies: New Challenges, New Directions. London: Bloomsbury, 2013a. p. 113-132.

ELLESTRÖM, Lars. Bridging the gap between image and metaphor through cross-modal iconicity. In: ZIRKER, Angelika et al (ed.). Dimensions of Iconicity. Amsterdam: John Benjamins Publishing Company, 2017b. p. 167-190.

ELLESTRÖM, Lars. Iconicity as meaning miming meaning and meaning miming form. CONRADIE, Jac. et al. (eds). Signergy 9. Amsterdam: John Benjamins Publishing Company, 2010a. p. $73-100$.

ELLESTRÖM, Lars. Identifying, Construing, and Bridging over Media Borders. Scripta Uniandrade, Curitiba, v. 16, n. 3, p. 15-30, 11 nov. 2018. Disponível em: https://uniandrade.br/revistauniandrade/index.php/Scripta Uniandrade/article/view/1162/926. Acesso em: 08 set. 2019.

ELLESTRÖM, Lars. The Modalities of Media: A Model for Understanding Intermedial Relations. In: ELLESTRÖM, Lars (ed.). Media Borders, Multimodality and intermediality. Hampshire: Palgrave Macmillan, 2010b. p. 11-48.

ELLESTRÖM, Lars. Um modelo de comunicação centralizado na mídia. Tradução de Rafael Eisinger Guimarães. In: DOMINGOS, Ana Cláudia Munari, KLAUCK, Ana Paula \& MELLO, Glória Maria Guiné (org.). Midialidade: ensaios sobre comunicação, semiótica e intermidialidade. Porto Alegre: EDIPUCRS, 2017c. p. 15-48. (Série NUPECC; 19).

ELLESTRÖM, Lars. Spatiotemporal aspects of iconicity. In: ELLESTRÖM, Lars, FISCHER, Olga and Ljungberg, Christina (ed.). Iconic Investigations, v. 12. Amsterdam: John Benjamins Publishing Company, 2013b. p. 95-117. (Iconicity in Language and Literature). 
ELLESTRÖM, Lars. A theoretical approach to media transformations. In: TORO, Alfonso (ed.). TRANSLATIO: Transmedialite et transculturalite en litterature, peinture, photographie et au cinema. Paris: L'Harmattan, 2013c. p. 97-105.

ELLESTRÖM, Lars. Transfer of Media Characteristics Among Dissimilar Media. Palabra Clave, vol. 20, no.3. Bogotá: Universidad de La Sabana, Sept. 2017d. p. 663-685. Disponível em: https://palabraclave.unisabana. edu.co/index.php/palabraclave/article/view/6937/pdf. Acesso em: 19 out. 2019.

EPSTEIN, Connie C. Children's Book Publishing in the USA. In: HUNT, Peter; RAY, Sheila (ed.). International Companion Encyclopedia of Children's Literature. London: Routledge, 2005. p. 471 - 477. E-book.

ESTILL, Laura. Was Shakespeare as popular in his own time as he is now? Voices Magazine, [UK], 09 June 2015. Disponível em: https://www.british council.org/voices-magazine/was-shakespeare-popular-his-own-time-henow. Acesso em: 26 maio 2019.

ESTILL, Laura; JOHNSON, Eric. Fun international facts about Shakespeare. Voices Magazine, [UK], 19 Mar. 2015. Disponível em: https://www.britishcouncil.org /voices-magazine/fun-international-facts-abo ut- shakespeare. Acesso em 26 out. 2019

EVANS, Vyvyan. The Emoji Code: The Linguistics Behind Smiley Faces and Scaredy Cats. New York: Picador, 2017.

EVEN-ZOHAR, Itamar. Polysystem Studies. Poetics Today, Durham, v. 11, n. 1, p. 1-268,1990.

EWBANK, Inga-Stina. Hamlet and the Power of Words. In: PRICE, Joseph G. Hamlet: Critical Essays. London: Routledge, 2014. p. 417-449. E-book.

FILIPSKI, Soren. Sources of Shakespeare: The Norse Hamlet. [S. I.]: Hythloday Press, 2013. E-book.

FISCHLIN, Daniel; FORTIER, Mark (ed.). Adaptations of Shakespeare: a critical anthology of plays from the seventeenth century to the present. London: Routledge, 2000.

FOLLOWS, Stephen. How many movies based on Shakespeare plays are there? Film data blog. [s.I.], Mar. 14, 2017. Disponível em: https://stephenfollows.com/movies-based-on-shakespeare-plays/. Acesso em: 01 set. 2019.

FREDNER, Erik. How many novels have been published in English? (An Attempt). Stanford Literary Lab. Stanford, Techne, 2016. Disponível em: 
https://litlab.stanford.edu/ how-many-novels-have-been-published-in-englis h-an-attempt/\# ftn10. Acesso em: 02 maio 2019.

GRADY, Hugh. Shakespeare criticism, 1600-1900. In: DE GRAZIA, Margaret; WELLS, Stanley (ed.). The Cambridge Companion to Shakespeare. Cambridge: Cambridge University Press, 2001. p. 265-278.

GRAVELLS, Jane. Semiotics and Verbal Texts: How the News Media Construct a Crisis. London: Palgrave Macmillan, 2017.

GREENBLATT, Stephen. Will in the world: how Shakespeare became Shakespeare. London: Vintage, 2004.

HALL, Edward T. Beyond Culture. New York: Anchor Books, 1989.

HALL, Edward T. The silent language. New York: Doubleday \& Company, 1959.

HALL, Edward T.; HALL, Mildred R. Understanding cultural differences: Germans, French and Americans. Boston: Intercultural Press, 1990.

HAPPÉ, Peter. Theatres and Companies: The Context of the Professional Stage - James Burbage and John Lyly. In: BLOOM, Harold (ed.). Elizabethan Drama. New York: Chelsea House Publishers, 2004. p. 27-45. (Bloom's Period Studies).

HARRIS, Jonathan Gil. Shakespeare and Literary Theory. Oxford: Oxford University Press, 2010. (Oxford Shakespeare Topics).

HATELEY, Erica. Shakespeare's in Children's Literature: Gender and Cultural Capital. New York: Routledge, 2009. E-book.

HATTAWAY, Michael. Elizabethan Popular Theatre: Plays in Performance. London: Routledge \& Kegan Paul, 1982.

HAWKES, Terence. Meaning by Shakespeare. London: Routledge, 1992.

HELIODORA, Barbara, pseud. Os Teatros No Tempo De Shakespeare. In: LEÃO, Liana de Camargo Leão; SANTOS, Marlene Soares dos (org.). Shakespeare, sua época e sua obra. Curitiba: Editora Beatrice, 2008. p. 65-79.

HERMANS, Theo. Introduction: Translation Studies and a new paradigm. In: HERMANS, Theo (ed.). The Manipulation of Literature: studies in literary translation. New York: Routledge, 2014. p. 7-15.

HERMANS, Theo. Translation in systems: descriptive and systemic approaches explained. Manchester: St. Jerome Publishing, 1999. 
HOAD, T. F. (ed.). Oxford Concise Dictionary of English Etymology. Oxford: OUP, 1996.

HOLZBERG, William G. Introduction. In: HOLZBERG, William G, WALDECK, Peter B. (ed.). Perspectives on Hamlet: collected papers of the Bucknell-Susquehanna Colloquium on Hamlet held at Bucknell and Susquehanna Universities, April 27 and 28, 1973. Cranbury: Associated University Presses, 1975. p. 15-25.

HUNT, Marvin W. Looking for Hamlet. New York: Palgrave Macmillan, 2007.

HUTCHEON, Linda; O'FLYNN, Siobhan. A theory of Adaptation. $2^{\text {nd }}$ ed. New York: Routledge, 2013. E-book.

JAKOBSON, Roman. Closing Statement: Linguistics and Poetics. In: SEBEOK, Thomas A. (ed.). Style in Language. Massachusetts: The Technology Press of Massachusetts Institute of Technology, 1960. p. 350377.

JONES, Chuck. What the Teen Survey On iPhone, iPad And Watch Means for Apple. Forbes, Jersey City, Oct. 8, 2014. Disponível em: https://www.forbes.com/sites/chuckjones/2014/10/08/what-does-teen-surv ey-on-iphone-ipad-and-watch-mean-for-apple/\#1f66a953a770. Acesso em: 02 nov. 2019.

JONES, Jonathan. Emoji is dragging us back to the dark ages - and all we can do is smile. The Guardian, U.K., international ed., 28 May 2015. Disponivel em: https://www.theguardian.com/artanddesign/jonathanjones blog/2015/may/27/emoji-language-dragging-us-back-to-the-dark-agesyellow-smiley-face. Acesso em: 02 nov. 2019.

JONES, Steven Swann. The Fairy Tale: The Magic Mirror of the Imagination. New York: Routledge, 2002. E-book.

KAVANAGH, James H. Shakespeare in ideology. In: DRAKAKIS, John (ed.). Alternative Shakespeares. $2^{\text {nd }}$ ed. London: Routledge, 2002. p. 146 -168 .

KOPF, Dan. What is Shakespeare's most popular play. Priceonomics, San Francisco, 2016. Disponível em: https://priceonomics.com/what-isshakespeares-most-popular-playl. Acesso em: 22 jan. 2020.

LACERDA, Rodrigo. Hamlet ou Amleto?: Shakespeare para jovens curiosos e adultos preguiçosos. Rio de Janeiro: Zahar, 2015.

LAJOLO, Marisa \& ZILMERMAN, Regina. Literatura infantil brasileira: uma nova / outra história. Curitiba: PUCPress, 2017. 
LANIER, Douglas. Shakespeare ${ }^{\mathrm{TM}}$ : myth and biographical fiction. In: SHAUGHNESSY, Robert (ed.). The Cambridge Companion to Shakespeare and Popular Culture. Cambridge: Cambridge University Press, 2007. p. 93-113.

LEFEVERE, André. Translation, Rewriting and the Manipulation of Literary Fame. New York: Routledge, 2017. E-book.

LEFEVERE, André. Why waste our time on rewrites? The trouble with interpretation and the role of rewriting in an alternative paradigm. In: HERMANS, Theo (ed.). The Manipulation of Literature: studies in literary translation. New York: Routledge, 2014. p. 215-243.

LEVINE, Lawrence W. William Shakespeare and the American People: A Study in Cultural Transformation. The American Historical Review, [U.S.A.], vol. 89, issue 1, Feb. 1984. p. 34-66.

LYNCH, Kevin. William Shakespeare turns 450 - Ten startling Great Bardthemed world records. Guiness World Records, London, 2014. Disponível em:https: //www.guinnessworldrecords.com/news/2014/4/william- shakesp eare-turns-450-ten-startling-great-bard-themed-world-records-56. Acesso em: 22 jan. 2020.

MANGAN, Michael. A preface to Shakespeare's tragedies. New York: Routledge, 2014.

MARTINS, Marcia do Amaral Peixoto. A instrumentalidade do modelo descritivo para a análise de traduções: $O$ caso dos Hamlets brasileiros. 1999. Tese (Doutorado em Comunicação e Semiótica) - PUC-São Paulo, São Paulo, 1999. Disponível em: http://dbd.puc-rio.br/ shakespeare/pdfs/hamlets brasileiros.pdf. Acesso em: 19 dez. 2019.

MARTINS, Marcia do Amaral Peixoto. Reescritas de peças de Shakespeare para o público jovem: a série Mangá Shakespeare. Cadernos de Tradução, [Florianópolis], v. 2, n. 34, jul./dez. 2014, p. 61-84. Disponível em: $\quad$ https://periodicos.ufsc.br/index.php/traducao/article/view/21757968.2014v2n34p61. Acesso em: 23 jan. 2020.

MARTINS, Marcia do Amaral Peixoto. A tradução dos jogos de palavras shakespearianos: o caso de A Megera Domada. In: CAMATI, Anna Steigh; MIRANDA, Célia Arns de (org.). Shakespeare sob múltiplos olhares. 2. ed. Curitiba: Ed. UFPR, 2016. p. 287-314.

MARTINS, Marcia do Amaral Peixoto; SAGRES, Ofélia da Conceição Machado. Shakespeare visita o mundo virtual: o uso de Emojis em reescritas de suas peças. Cadernos de Tradução, [Florianópolis], v. 40, n. 1, p. 34-53, 2020. Disponível em: ahttps://periodicos.ufsc.br/index.php/ traducao/article/view/2175-7968.2020v40n1p34. Acesso em: 25 jan. 2020. 
MATEI-CHESNOIU, Monica. Space, Place, and Shifting Worlds in Shakespeare and Cervantes. In: ACTA IASSYENSIA COMPARATIONES, special issue: 400 years with Shakespeare \& Cervantes. Universitatea Alexandru Ion Cuza, 2017. p. 61-71. Disponível em: http://literatura comparata.ro/Site Acta/issues/aic-20s/07 20s Chesnoiu.pdf . Acesso em: 19 dez. 2019.

McLUSKIE, Kate, RUMBOLD, Kate. Cultural value in twenty-first century England: The case of Shakespeare. Manchester: Manchester University Press, 2014. E-book.

MEDEIROS, Fernanda Teixeira. Shakespeare na ficção brasileira contemporânea: A Tempestade (1611) em Onze (1995) de Bernardo Carvalho. In: SALGUEIRO, Maria Aparecida Andrade (org.). Feminismos, identidades, comparativismos: vertentes nas literaturas de língua inglesa. Vol. VIII. Rio de Janeiro: Letra Capital, 2010. p. 41-68.

MILLIOT, Jim. Ranking 2015 Children's Bestsellers. Publishers Weekly, [s.I.], 29 Jan. 2016a. Disponível em: https://www.publishersweekly.com/ pw/by-topic/childrens/childrens-industry-news/article/69287-children-sbestsellers-2015.html. Acesso em: 22 out. 2019.

MILLIOT, Jim. The Hot and Cold Book Categories of 2015. Publishers Weekly, [s.I.], 14 Jan. 2016b. Disponível em: https://www.publishers weekly.com/pw/by-topic/industry-news/bookselling/article/69138-the-hotand-cold-book-categories-of-2015.html. Acesso em: 22 out. 2019.

NGA CENTER; CCSSO. The Common Core State Standards for English Language Arts \& Literacy in History / Social Studies, Science, and Technical Subjects. Washington D.C.: National Governors Association Center for Best Practices: Council of Chief State School Officers, 2010. Disponível em: http://www.corestandards.org/wp-content/uploads/ELA Standards1.pdf. Acesso em: 28 out. 2019.

NIELSEN. 2015 U.S. Book Industry Year-End Review. New York, May 31, 2016. Disponível em: https://www.nielsen.com/us/en/insights/report/ 2016/2015-us-book-industry-year-end-review/. Acesso em: 28 out. 2019.

O'MELINN, Liam Séamus. The Recording Industry v. James Madison, aka "Publius": The Inversion of Culture and Copyright. SEATTLE UNIVERSITY LAW REVIEW, Seattle, Vol. 35. Iss. 1. 2011. p. 75-133. Disponível em: https://digitalcommons.law.seattleu.edu/sulr/vol35/iss1/2/. Acesso em: 26 out. 2019.

OXFORD UNIVERSITY PRESS. Word of the Year 2015. Oxford Dictionary. [England]: OUP, 2015. Disponível em: https://languages.oup.com/word-of-the-year/2015/. Acesso em: 02 nov. 2019. (Oxford Languages). 
PAVIS, Patrice. Dicionário de Teatro. Tradução sob a direção de J. Guinsberg e Maria Lúcia Pereira. 3. ed. São Paulo: Perspectiva, 2008.

PEIRCE, Charles Sanders. The Essential Peirce: Selected Philosophical Writings, v.2. Edited by the Peirce Edition Project. Bloomington: Indiana University Press, 1998.

PENGUIN RANDOM HOUSE INTERNATIONAL SALES. Srsly Hamlet: part of OMG Shakespeare. [S.I.]: Penguin Random House, [2015?]. Disponível em: vhttp://prhinternationalsales.com/book/?isbn=978055353 5389. Acesso em: 26 out. 2019.

PETERSON, Valerie. The Advantages of Being Published by a Big Five Book Publisher. The Balance Careers. New York: Dec 15, 2018. Disponível em: https://www.thebalancecareers.com/big-five-bookpublisher-279983. Acesso em: 22 out. 2019.

PETERSON, Valerie. The Big 5 Trade Book Publishers. The Balance Careers. New York: May 30, 2019. Disponível em: https://www.thebalancecareers.com/the-big-five-trade-book-publishers-28 00047. Acesso em: 22 out. 2019.

PRONI, Giampaolo et al. Semiotranslation: Peircean Approaches to Translation. In: PETRILLI, Susan (ed.). Translation Translation. Amsterdam: Rodopi, 2003. p. 253-267.

RAJEWSKY, Irina O. Border Talks: The Problematic Status of Media Borders in the Current Debate about Intermediality. In: Elleström, Lars (ed.). Media Borders, Multimodality and Intermediality. Hampshire: Palgrave Macmillan, 2010. p.51-68.

RAJEWSKY, Irina O. Intermediality, Intertextuality, and Remediation: A Literary Perspective on Intermediality. Intermedialités, Montréal, $n^{\circ} 6, p$. 43-64, 2005. Disponível em: http://cri.histart.umontreal.ca/cri/fr/ intermedialites/p6/pdfs/p6 rajewsky text.pdf. Acesso em: 04 set. 2019.

RHTEACHERLIBRARIANS. OMG Shakespeare: classroom activities. [S.I.]: Penguin Random House, [2015?]. Disponível em: https://images.randomhouse.com/promo image/9780553535389 3459.pd f. Acesso em: 19 maio 2019.

RIPPL, Gabriele. Introduction. In: RIPPL, Gabriele (ed.). Handbook of Intermediality: Literature, Image, Sound, Music. Berlin: De Gruyter, 2015. p. 12-77.

SANDERS, Julie. Adaptation and appropriation. London: Routledge, 2006. 
SANTAELLA, Lucia. Matrizes da linguagem e pensamento: sonora, visual, verbal: aplicações na hipermídia. 3 ed. São Paulo: Iluminuras, 2005.

SANTOS, Marlene Soares dos. Shakespeare: as comédias. Belo Horizonte: Tessitura;CEsh, 2016a.

SANTOS, Marlene Soares dos. A Dramaturgia Shakespeariana. In: LEÃO, Liana de Camargo Leão; SANTOS, Marlene Soares dos (org.). Shakespeare, sua época e sua obra. Curitiba: Editora Beatrice, 2008. p. 165-206.

SANTOS, Marlene Soares dos. A narrativa no teatro shakespeariano: Otelo. In: CAMATI, Anna Steigh; MIRANDA, Célia Arns de (org.). Shakespeare sob múltiplos olhares. 2. ed. Curitiba: Ed. UFPR, 2016b. p. 103-118.

SHAKESPEARE, William. A tragédia de Hamlet, príncipe da Dinamarca. Tradução, introdução e notas de Lawrence Flores Pereira. São Paulo: Penguin Classics Companhia das Letras, 2015.

SHAKESPEARE, William. Hamlet: Revised Edition. Edited by Ann Thompson and Neil Taylor. London: Bloomsbury Publishing, 2016. E-book (The Arden Shakespeare Third Series).

SHAKESPEARE, William; CARBONE, Courtney. Srsly Hamlet. New York: Random House, 2015. (OMG Shakespeare series).

SHAVIT, Zohar. Poetics of Children's Literature. Athens: The University of Georgia Press, 1986.

SHAVIT, Zohar. The Historical Model of the Development of Children's Literature. In: NIKOLAJEVA, Maria (ed.). Aspects and Issues in the history of Children's Literature: published under the auspices of the International Research Society for Children's Literature. Westport: Greenwood Press, 1995. p. 27-38. (Contributions to the Study of World Literature, no. 60).

SHAVIT, Zohar. The Notion of Childhood and the Child as Implied Reader (Test Case: "Little Red Riding Hood"). Journal of Research and Development in Education, [Georgia], v. 16, no. 3, Sept 1983, p. 60-67.

SHAVIT, Zohar. Tradução Cultural: Ajustes Ideológicos e de Modelo na Tradução de Literatura Infantil. Tradução: Lia Araujo Miranda de Lima. Belas Infiéis, Brasília, v. 5, n. 3, p. 119-143, 2016. Disponível em: https://periodicos.unb.br/index.php/belasinfieis/article/view/11403/10039. Acesso em: 02 nov. 2019.

SIPONKOSKI, Nestori. Translation under negotiation. The textual interplay of translators and editors in contemporary Finnish Shakespeare translation. 
2014. Monograph (English Studies) - Faculty of Philosophy, University of Vaasa, Vaasa, 2014. (Acta Wasaensia, 304). Disponível em: https:// www.univaasa.fi/materiaali/pdf/isbn 978-952-476-546-6.pdf. Acesso em: 02 nov. 2019.

SHUTTLEWORTH, Mark. Polysystem. In: BAKER, Mona; SALDANHA, Gabriela. Routledge Encyclopedia of Translation Studies. $2^{\text {nd }}$ ed. London: Routledge, 2011.

SMITH, Kyle. Emojis are ruining civilization. New York Post, New York, Oct. 14, 2015. Disponível em: https://nypost.com/2015/10/14/emojis-areruining-civilization/ . Acesso em: 02 de novembro de 2019.

STAM, Robert. Teoria e prática da adaptação: da fidelidade à intertextualidade. Ilha do Desterro, Santa Catarina, $n^{\circ}$ 51, p. 19-53, jul./dez. 2006. Disponível em: https://periodicos.ufsc.br/index.php/ desterro/article/view/2175-8026.2006n51p19/9004. Acesso em: 10 maio 2019.

STERNBERGH, Adam. Smile, You're Speaking EMOJI: The rapid evolution of a wordless tongue. New York Magazine, New York. Nov. 16, 2014. Disponível em: https://nymag.com/intelligencer/2014/11/emojis-rapidevolution.html?mid=facebook nymag\&fbclid=lwAR00v2c-CLo-XVS1W30 YrYA21JKv9LgyCSzAq wltTZt7kW3HnQVpXrk9wE. Acesso em: 23 jan. 2020.

SWIFTKEY. Most-used emoji revealed: Americans love skulls, Brazilians love cats, the French love hearts. Swiftkey.Blog, [s.I.], April 21, 2015. Disponível em: https://blog.swiftkey.com/americans-love-skulls-brazilianslove-cats-swiftkey-emoji-meanings-report/. Acesso em: 02 nov. 2019.

TOCQUEVILLE, Alexis de. A democracia na América: sentimentos e opiniões de uma profusão de sentimentos e opiniões que o estado social democrático fez nascer entre os americanos. Tradução: Eduardo Brandão. São Paulo: Martins Fontes, 2000.

TOURY, Gideon. Descriptive Translation Studies and beyond. Amsterdam: John Benjamins Publishing Company, 1995.

TUNNELL, Michael O.; JACOBS, James S. The Origins and History of American Children's Literature. The Reading Teacher, [s.I.], vol. 67, no. 2, p. 80-86, 2013.

TYMOCZKO, Maria. Enlarging translation, empowering translators. Manchester: St. Jerome Publishing, 2007.

UNICODE. Emoji List, v.13.0. UNICODE Emoji, [USA], 29 Jan. 2020. Disponível em: https://unicode.org/emoji/charts-13.0/emoji-list.html. Acesso em: 16 fev. 2020. 
VIEIRA, Else Ribeiro Pires. A interação do texto traduzido com o sistema receptor: a teoria dos polissistemas. In: VIEIRA, Else Ribeiro Pires (org.). Teorizando e contextualizando a tradução. Belo Horizonte: Faculdade de Letras da UFMG, Curso de Pós-Graduação em Estudos Lingüísticos, 1996. p. 124-137.

WEIMANN, Robert. Author's Pen and Actor's Voice: Playing and Writing in Shakespeare's Theatre. Cambridge: Cambridge University Press, 2000.

WEISER, Benjamin. At Silk Road Trial, Lawyers Fight to Include Evidence They Call Vital: Emoji. The New York Times, New York, vol. CLXIV, n. 56,760, Jan. 28, 2015. Disponível em: https://www.nytimes.com/2015/01/29/nyregion/trial-silk-road-online-blackmarket-debating-emojis.html. Acesso em 02 nov. 2019.

WOLF, Werner. Intermediality Revisitied: Reflections on Word and Music Relations in the Context of a General Typology of Intermediality. In: LODATO, Suzanne M., ASPDEN, Suzanne, BERNHART, Walter (ed.). Essays in Honor of Steven Paul Scher and on Cultural Identity and the Music Stage. Amsterdam: Rodopi, 2002. p. 13-34. (Word and Music Studies 4). 
8

Anexo 1 - Atividades pedagógicas para a série

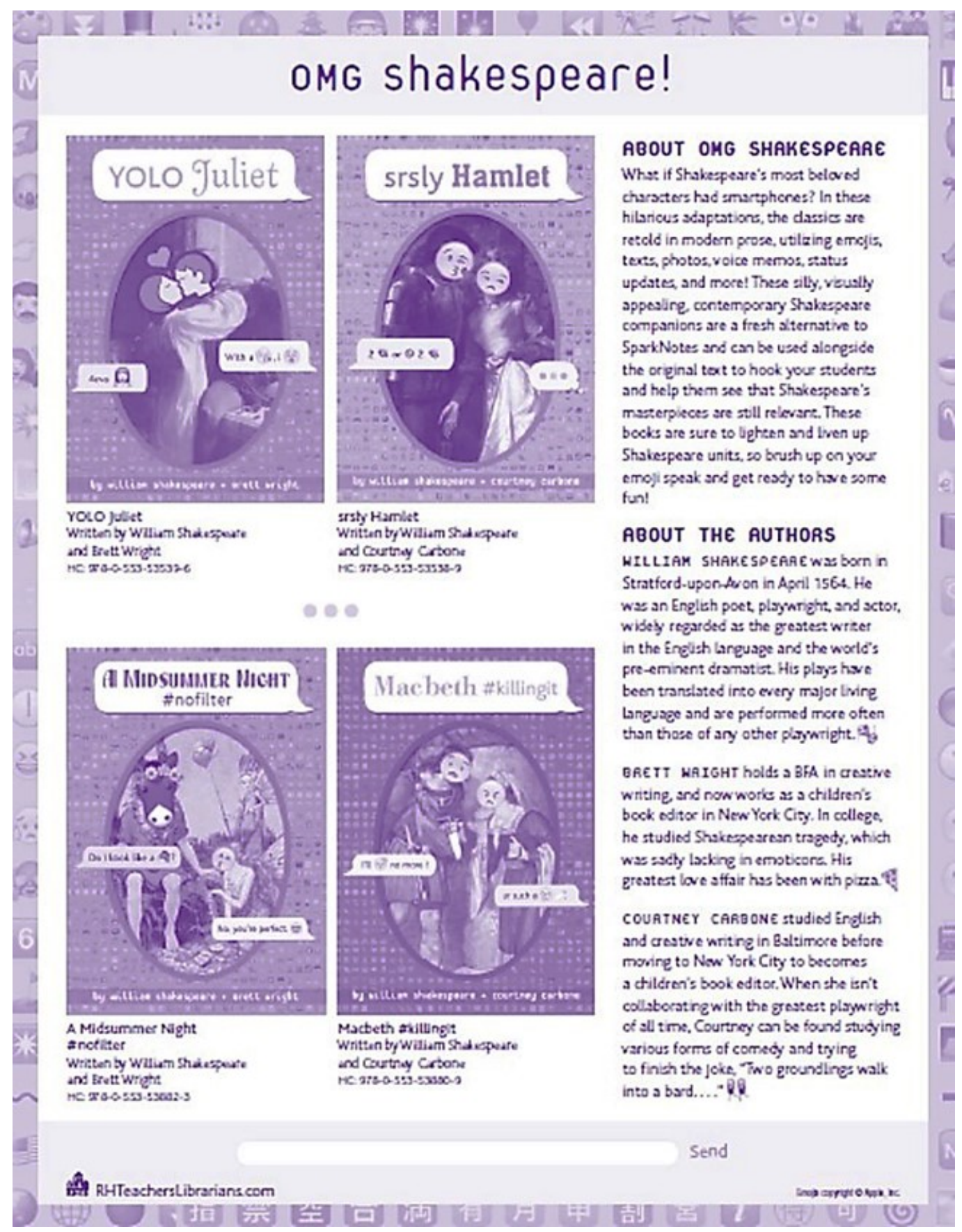




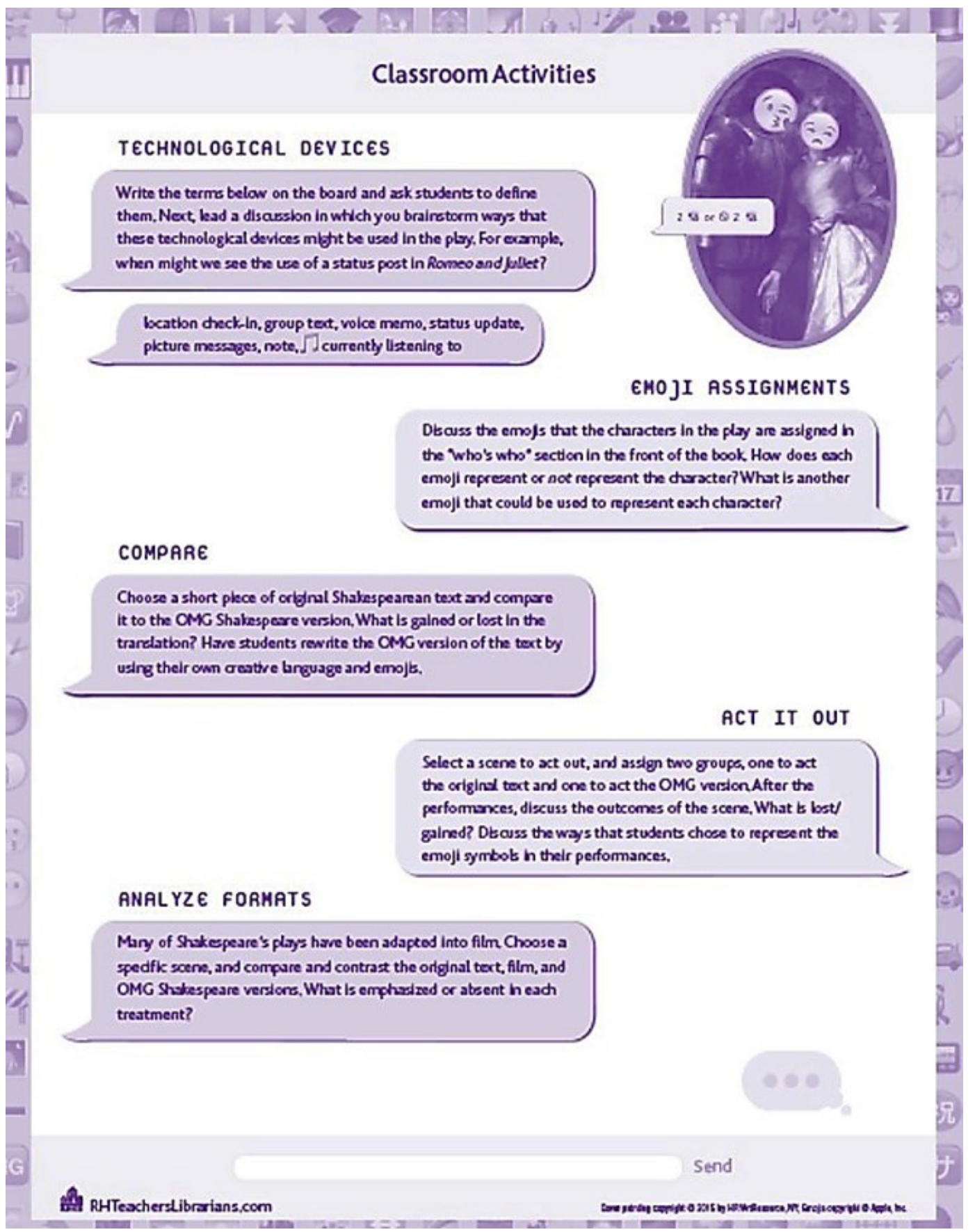




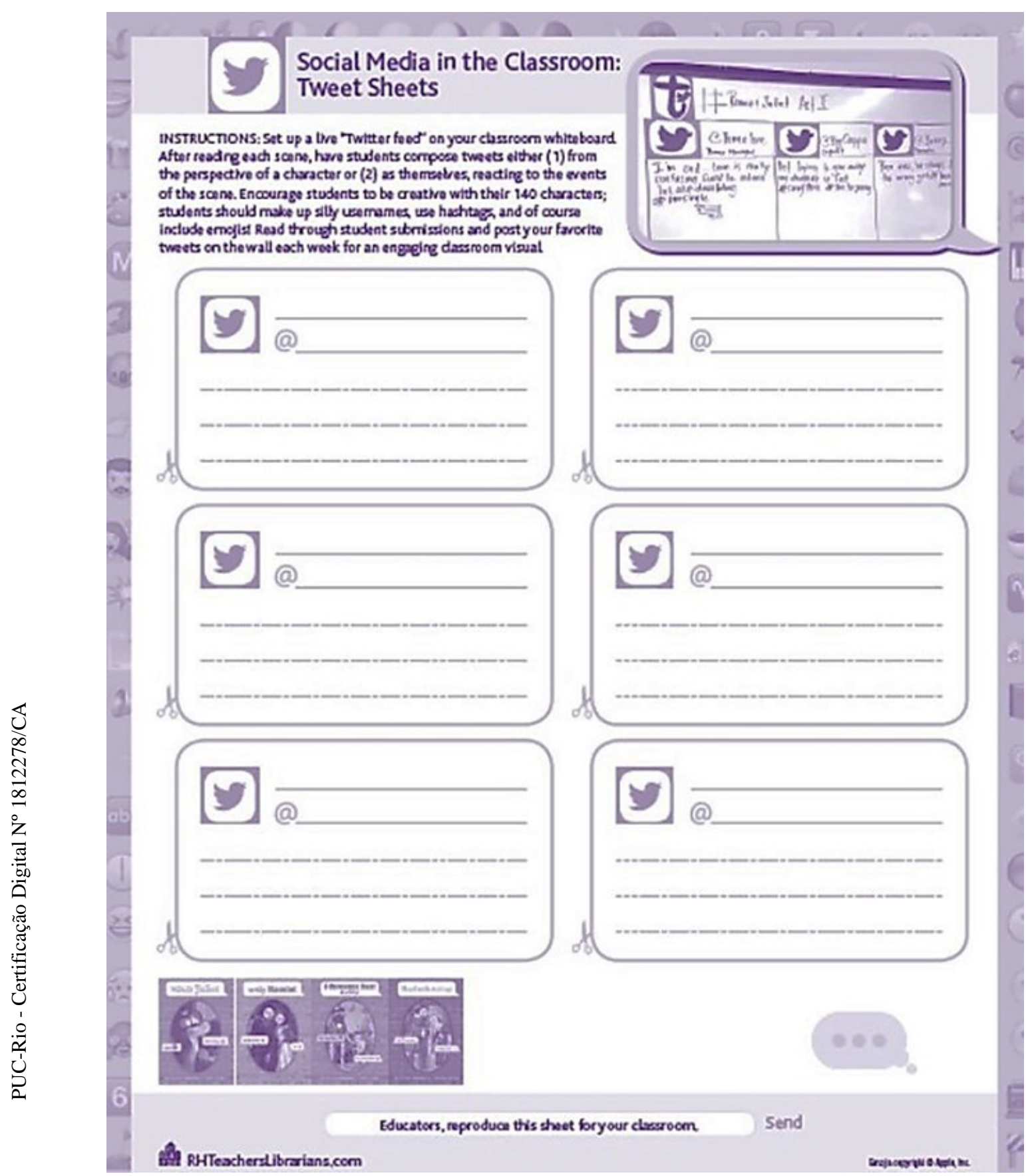

